\title{
Group 4 constrained geometry complexes for olefin (co)polymerisation
}

Thomas J. Williams, Alexander D. H. Smith, Jean-Charles Buffet, Zoë R. Turner and Dermot O'Hare*

Chemistry Research Laboratory, Department of Chemistry, University of Oxford, 12 Mansfield Road, OX1 3TA, UK

Corresponding author: dermot.ohare@chem.ox.ac.uk

Keywords: constrained geometry complexes, (co)polymerisation, olefins, slurry-phase

\begin{abstract}
We report the synthesis and characterisation of eight constrained geometry complexes, with variation of the amido fragment, ansa-bridge, permethylindenyl group, metal centre and initiator groups from the parent complex ${ }^{\mathrm{Me}_{2}} \mathrm{SB}\left({ }^{t \mathrm{Bu}} \mathrm{N}, \mathrm{I}^{*}\right) \mathrm{TiCl}_{2}$. These complexes have been shown to be highly active for slurry-phase ethylene polymerisation when supported on solid polymethylaluminoxane (sMAO), with activities up to $7048 \mathrm{~kg}_{\mathrm{PE}} / \mathrm{mol}_{\mathrm{T}} / \mathrm{h} / \mathrm{bar}$.
\end{abstract} Ethylene/1-hexene and ethylene/styrene copolymerisations have shown these complexes to be good incorporators of comonomers into the polymer chain.

\section{Introduction}

In 1989, Stevens and coworkers at the Dow Chemical Company filed a patent containing the synthesis of a range of constrained geometry catalysts as olefin polymerisation and copolymerisation catalysts. ${ }^{1}$ A range of complexes were reported within this patent, with variation of the apical cyclopentadienyl $(\mathrm{Cp})$ type ligand (tetramethylcyclopentadienyl $\left(\mathrm{Cp}^{*}\right)$, indenyl (Ind, I)), amido group, heteroatom (various amido groups and phenylphosphido), ansa bridge (dimethylsilyl, tetramethyldisilyl, ethanediyl), and metal centre ( $\mathrm{Ti}, \mathrm{Zr}$ and $\mathrm{Hf}$ ). Early literature examples of CGCs include $\left[\left\{\left(\eta^{5}-\mathrm{C}_{5} \mathrm{Me}_{4}\right) \mathrm{Me}_{2} \operatorname{Si}\left({ }^{t B u} \mathrm{~N}\right)\right\} \operatorname{Sc}\left(\mathrm{PMe}_{3}\right)\right]_{2}(\mu-\mathrm{H})_{2}$ 
$\left(\left\{{ }^{\mathrm{Me}_{2}} \mathrm{SB}\left({ }^{t \mathrm{Bu}} \mathrm{N}, \mathrm{Cp}{ }^{*}\right)\right\}=\left\{\left(\eta^{5}-\mathrm{C}_{5} \mathrm{Me}_{4}\right) \mathrm{Me}_{2} \mathrm{Si}\left({ }^{t \mathrm{Bu}} \mathrm{N}\right)\right\}^{2-}\right)$, synthesised by Bercaw and co-workers in $1990,{ }^{2}$ and Okuda reporting a titanium complex, ${ }^{\mathrm{Me}_{2}} \mathrm{SB}\left({ }^{t \mathrm{Bu}} \mathrm{N},{ }^{3-t \mathrm{Bu}} \mathrm{Cp}\right) \mathrm{TiCl}_{2}$, in the same year. ${ }^{3}$ These complexes have been of great interest both academically and industrially due to their ability to efficiently polymerise ethylene and incorporate high levels of $\alpha$-olefins into a polymer chain. ${ }^{1,4-6}$

As demonstrated by Stevens and co-workers, ${ }^{1}$ cyclopentadienyl $(\mathrm{Cp})$ derivatives can be utilised, with Okuda and co-workers preparing both indenyl and fluorenyl (Flu) CGCs. ${ }^{7,8}$ Klosin and co-workers also reported the modification of indenyl constrained geometry complexes with addition of aryl, alkoxy and amino subsitituents at the 2-and 3-positions, with these substituents being shown to effect polymerisation activities and polymer molecular

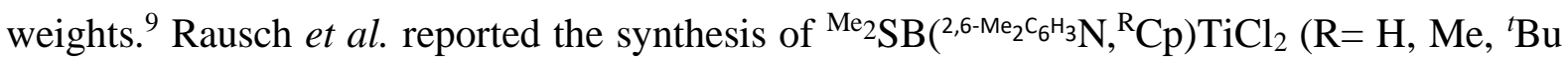
and $\mathrm{CH}_{2} \mathrm{Ph}$ ) with ethylene polymerisation activities following the trend $\mathrm{H}>\mathrm{Me}>\mathrm{CH} 2 \mathrm{Ph}>$ $\mathrm{tBu}^{10}$

Many early CGCs were synthesised with a dimethylsilyl ansa-bridge, with Reb and co-workers reporting a range of complexes with substitution of one methyl substituent for either a vinyl, phenyl, octenyl or hexenyl group. ${ }^{11,12}$ Since then, complexes have been reported with variation of the bridging atom, including boron, ${ }^{13,14}$ carbon, ${ }^{15,16}$ and phosphorus. ${ }^{17}$ Besides scandium and group 4 complexes, ${ }^{1-3,8,18}$ constrained geometry complexes have been reported for Y and La, ${ }^{19-}$ ${ }^{22}$ group $5,{ }^{23-25} 6,{ }^{26,27} 7$ and 8 metals, ${ }^{3,28}$ as well as group 13 and 15 complexes. $^{29-31}$

Numerous constrained geometry complexes have been synthesised with variation of X ligands, including amides, ${ }^{32,33}$ and the alkylated complexes ${ }^{{ }^{\mathrm{e}} 2}{ }_{2} \mathrm{SB}\left({ }^{t \mathrm{Bu}} \mathrm{N}, \mathrm{Cp} *\right) \mathrm{TiX}_{2}\left(\mathrm{X}=\mathrm{CH}_{2} \mathrm{Ph}\right.$ and $\left.\mathrm{Me}\right)$ reported by Chen and Marks. ${ }^{34}$ Outside of constrained geometry complexes, Lamb et al. have reported the synthesis of permethylindenyl (I*) metallocene complexes ${ }^{{ }^{\mathrm{e}}}{ }_{2} \mathrm{SB}\left({ }^{\mathrm{R}} \mathrm{Cp}, \mathrm{I}^{*}\right) \mathrm{ZrX} \mathrm{X}_{2}(\mathrm{R}$ $\left.=\mathrm{H}, \mathrm{Me},{ }^{n} \mathrm{Bu}, \mathrm{X}=\mathrm{Br}, \mathrm{Cl}, \mathrm{Me}, \mathrm{CH}_{2} \mathrm{Ph}\right) .{ }^{35}$ 
Since the pioneering work of Ziegler and Natta, ethylene polymerisation has been of great academical and industrial interest. ${ }^{36,37}$ While the majority of polyethylene-based polymers are still produced by Ziegler-Natta type catalysts, there has been a small shift towards production of polymers by metallocene-type molecular catalysts, both due to greater control of polymer microstructure, ${ }^{9}$ and the ability to incorporate higher levels of $\alpha$-olefins. ${ }^{38}$ A further advantage of these systems is the narrow molecular weight distributions of the copolymer produced and the chemical homogeneity through the polymers. ${ }^{38}$ A breakthrough in metallocene catalysed polymerisation was the discovery of methylaluminoxane (MAO) by Sinn and co-workers in 1980, which was found to significantly enhance polymerisation activities for these catalysts. ${ }^{39,40}$ There has been continued research into MAO as a cocatalyst; Ehm et al. have investigated the effect of variation of $\mathrm{Al}$ :Ti ratios on supporting $\mathrm{Cp}^{*}\left({ }^{t} \mathrm{Bu}_{3} \mathrm{P}=\mathrm{N}\right) \mathrm{TiCl}_{2}$ on $\mathrm{BHT}$ modified MAO (BHT = 2,6-di-tert-butyl-4-methylphenol) ${ }^{111}$ At high titanium loadings, homodinuclear adducts forming outer sphere ion pairs are dominant, whereas mononuclear inner sphere ion pairs are generally formed at lower loadings; both species were found to be viable precursors to the cationic active species. McIndoe et al. have investigated the effect of variation modifications to MAO, via alkyl exchange, ${ }^{112}$ or oxidation, ${ }^{113}$ and the effect in the structure of MAO studied.

Heterogeneous phase catalysts comprising of metallocene type complexes supported on an insoluble solid have been of great industrial interest, due to their ability to control polymer morphology and flowability, and helping to prevent reactor fouling. ${ }^{44}$ These supports include zirconium oxide, ${ }^{45}$ layered double hydroxides (LDHs),${ }^{46}$ clays $^{47}$ and zeolites $;{ }^{48}$ however, the most commonly used support is silica. ${ }^{44,49,50}$ Pre-treatment of silica with an alkylaluminium species, such as methylaluminoxane (MAO), is required. ${ }^{44}$ MAO has been shown to primarily chemisorb onto surface hydroxyl groups, leading to highly Lewis acidic sites. ${ }^{51}$ The site can then interact with metallocene-based pre-catalysts to form an ion pair ([CpR $\left.{ }_{2} \mathrm{M}-\mathrm{Me}\right][\mathrm{MAO}-$ 
$\mathrm{X}]$ ) active for polymerisation catalysis. ${ }^{52}$ Weckhuysen and co-workers have demonstrated that in silica supported MAO (SSMAO) the weak Lewis acid sites, responsible for $\mathrm{AlMe}_{2}{ }^{+}$, groups are responsible for the genesis of active metallocenes for olefin polymerisation. ${ }^{53,54}$ Boisson and co-workers have demonstrated the temperature of silica dihydroxylation in preparation of SSMAO affects polymerisation catalytic activity and polymer morphology, ${ }^{55}$ with the dihydroxylation temperature being shown to influence the levels of MAO impregnation possible on the silica surface. ${ }^{56}$

Solid polymethylaluminoxane (sMAO) is a polymerised methylaluminoxane which is insoluble in many common inorganic solvents. ${ }^{57,58} \mathrm{O}^{\prime}$ Hare and co-workers have previously demonstrated that sMAO supported catalysts exhibit significantly higher polymerisation activities than other supports, such as MAO-modified LDH and silica, and activities are similar to those reported for solution phase polymerisations. ${ }^{46,58,59}$

The hexamethylindenyl ligand $\left(\mathrm{C}_{9} \mathrm{Me}_{6}{ }^{-}\right.$, Ind $\left.{ }^{*}, \mathrm{I}^{*}\right)$ has been proposed to increase polymerisation activity for ethylene polymerisation and thermal stability relative to the indenyl ligand. This is attributed to inductive electronic donation and increased steric bulk around the metal centre. ${ }^{60-}$ ${ }^{62} \mathrm{O}$ 'Hare and co-workers have reported a number of $\mathrm{I}^{*}$ metallocene type complexes, both bispermethylindenyl complexes, ${ }^{61,63-65}$ and asymmetric ansa-bridged complexes, which have been shown to be highly active ethylene polymerisation catalysts. ${ }^{35,59,66} \mathrm{We}$ have also previously reported a family of permethylindenyl constrained geometry complexes,

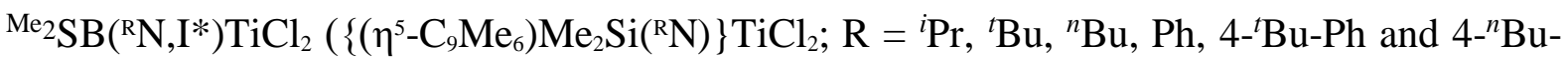
$\mathrm{Ph}$ ), with variation of the amido fragment. The complexes have been shown to be highly efficient ethylene polymerisation catalysts, with sMAO- ${ }^{\mathrm{Me}} 2 \mathrm{SB}\left({ }^{t \mathrm{Bu}} \mathrm{N}, \mathrm{I}^{*}\right) \mathrm{TiCl}_{2}$ having an activity three times that of sMAO- ${ }^{\mathrm{Me}_{2}} \mathrm{SB}\left({ }^{t \mathrm{Bu}} \mathrm{N}, \mathrm{Cp} *\right) \mathrm{TiCl}_{2} \cdot{ }^{67}$ 
Addition of an $\alpha$-olefin as comonomer to ethylene polymerisation reactions can allow for controlled addition of branches into polymer chains, significantly affecting the polymer properties and end usage. The greater degree of chain branching causes increased polymer flexibility, shifting usage towards foams, elastic fibres, packaging and adhesives. ${ }^{68}$ Waymouth and Dankova reported high levels of 1-hexene incorporation into ethylene/1-hexene copolymers using unbridged indenyl and aryl-indenyl metallocenes with a methylaluminoxane (MAO) cocatalyst; the hafnocene complexes demonstrated higher levels of 1-hexene incorporation than zirconocene analogues. ${ }^{69}$ Quijada and co-workers have also reported the use of ansa-bridged metallocenes, $\left(\mathrm{Me}_{2} \mathrm{SiCp}_{2}\right) \mathrm{ZrCl}_{2}$ and $\left(\mathrm{C}_{2} \mathrm{H}_{4} \mathrm{Ind}_{2}\right) \mathrm{ZrCl}_{2}\left((\mathrm{EBI}) \mathrm{ZrCl}_{2}\right)$, for ethylene/1-hexene copolymerisation with an MAO activator. ${ }^{70}$ It was found that the presence of the ansa-bridge resulted in greater levels of 1-hexene incorporation compared with the unbridged analogue, and lower polymer molecular weights due to the facilitation of $\beta$-hydride transfer reactions.

There have been a vast number of patents filed for the use of this family of complexes for ethylene/ $\alpha$-olefin copolymerisation. ${ }^{1,71}$ It was proposed that the strain inducing ansa-bridge opened the metal centre relative to the unbridged analogues, allowing for more facile coordination of comonomers such as 1-hexene or 1-octene. Klosin and co-workers have investigated the effects of the apical moiety for ethylene/1-octene copolymerisation. With use of a substituted indenyl fragment, the addition of electron-donating substituents led to both increased copolymerisation activity and polymer molecular weight, whilst still maintaining very high levels of comonomer incorporation. ${ }^{72}$ Marks and Chen investigated ${ }^{\mathrm{Me}_{2}} \mathrm{SB}\left({ }^{t \mathrm{Bu}} \mathrm{N}, \mathrm{Cp}{ }^{*}\right) \mathrm{TiX}_{2}\left(\mathrm{X}=\mathrm{CH}_{2} \mathrm{Ph}\right.$ and $\left.\mathrm{Me}\right)$ for homogeneous phase ethylene/1-hexene copolymerisation with MAO and borane cocatalysts; the dimethyl complex showed high levels of 1-hexene incorporation, whilst the dibenzyl complex resulted in the formation of a mixture of two homopolymers. ${ }^{34}$ Ethylene/1-hexene copolymerisation has also been studied in 
heterogeneous systems; Marks and Williams reported the use of CGCs supported by MAOactivated sulfated alumina for slurry phase ethylene/1-hexene copolymerisation. ${ }^{73}$ The supported species resulted in significantly lower levels of 1-hexene incorporation due to mass transfer effects, where both the support and the propagating polymer chain cause diffusional resistance of the comonomer. ${ }^{74}$

Heterogeneous Ziegler-Natta catalysts are not suitable for ethylene/styrene copolymerisations, not only are incorporation levels are below $1 \%$, but the polymers obtained are mixtures of homo- and copolymers due to the presence of several unique active sites. ${ }^{75,76}$ Nomura et al. have reported ethylene/styrene copolymerisation with (aryloxo)(cyclopentadienyl)titanium complexes producing poly(ethylene-co-styrene) exclusively with incorporations up to 49 mol\%. ${ }^{77,78}$ These complexes were shown to be unable to homopolymerise styrene, and as such no block polystyrene impurities are formed. ${ }^{1}$ Bulky substituents on the cyclopentadienyl ring have been shown to reduce styrene incorporation due to steric hindrance;

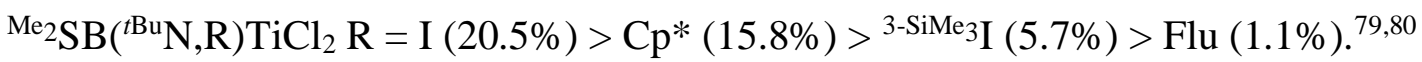

Herein, we report the synthesis and characterisation of nine new constrained geometry complexes, derivatives of ${ }^{\mathrm{Me}_{2}} \mathrm{SB}\left({ }^{t \mathrm{Bu}} \mathrm{N}, \mathrm{I}^{*}\right) \mathrm{TiCl}_{2}$, their use in slurry phase ethylene homopolymerisation, and ethylene/1-hexene and ethylene/styrene copolymerisations.

\section{Results and discussion}

\subsection{Synthesis and characterisation of complexes}

\subsubsection{Synthesis and characterisation of a ${ }^{\mathrm{Me}_{2}} \mathrm{SB}\left({ }^{t \mathrm{Bu}} \mathrm{N}, \mathrm{I}^{*}\right) \mathrm{Ti}(\mathrm{Cl}) \mathrm{CH}_{2} \mathrm{SiMe}_{3}$ and}

$$
{ }^{{ }^{M e}}{ }_{2} \mathrm{SB}\left({ }^{(\mathrm{Bu}} \mathrm{N}, \mathrm{I}^{*}\right) \mathrm{TiR}_{2}\left(\mathrm{R}=\mathrm{Me}, \mathrm{CH}_{2} \mathrm{Ph} \text { and } \mathrm{CH}_{2} \mathrm{SiMe}_{3}\right)
$$

${ }^{\mathrm{Me}_{2}} \mathrm{SB}\left({ }^{t \mathrm{Bu}} \mathrm{N}, \mathrm{I}^{*}\right) \mathrm{TiCl}_{2}$ was synthesised following a previously reported method. ${ }^{67}$ Its reaction

with the appropriate alkali metal salt afforded $\left.{ }^{{ }^{M e}}{ }_{2} \mathrm{SB}{ }^{t B u} \mathrm{~N}, \mathrm{I} *\right) \mathrm{Ti}(\mathrm{Cl}) \mathrm{CH}_{2} \mathrm{SiMe}_{3}$, 
2.1).

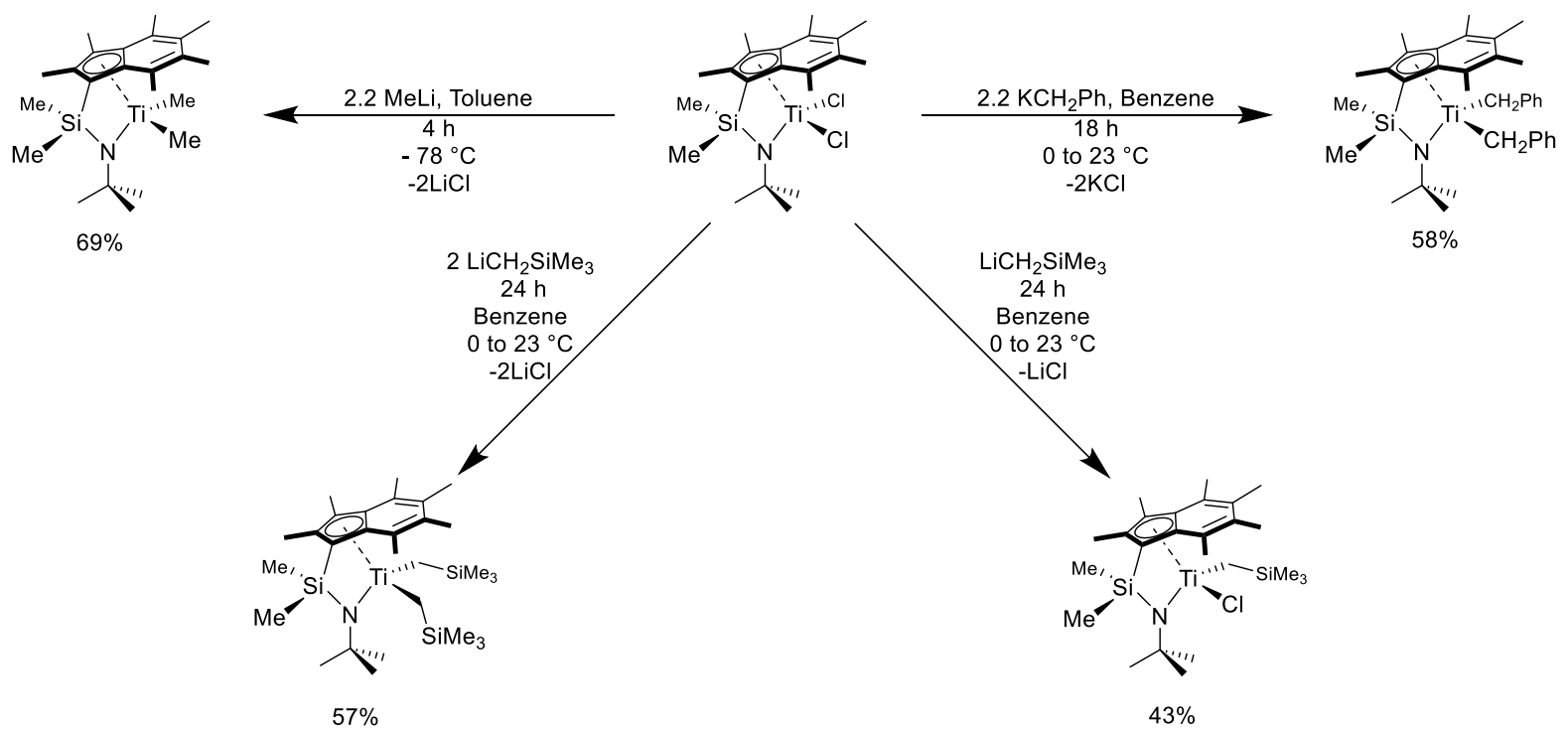

Scheme 2.1. Synthetic procedure for the synthesis of ${ }^{\mathrm{Me}_{2}} \mathrm{SB}\left({ }^{\mathrm{B} u} \mathrm{~N}, \mathrm{I} *\right) \mathrm{Ti}(\mathrm{Cl}) \mathrm{CH}_{2} \mathrm{SiMe}_{3}$ and ${ }^{\mathrm{Me}_{2}} \mathrm{SB}\left({ }^{t \mathrm{Bu}} \mathrm{N}, \mathrm{I}^{*}\right) \mathrm{TiR}_{2}\left(\mathrm{R}=\mathrm{Me}, \mathrm{CH}_{2} \mathrm{Ph}\right.$ and $\left.\mathrm{CH}_{2} \mathrm{SiMe}_{3}\right)$ from ${ }^{{ }^{\mathrm{Me}}}{ }_{2} \mathrm{SB}\left({ }^{t \mathrm{Bu}} \mathrm{N}, \mathrm{I}^{*}\right) \mathrm{TiCl}_{2}$.

Reaction of ${ }^{{ }^{\mathrm{Me}}}{ }_{2} \mathrm{SB}\left({ }^{t \mathrm{Bu}} \mathrm{N}, \mathrm{I}^{*}\right) \mathrm{TiCl}_{2}$ with 2.2 equivalents of either MeLi in toluene or $\mathrm{KCH}_{2} \mathrm{Ph}$ in

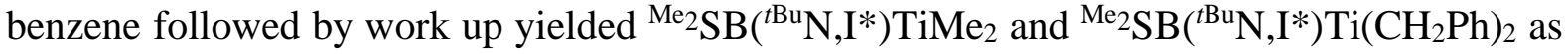
brown or dark-red solids in 69 and $58 \%$ yield respectively (Scheme 2.1).

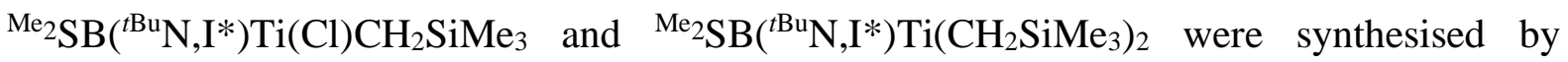
reaction of ${ }^{\mathrm{Me}_{2}} \mathrm{SB}\left({ }^{t \mathrm{Bu}} \mathrm{N}, \mathrm{I}^{*}\right) \mathrm{TiCl}_{2}$ with 1 or 2 equivalents of $\mathrm{Li}\left(\mathrm{CH}_{2} \mathrm{SiMe}_{3}\right)_{2}$ in benzene to afford both complexes after work up as orange crystalline solids in 57 and $43 \%$ yield respectively (Scheme 2.1).

The ${ }^{1} \mathrm{H}$ NMR spectrum of ${ }^{{ }^{2}}{ }_{2} \mathrm{SB}\left({ }^{t B u} \mathrm{~N}, I^{*}\right) \mathrm{TiMe}_{2}$ (Figure S2.1) shows two singlets at 0.58 and $-0.14 \mathrm{ppm}$ that correspond to two methyl groups bound to the titanium centre. Six singlets can be observed in the $2.00-2.50 \mathrm{ppm}$ region which represent the I* methyl protons, a singlet at $1.51 \mathrm{ppm}$ is assigned to the ${ }^{t} \mathrm{Bu}-\mathrm{N}$ group, and the silyl-methyl groups are represented by resonances at 0.64 and $0.63 \mathrm{ppm}$. 
The ${ }^{1} \mathrm{H}$ NMR spectra of ${ }^{\mathrm{Me}_{2}} \mathrm{SBB}\left({ }^{t \mathrm{Bu}} \mathrm{N}, \mathrm{I}{ }^{*}\right) \mathrm{Ti}\left(\mathrm{CH}_{2} \mathrm{Ph}\right)_{2},{ }^{\mathrm{Me}_{2}}{ }_{2} \mathrm{SB}\left({ }^{t \mathrm{Bu}} \mathrm{N}, \mathrm{I}{ }^{*}\right) \mathrm{Ti}\left(\mathrm{CH}_{2} \mathrm{SiMe}_{3}\right)_{2}$ and

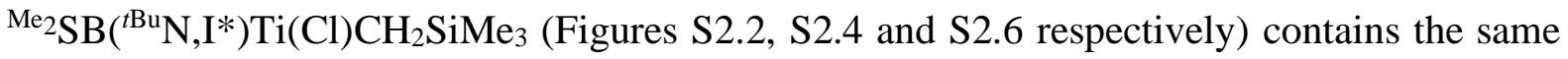
diagnostic resonances for the constrained geometry ligand as for ${ }^{\mathrm{Me}_{2}} \mathrm{SB}\left({ }^{t \mathrm{Bu}} \mathrm{N}, \mathrm{I}^{*}\right) \mathrm{TiMe}_{2}$. However, in the neosilyl complex, doublets are also observed at 1.22, 0.98, 0.65 and $-0.87 \mathrm{ppm}$, which correspond to the four protons of the diastereotopic methylene groups bound to the titanium. The ${ }^{1} \mathrm{H}-{ }^{1} \mathrm{HROESY}$ NMR spectrum shows that the neosilyl group directed under the $I^{*}$ ring (observed to correlate to the $I^{*}$ methyl protons of the six membered fused ring) corresponded to the more negatively shifted $\mathrm{SiMe}_{3}$ group (0.02 ppm). The methylene units also show the same correlation between chemical shift and position relative to the $I^{*}$ ring. This is due to the diamagnetic anisotropy associated with the aromatic I* ring leading to a shift for the $\mathrm{SiMe}_{3}$ group outside the ring to higher frequency and to lower frequency for the group placed under the ring. ${ }^{81}$ In the dibenzyl complex, triplets at 7.16, 7.06, 6.92 and $6.83 \mathrm{ppm}$ and doublets at 6.94 and $6.71 \mathrm{ppm}$ have been assigned to the phenyl groups according to the ${ }^{1} \mathrm{H}-{ }^{1} \mathrm{H}$ COSY NMR spectrum. Doublets observed at 2.70, 2.40, 1.59 and $1.52 \mathrm{ppm}$ correspond to the four protons of the diastereotopic methylene units bound to titanium showing different orientations of the benzyl groups relative to the $\mathrm{I}^{*}$ ring as is seen in ${ }^{\mathrm{Me}}{ }_{2} \mathrm{SB}\left({ }^{t \mathrm{Bu}} \mathrm{N}, \mathrm{I}^{*}\right) \mathrm{Ti}\left(\mathrm{CH}_{2} \mathrm{SiMe}_{3}\right)_{2}$. The assignment of the doublets are confirmed by ${ }^{1} \mathrm{H}-{ }^{1} \mathrm{H}$ COSY and ROESY NMR spectroscopy. In the ${ }^{1} \mathrm{H}$ NMR spectrum of ${ }^{\mathrm{Me}_{2}} \mathrm{SB}\left({ }^{t \mathrm{Bu}} \mathrm{N}, \mathrm{I}^{*}\right) \mathrm{Ti}(\mathrm{Cl}) \mathrm{CH}_{2} \mathrm{SiMe}_{3}$ (Figure S2.6), a singlet at $0.63 \mathrm{ppm}$ corresponds to the $\mathrm{SiMe}_{3}$ group, whilst the methylene protons are observed as a pair of roofed doublets at 1.57 and -0.97 ppm, with a ${ }^{2} J_{\mathrm{H}-\mathrm{H}}$ coupling of $11.9 \mathrm{~Hz}$.

Crystals suitable for analysis by single crystal X-ray diffraction studies were grown from pentane at $-20{ }^{\circ} \mathrm{C}$ for the complexes ${ }^{\mathrm{Me}_{2}} \mathrm{SB}\left({ }^{t \mathrm{Bu}} \mathrm{N}, \mathrm{I}^{*}\right) \mathrm{TiMe}_{2},{ }^{\mathrm{Me}}{ }_{2} \mathrm{SB}\left({ }^{t \mathrm{Bu}} \mathrm{N}, \mathrm{I} *\right) \mathrm{Ti}\left(\mathrm{CH}_{2} \mathrm{SiMe}_{3}\right)_{2}$ and

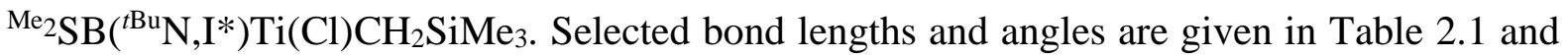
the molecular structures are shown in Figure 2.1. 
Table 2.1. Selected bond lengths ( $⿱$ ) and angles $\left(^{\circ}\right)$ for ${ }^{{ }^{\mathrm{M}}}{ }_{2} \mathrm{SB}\left({ }^{t \mathrm{Bu}} \mathrm{N}, \mathrm{I}^{*}\right) \mathrm{TiMe}_{2}$, ${ }^{\mathrm{Me}_{2}} \mathrm{SB}\left({ }^{t \mathrm{Bu}} \mathrm{N}, \mathrm{I}^{*}\right) \mathrm{Ti}\left(\mathrm{CH}_{2} \mathrm{SiMe}_{3}\right)_{2}$, and ${ }^{\mathrm{Me}} 2 \mathrm{SB}\left({ }^{\mathrm{BBu}} \mathrm{N}, \mathrm{I}^{*}\right) \mathrm{Ti}(\mathrm{Cl}) \mathrm{CH}_{2} \mathrm{SiMe}_{3}$. Estimated standard deviations (ESDs) are given in parentheses.

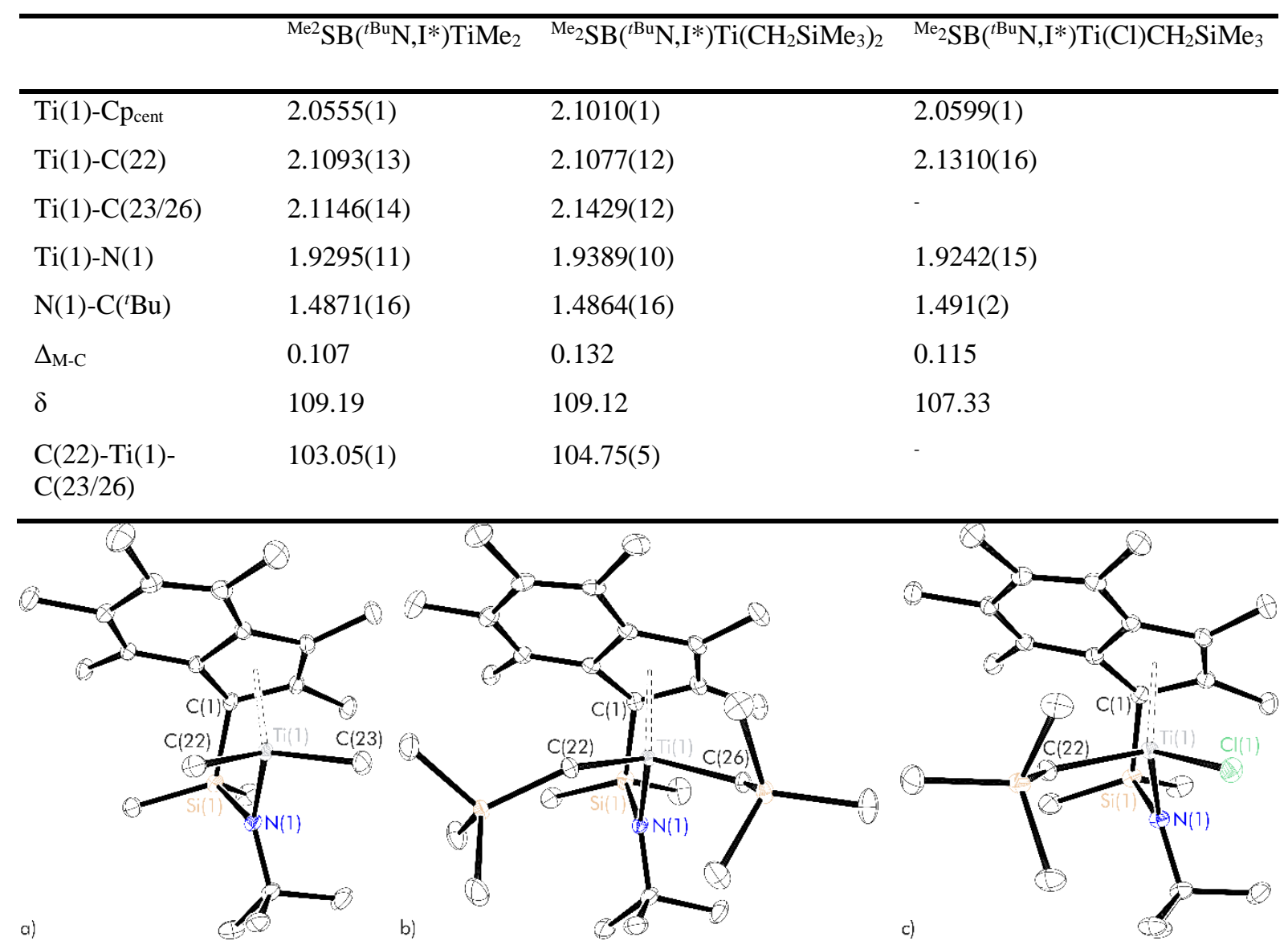

Figure 2.1. Solid-state molecular structures of (a) ${ }^{\mathrm{Me}_{2}}{ }_{2} \mathrm{SB}\left({ }^{\mathrm{ABu}} \mathrm{N}, \mathrm{I}^{*}\right) \mathrm{TiMe}_{2}$, (b) ${ }^{\mathrm{Me}_{2}}{ }_{2} \mathrm{SB}\left({ }^{t \mathrm{Bu}} \mathrm{N}, \mathrm{I}^{*}\right) \mathrm{Ti}\left(\mathrm{CH}_{2} \mathrm{SiMe}_{3}\right)_{2}$, and (c) ${ }^{\mathrm{Me}_{2}} \mathrm{SB}\left({ }^{t \mathrm{Bu}} \mathrm{N}, \mathrm{I}{ }^{*}\right) \mathrm{Ti}(\mathrm{Cl}) \mathrm{CH}_{2} \mathrm{SiMe}_{3}$. Hydrogen atoms have been omitted for clarity. Thermal ellipsoids are drawn at $30 \%$ probability.

The shorter Ti-Cp cent distance in ${ }^{\mathrm{Me}_{2}} \mathrm{SB}\left({ }^{t \mathrm{Bu}} \mathrm{N}, \mathrm{I} *\right) \mathrm{TiMe}_{2}$ compared to ${ }^{\mathrm{Me}_{2}} \mathrm{SB}\left({ }^{t \mathrm{Bu}} \mathrm{N}, \mathrm{I}\right) \mathrm{TiMe}_{2}$ (2.0555(1) and $2.091 \AA$ respectively) can be attributed to the stronger bonding between the more electron rich $I^{*}$ moiety and titanium. ${ }^{82}$ The similar Ti-Cp $p_{c e n t}$ distance in

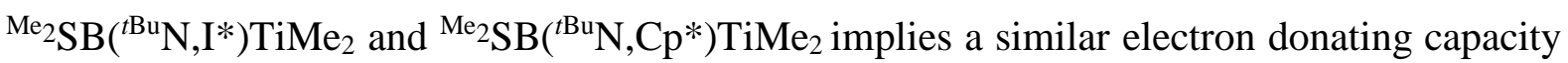
of the I* and $\mathrm{Cp}^{*}$ moieties. ${ }^{82}$ The comparable $\Delta_{\mathrm{M}-\mathrm{C}}$ distance of ${ }^{{ }^{\mathrm{Me}} 2}{ } \mathrm{SB}\left({ }^{t \mathrm{Bu}} \mathrm{N}, \mathrm{I}^{*}\right) \mathrm{TiMe}_{2}(0.107 \AA)$ and $\left.{ }^{\mathrm{Me}_{2}} \mathrm{SB}^{\mathrm{tBu}} \mathrm{N}, \mathrm{I}\right) \mathrm{TiMe}_{2}(0.106 \AA)$ shows a propensity to undergo the $\eta^{5}-\eta^{3}$ ring slip characteristic of indenyl metallocenes when compared to the small $\Delta_{\mathrm{M}-\mathrm{C}}$ distance in 
${ }^{\mathrm{Me}_{2}} \mathrm{SB}\left({ }^{t \mathrm{Bu}} \mathrm{N}, \mathrm{Cp}{ }^{*}\right) \mathrm{TiMe}_{2}(0.04 \AA)$. The $\delta$ angle increases as the Cp type ligand is changed from Cp* to Ind to I*. The difference between ${ }^{\mathrm{Me}_{2}} \mathrm{SB}\left({ }^{\mathrm{B} u} \mathrm{~N}, \mathrm{I}^{*}\right) \mathrm{TiMe}_{2}$ and ${ }^{\mathrm{Me}_{2}} \mathrm{SB}\left({ }^{t \mathrm{Bu}} \mathrm{N}, \mathrm{Cp} *\right) \mathrm{TiMe}_{2}$ could be an effect of the $\eta^{5}-\eta^{3}$ ring slip, the reduction of strain in moving away from the more sterically demanding $\eta^{5}$ coordination mode. The larger $\Delta_{\mathrm{M}-\mathrm{C}}$ distance of ${ }^{\mathrm{Me}}{ }_{2} \mathrm{SB}\left({ }^{t \mathrm{Bu}} \mathrm{N}, \mathrm{I}^{*}\right) \mathrm{Ti}\left(\mathrm{CH}_{2} \mathrm{SiMe}_{3}\right)_{2}$ the infers a greater propensity to $\eta^{5}-\eta^{3}$ ring slip. Though this may seem counter-intuitive given the larger steric bulk of the $\mathrm{CH}_{2} \mathrm{SiMe}_{3}$ groups of

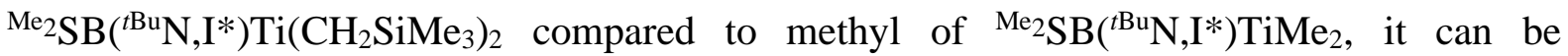
rationalised by the longer Ti-C $\mathrm{p}_{\text {cent }}$ distance allowing for the $\mathrm{I}^{*}$ moiety to adopt a position with less steric interaction. The rotation of the $\mathrm{CH}_{2} \mathrm{SiMe}_{3}$ group about the methylene unit allows the bulky $\mathrm{SiMe}_{3}$ groups to be orientated away from the I* ring; hence, reducing their steric influence on the ring.

The longer Ti-Cpent and Ti-N distance in ${ }^{\mathrm{Me}_{2}} \mathrm{SB}\left({ }^{t \mathrm{Bu}} \mathrm{N}, \mathrm{I}^{*}\right) \mathrm{Ti}\left(\mathrm{CH}_{2} \mathrm{SiMe}_{3}\right)_{2}$ (2.1010(1) and $1.9389(10) \AA)$ compared to ${ }^{\mathrm{Me}_{2}} \mathrm{SB}\left({ }^{t \mathrm{Bu}} \mathrm{N}, \mathrm{I}^{*}\right) \mathrm{TiMe}_{2}(2.0555(1)$ and $1.9295(11) \AA)$ implies weaker bonding to the constrained geometry ligand but may simply be a consequence of the larger neosilyl ligands. ${ }^{\mathrm{Me}}{ }_{2} \mathrm{SB}\left({ }^{t \mathrm{Bu}} \mathrm{N}, \mathrm{I}^{*}\right) \mathrm{Ti}(\mathrm{Cl}) \mathrm{CH}_{2} \mathrm{SiMe}_{3}$ has Ti-Cpent and Ti-N distances similar to that of ${ }^{\mathrm{Me}_{2}} \mathrm{SB}\left({ }^{t \mathrm{Bu}} \mathrm{N}, \mathrm{I}^{*}\right) \mathrm{TiMe}_{2}(2.0599(1)$ and $1.9242(15) \AA)$, although all of these are greater than ${ }^{\mathrm{Me}_{2}} \mathrm{SB}\left({ }^{-\mathrm{Bu}} \mathrm{N}, \mathrm{I}^{*}\right) \mathrm{TiCl}_{2}(2.0386(1)$ and $1.910(2) \AA)$, indicating the greater electron donating ability of the alkyl initiator groups relative to chloride. The increased electron density at the titanium centre reduces the extent of donation from the I* ligand hence weakening its bonding interaction.

\subsubsection{Synthesis and characterisation of ${ }^{\mathrm{Me}_{2}} \mathrm{SB}\left({ }^{\mathrm{Cy}} \mathrm{N}, \mathrm{I}^{*}\right) \mathrm{TiCl}_{2}$}

${ }^{\mathrm{Me}_{2}} \mathrm{SB}\left({ }^{\mathrm{Cy}} \mathrm{N}, \mathrm{I}^{*}\right) \mathrm{H}_{2}$ was synthesised by reaction of $\mathrm{I}^{*} \mathrm{SiMe}_{2} \mathrm{Cl}$ with an equimolar amount of $\mathrm{LiN}(\mathrm{H}) \mathrm{Cy}$. Subsequent reaction with 2.2 equivalents with ${ }^{n} \mathrm{BuLi}$ yielded the dilithium salt

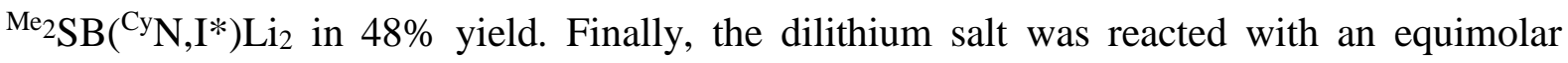


amount of $\mathrm{TiCl}_{4}$. $2 \mathrm{THF}$ to yield ${ }^{\mathrm{Me}_{2}} \mathrm{SB}\left({ }^{\mathrm{Cy}} \mathrm{N}, \mathrm{I}^{*}\right) \mathrm{TiCl}_{2}$ as a dark red solid in $14 \%$ isolated yield following work up (Equation 2.1).

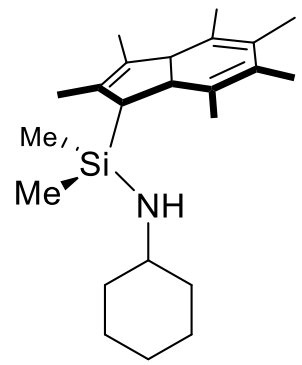

i) 2.2 eq ${ }^{n} \mathrm{BuLi}, \mathrm{THF}, 0^{\circ} \mathrm{C}$ to $\mathrm{RT}, 1 \mathrm{~h}$

ii) $\mathrm{TiCl}_{4} .2 \mathrm{THF}$, benzene, $23^{\circ} \mathrm{C}, 18 \mathrm{~h}$

$-2 \mathrm{BuH},-2 \mathrm{LiCl},-2 \mathrm{THF}$

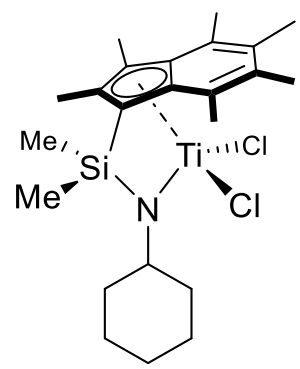

Equation 2.1. Synthetic route to ${ }^{\mathrm{Me}_{2}} \mathrm{SB}\left({ }^{\mathrm{Cy}} \mathrm{N}, \mathrm{I}^{*}\right) \mathrm{TiCl}_{2}$.

In the ${ }^{1} \mathrm{H}$ NMR spectrum (Figure S2.11), as well as the characteristic resonances for the I*-Me, and Si-Me groups observed in all ${ }^{\mathrm{Me}}{ }_{2} \mathrm{SB}\left({ }^{\mathrm{R}} \mathrm{N}, \mathrm{I}^{*}\right) \mathrm{TiX}_{2}$ complexes, the $\mathrm{CH}$ proton of the cyclohexyl amido group can be assigned to the multiplet at $4.75 \mathrm{ppm}$. By use of COSY, HSQC and HMBC NMR spectrocopy, it is possible to fully assign resonances in the range of 0.87 to $2.13 \mathrm{ppm}$ to the remaining protons of the cyclohexyl group.

\subsubsection{Synthesis and characterisation of ${ }^{\mathrm{Me}}{ }_{2} \mathrm{SB}\left({ }^{t{ }^{B u}}{ }_{N},{ }^{3-E_{1}}{ }^{*}\right) \mathrm{TiCl}_{2}$}

${ }^{3-E t}{ }^{*} * \mathrm{SiMe}_{2} \mathrm{Cl}$ was prepared by reaction of three equivalents of $\mathrm{SiMe}_{2} \mathrm{Cl}_{2}$ with ${ }^{3-\mathrm{Et}} \mathrm{Ind}^{\#} \mathrm{Li}^{64}$ in an $83 \%$ yield; the ${ }^{1} \mathrm{H}$ NMR spectrum is shown in Figure $\mathrm{S} 2.13 .{ }^{3-\mathrm{Et}} \mathrm{I}^{*} \mathrm{SiMe}_{2} \mathrm{Cl}$ was then reacted with an equimolar amount of $\mathrm{LiN}(\mathrm{H}){ }^{t} \mathrm{Bu}$ and, following work up, ${ }^{\mathrm{Me}}{ }_{2} \mathrm{SB}\left({ }^{t \mathrm{Bu}} \mathrm{N},{ }^{3-\mathrm{E} t} \mathrm{I}^{*}\right) \mathrm{H}_{2}$ was isolated as a yellow oil in a quantitative yield; the ${ }^{1} \mathrm{H}$ NMR spectrum is shown in Figure S2.14. Reaction of the proligand with 2.2 equivalents of ${ }^{n} \mathrm{BuLi}$ yielded ${ }^{{ }^{\mathrm{Me}}}{ }_{2} \mathrm{SB}\left({ }^{\mathrm{tBu}} \mathrm{N},{ }^{3-\mathrm{Et}}{ }^{*}\right) \mathrm{Li}_{2}$ in a $58 \%$ yield following work up; the ${ }^{1} \mathrm{H}$ NMR spectrum is shown in Figure $\mathrm{S} 2.16 .{ }^{\mathrm{Me}} 2 \mathrm{SB}\left({ }^{t \mathrm{Bu}} \mathrm{N},{ }^{3-\mathrm{Et}} \mathrm{I}^{*}\right) \mathrm{Li}_{2}$ was reacted with an equimolar amount of $\mathrm{TiCl}_{4} .2 \mathrm{THF}$ to yield ${ }^{\mathrm{Me}_{2}}{ }_{2} \mathrm{SB}\left({ }^{\mathrm{tBu}} \mathrm{N},{ }^{3-\mathrm{Et}}{ }^{*}\right) \mathrm{TiCl}_{2}$ in an $18 \%$ yield as a red solid (Equation 2.2). 


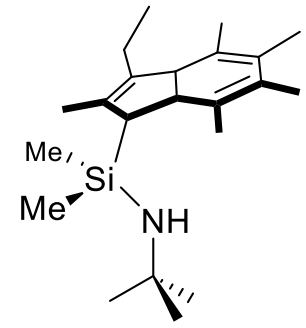

i) 2.2 eq ${ }^{n} \mathrm{BuLi}, \mathrm{THF}, 0{ }^{\circ} \mathrm{C}$ to $\mathrm{RT}, 1 \mathrm{~h}$

ii) $\mathrm{TiCl}_{4} .2 \mathrm{THF}$, benzene, $23^{\circ} \mathrm{C}, 18 \mathrm{~h}$

$-2 \mathrm{BuH},-2 \mathrm{LiCl},-2 \mathrm{THF}$

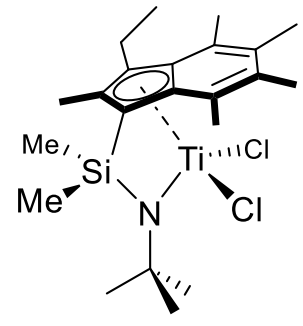

Equation 2.2. Synthetic route to ${ }^{\mathrm{Me}_{2}} \mathrm{SB}\left({ }^{t B u} \mathrm{~N},{ }^{3-\mathrm{Et}} \mathrm{I} *\right) \mathrm{TiCl}_{2}$.

The ${ }^{1} \mathrm{H}$ NMR spectrum of ${ }^{{ }^{\mathrm{Me}} 2} \mathrm{SB}\left({ }^{t \mathrm{Bu}} \mathrm{N},{ }^{3-\mathrm{Et}} \mathrm{I}^{*}\right) \mathrm{TiCl}_{2}$ confirms the presence of only five $\mathrm{I}^{*}-\mathrm{Me}$ resonances in the range of 2.03 to $2.45 \mathrm{ppm}$ (Figure S2.17). Three resonances are observed for the ethyl chain; a pair of multiplets at 3.34 and $3.03 \mathrm{ppm}$ corresponding to the methylene protons, with the presence of both ${ }^{2} J_{\mathrm{H}-\mathrm{H}}$ and ${ }^{3} J_{\mathrm{H}-\mathrm{H}}$ coupling, and a doublet of doublets corresponding to the methyl group, which appears to be a triplet as both sets of ${ }^{3} J_{H-\mathrm{H}}$ coupling is $7.6 \mathrm{~Hz}$.

\subsubsection{Synthesis and characterisation of ${ }^{\mathrm{Me}, \operatorname{Pr}} \mathrm{SB}\left({ }^{t \mathrm{Bu}} \mathrm{N}, \mathrm{I}^{*}\right) \mathrm{TiCl}_{2}$}

$\mathrm{Ind}^{\#} \mathrm{Li}$ was added dropwise to 1.5 equivalents of $\mathrm{Si}(\mathrm{Me}, \mathrm{Pr}) \mathrm{Cl}_{2}$ to yield $\mathrm{I}^{*} \mathrm{SiR}_{1} \mathrm{R}_{2} \mathrm{Cl}$ as a pale orange solid as a mixture of two isomers. $\mathrm{I}^{*}(\mathrm{Me}, \mathrm{Pr}) \mathrm{Cl}$ was then reacted with 1.05 equivalents of $\mathrm{LiN}(\mathrm{H}){ }^{t} \mathrm{Bu}$ and, following work up, the products ${ }^{\mathrm{Me}, \operatorname{Pr}} \mathrm{SB}\left({ }^{t \mathrm{Bu}} \mathrm{N}, \mathrm{I}^{*}\right) \mathrm{H}_{2}$ were isolated. Addition of 2.2 equivalents of ${ }^{n} \mathrm{BuLi}$ to ${ }^{\mathrm{Me}, \operatorname{Pr}} \mathrm{SB}\left({ }^{t \mathrm{Bu}} \mathrm{N}, \mathrm{I}^{*}\right) \mathrm{H}_{2}$ resulted in the formation of

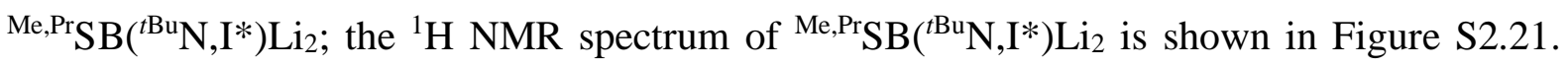

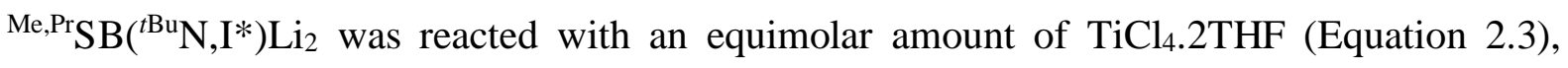
following work up ${ }^{\mathrm{Me}, \mathrm{Pr}} \mathrm{SB}\left({ }^{t \mathrm{Bu}} \mathrm{N}, \mathrm{I}^{*}\right) \mathrm{TiCl}_{2}$ was afforded as red oily solid in $20 \%$ yield respectively.

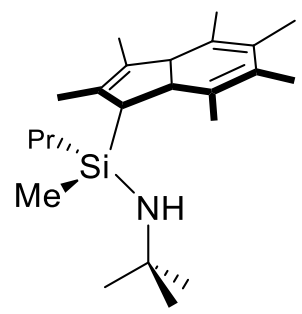

i) $2.2 \mathrm{eq}{ }^{n} \mathrm{BuLi}, \mathrm{THF}, 0{ }^{\circ} \mathrm{C}$ to $\mathrm{RT}, 1 \mathrm{~h}$

ii) $\mathrm{TiCl}_{4} .2 \mathrm{THF}$, benzene, $23^{\circ} \mathrm{C}, 18 \mathrm{~h}$

$-2 \mathrm{BuH},-2 \mathrm{LiCl},-2 \mathrm{THF}$

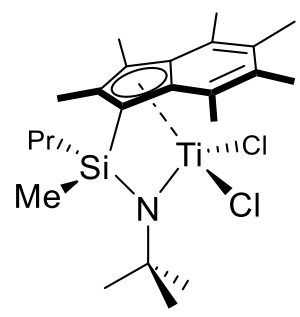

Equation 2.3. Synthetic route to ${ }^{\mathrm{Me}, \mathrm{Pr}} \mathrm{SB}\left({ }^{t \mathrm{Bu}} \mathrm{N}, \mathrm{I}^{*}\right) \mathrm{TiCl}_{2}$ 
In ${ }^{\mathrm{Me}, \mathrm{Pr}} \mathrm{SB}\left({ }^{\mathrm{tBu}} \mathrm{N}, \mathrm{I}^{*}\right) \mathrm{TiCl}_{2}$, the conformationally locked nature of the product leads to a pair of two diastereoisomers in a 57:43 ratio as determined from the ${ }^{1} \mathrm{H}$ NMR spectrum (Figure S2.22). The I*-Me resonances of the major isomer are observed between 2.36 and $2.56 \mathrm{ppm}$, whilst the resonances for the minor isomer are found between 2.02 and $2.19 \mathrm{ppm}$. Both $\mathrm{N}-{ }^{t} \mathrm{Bu}$ resonances are observed at $1.42 \mathrm{ppm}$, the Si-Me resonances at 0.63 and $0.58 \mathrm{ppm}$, and the $\mathrm{Si}-\mathrm{Pr}$ resonances between 1.74 and $1.04 \mathrm{ppm}$.

\subsubsection{Synthesis and characterisation of ${ }^{\mathrm{Me}}{ }_{2} \mathrm{SB}\left({ }^{t \mathrm{Bu}} \mathrm{N}, \mathrm{I}^{*}\right) \mathrm{ZrCl}_{2}$}

${ }^{\mathrm{Me}_{2}} \mathrm{SB}\left({ }^{t \mathrm{Bu}} \mathrm{N}, \mathrm{I}^{*}\right) \mathrm{Li}_{2}$ was reacted with an equimolar amount of $\mathrm{ZrCl}_{4}$ to yield ${ }^{\mathrm{Me}} 2 \mathrm{SB}\left({ }^{t \mathrm{Bu}} \mathrm{N}, \mathrm{I}^{*}\right) \mathrm{ZrCl}_{2}$ in a $24 \%$ yield as a dark orange/brown solid following work up (Equation 2.4). The ${ }^{1} \mathrm{H}$ NMR spectrum contains the same diagnostic ligand resonances as found in the titantium analogues ${ }^{\mathrm{Me} 2} \mathrm{SB}\left({ }^{t \mathrm{Bu}} \mathrm{N}, \mathrm{I} *\right) \mathrm{TiX}_{2}$ (Figure $\left.\mathrm{S} 2.24\right)$.

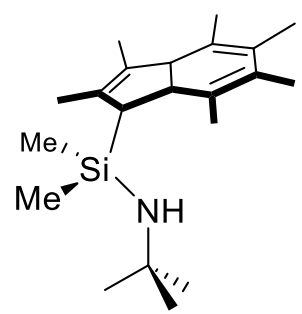

i) 2.2 eq ${ }^{n} \mathrm{BuLi}, \mathrm{THF}, 0^{\circ} \mathrm{C}$ to $\mathrm{RT}, 1 \mathrm{~h}$

ii) $\mathrm{ZrCl}_{4}$, benzene, $23^{\circ} \mathrm{C}, 18 \mathrm{~h}$

$-2 \mathrm{BuH},-2 \mathrm{LiCl},-2 \mathrm{THF}$

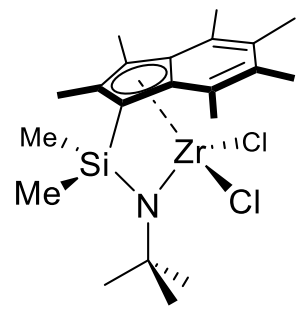

Equation 2.4. Synthetic route to ${ }^{\mathrm{Me}_{2}} \mathrm{SB}\left({ }^{t \mathrm{Bu}} \mathrm{N}, \mathrm{I}^{*}\right) \mathrm{ZrCl}_{2}$

\subsection{Immobilisation of complexes}

The complexes were supported on solid polymethylaluminoxane (sMAO), ${ }^{57,58}$ a modified, polymerised methylaluminoxane that is insoluble in many common organic solvents. The complex was mixed with sMAO with an Al:Ti ratio of 200:1 (Equation 2.5). 

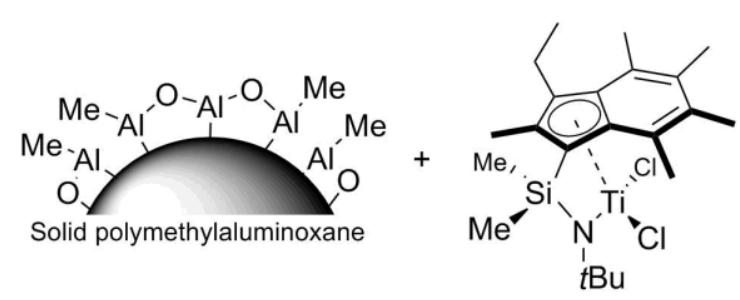

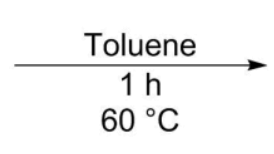

$60^{\circ} \mathrm{C}$

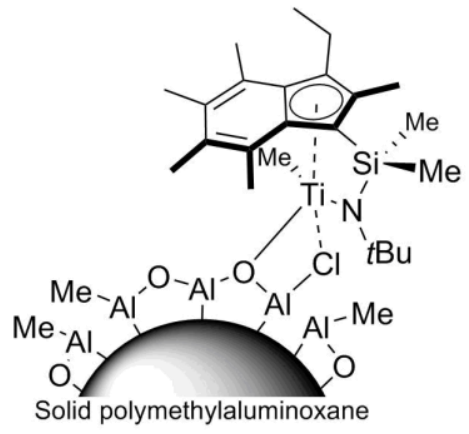

Equation 2.5. Schematic representation of the immobilisation of ${ }^{\mathrm{Me}_{2}} \mathrm{SB}\left({ }^{\mathrm{tBu}} \mathrm{N},{ }^{3-\mathrm{Et}} \mathrm{I} *\right) \mathrm{TiCl}_{2}$ on SMAO.

The ${ }^{13} \mathrm{CP}-\mathrm{MAS}$ NMR spectra of sMAO- ${ }^{\mathrm{Me}}{ }_{2} \mathrm{SB}\left({ }^{t \mathrm{Bu}} \mathrm{N}, \mathrm{I}^{*}\right) \mathrm{TiR}_{2}\left(\mathrm{R}=\mathrm{CH}_{2} \mathrm{Ph}, \mathrm{Me}\right.$ and $\left.\mathrm{CH}_{2} \mathrm{SiMe}_{3}\right)$ and sMAO- $\left.{ }^{\mathrm{Me}_{2}} \mathrm{SB}^{t \mathrm{Bu}} \mathrm{N}, \mathrm{I}^{*}\right) \mathrm{Ti}(\mathrm{Cl}) \mathrm{CH}_{2} \mathrm{SiMe}_{3}$ are shown in Figure 2.2.

In addition to the resonances that are attributable to the sMAO support, resonances at approximately 20 and $30 \mathrm{ppm}$ correspond to the $\mathrm{I}^{*}-\mathrm{Me}$ and $\mathrm{N}-{ }^{t} \mathrm{Bu}$ resonances of the supported complex respectively. The quaternary resonances of the $I^{*}$ ring are combined with the resonance of sMAO at 125-140 ppm.

In all complexes, there is a resonance in the region of 50 to $60 \mathrm{ppm}$, in good agreement with the Ti-Me resonances in the ${ }^{13} \mathrm{C}\left\{{ }^{1} \mathrm{H}\right\}$ solution NMR spectrum of ${ }^{{ }^{\mathrm{Ne}}}{ }_{2} \mathrm{SB}\left({ }^{t \mathrm{Bu}} \mathrm{N}, \mathrm{I}^{*}\right) \mathrm{TiMe}_{2}$, which cannot be assigned to either the ligand or solid support. This can be attributed to methylation of the titanium centre upon immobilisation resulting in the cationic active species; this has been observed previously for other sMAO supported constrained geometry complexes, ${ }^{67}$ and has been hypothesised to occur both for sMAO supported complexes, and in solution when metallocene complexes are activated with a MAO cocatalyst. ${ }^{83}$ 


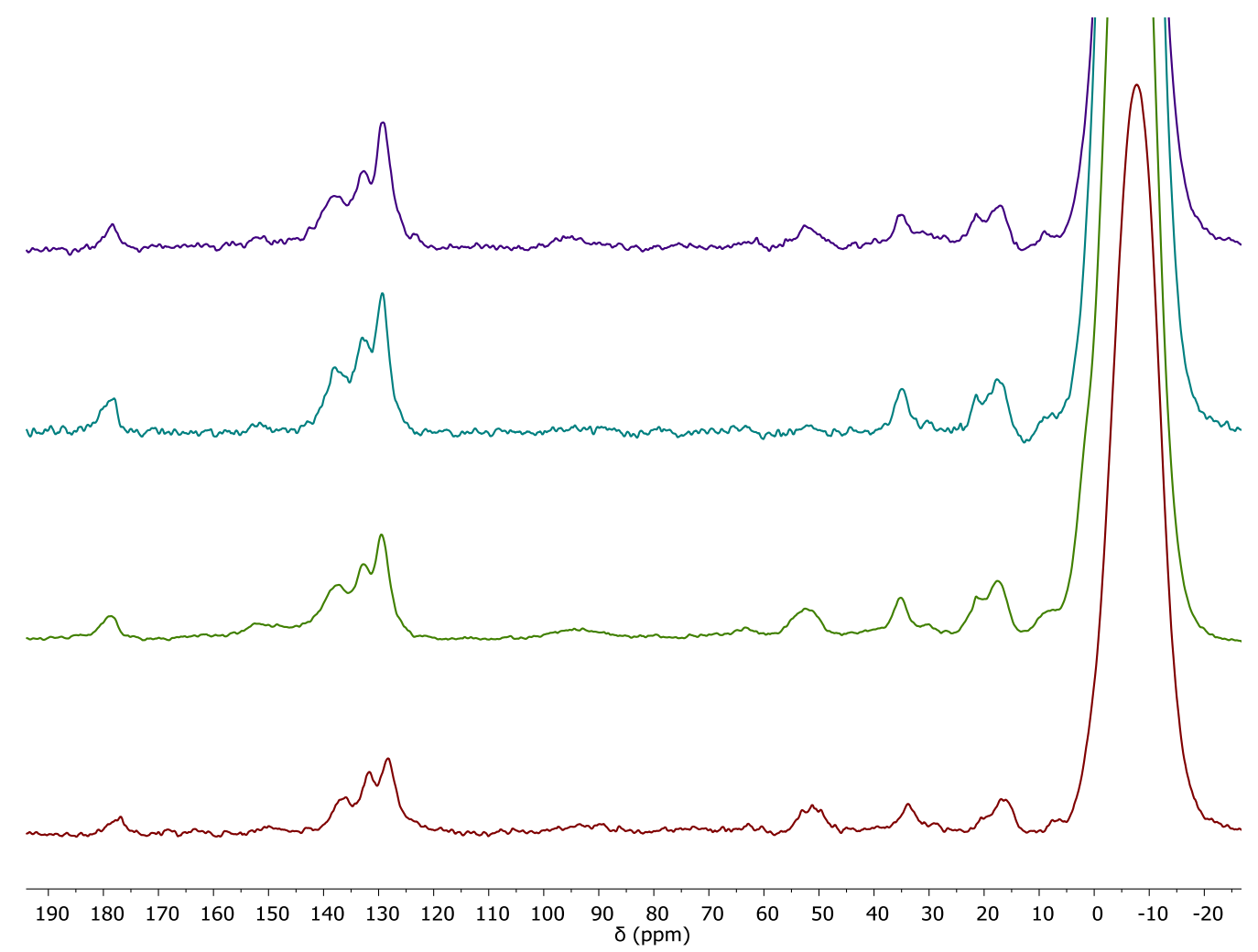

Figure 2.2. ${ }^{13} \mathrm{C}$ CP-MAS NMR spectra of (purple) sMAO- ${ }^{{ }^{2}}{ }_{2} \mathrm{SB}\left({ }^{t \mathrm{Bu}} \mathrm{N}, \mathrm{I}^{*}\right) \mathrm{Ti}\left(\mathrm{CH}_{2} \mathrm{Ph}\right)_{2}$, (blue)

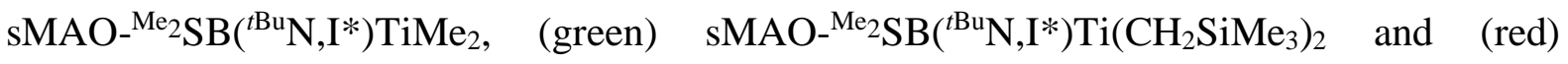
sMAO- ${ }^{\mathrm{Me}_{2}} \mathrm{SB}\left({ }^{t \mathrm{Bu}} \mathrm{N}, \mathrm{I}^{*}\right) \mathrm{Ti}(\mathrm{Cl}) \mathrm{CH}_{2} \mathrm{SiMe}_{3}$.

All supported complexes show a broad resonance in the ${ }^{27} \mathrm{Al}$ DP-MAS hahnecho NMR spectrum, indicating the highly amorphous nature of the sMAO support. In the ${ }^{29} \mathrm{Si} \mathrm{CP}-\mathrm{MAS}$ NMR spectrum, the complexes all show a resonance at approximately $-19 \mathrm{ppm}$, corresponding to ansa-bridging silicon in the ligand backbone. In addition, the ${ }^{29} \mathrm{Si}$ NMR spectra of both sMAO- ${ }^{\mathrm{Me}_{2}} \mathrm{SB}\left({ }^{t \mathrm{Bu}} \mathrm{N}, \mathrm{I}^{*}\right) \mathrm{Ti}\left(\mathrm{CH}_{2} \mathrm{SiMe}_{3}\right)_{2}$ and $\mathrm{sMAO}-{ }^{\mathrm{Me}}{ }_{2} \mathrm{SB}\left({ }^{t \mathrm{Bu}} \mathrm{N}, \mathrm{I}^{*}\right) \mathrm{Ti}(\mathrm{Cl}) \mathrm{CH}_{2} \mathrm{SiMe}_{3}$ have an extra resonance at 0.38 and -0.05 ppm respectively (Figures S2.34 and S2.37); we propose that this is attributable to the $-\mathrm{CH}_{2} \mathrm{SiMe}_{3}$ initiator groups that remain bound to the surface of the sMAO particle once the metal centre has been methylated. ICP has been carried out for the complex sMAO- ${ }^{\mathrm{Me}_{2}} \mathrm{SB}\left({ }^{(\mathrm{Bu}} \mathrm{N}, \mathrm{I}^{*}\right) \mathrm{TiCl}_{2}$ previously, and results show complete immobilisation in an $[\mathrm{Al}]_{0}:[\mathrm{Ti}]_{0}$ ratio of $200: 1$, and no leaching is observed over 3 hours of heating in slurry. ${ }^{67}$ 


\subsection{Slurry-phase ethylene homopolymerisation}

\subsubsection{Effect of the leaving group on slurry-phase ethylene polymerisation}

Solid polymethylaluminoxane immobilised ${ }^{\mathrm{Me}_{2}} \mathrm{SB}\left({ }^{t \mathrm{Bu}} \mathrm{N}, \mathrm{I}^{*}\right) \mathrm{TiR}_{2}\left(\mathrm{R}=\mathrm{Me}, \mathrm{CH}_{2} \mathrm{SiMe}_{3}\right.$ or $\left.\mathrm{CH}_{2} \mathrm{Ph}\right)$ and ${ }^{\mathrm{Me}_{2}} \mathrm{SB}\left({ }^{t \mathrm{Bu}} \mathrm{N}, \mathrm{I}^{*}\right) \mathrm{Ti}(\mathrm{Cl}) \mathrm{CH}_{2} \mathrm{SiMe}_{3}$ catalysts were tested for their ethylene homopolymerisation activity in the slurry phase (Figure 2.3, Tables S3.1 and S3.2).
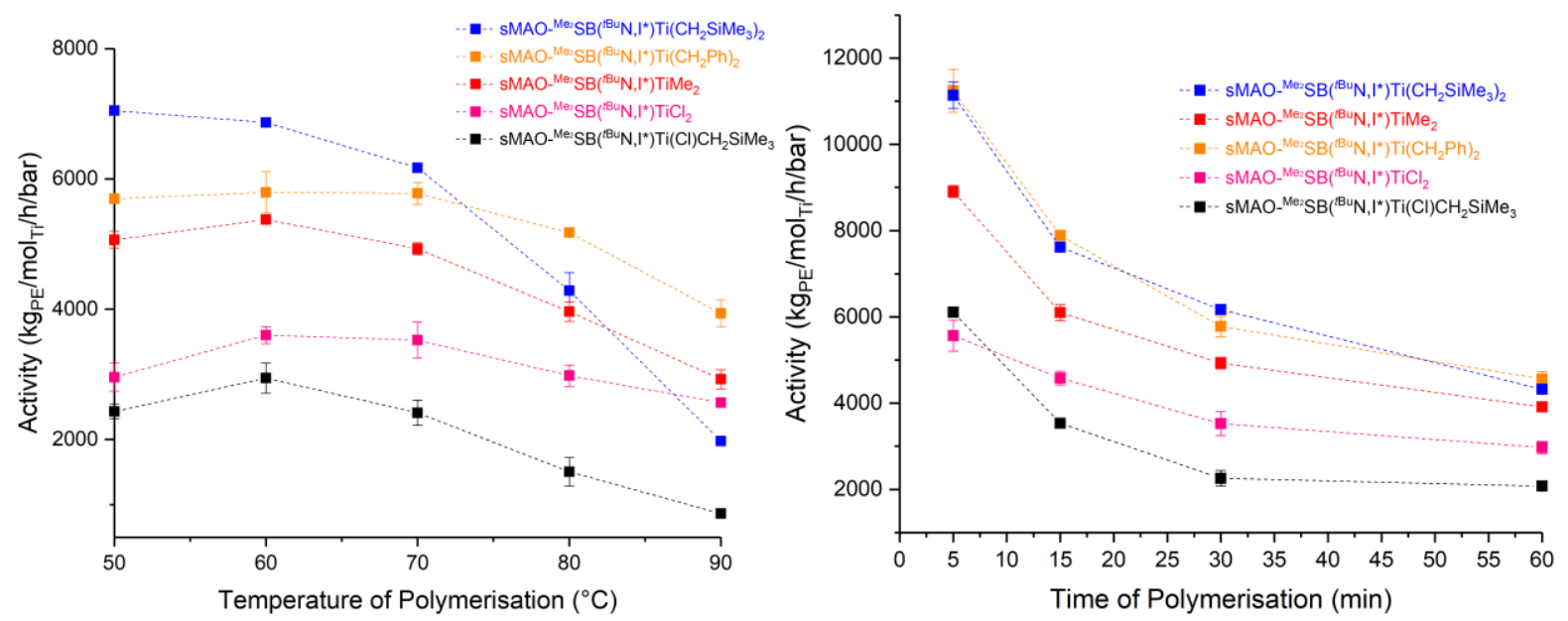

Figure 2.3. Ethylene polymerisation activities for $\mathrm{SMAO}-{ }^{\mathrm{Me}}{ }_{2} \mathrm{SB}\left({ }^{t \mathrm{Bu}} \mathrm{N}, \mathrm{I}^{*}\right) \mathrm{Ti}(\mathrm{Cl}) \mathrm{CH}_{2} \mathrm{SiMe}_{3}$ and sMAO- ${ }^{\mathrm{Me}_{2}} \mathrm{SB}\left({ }^{t \mathrm{Bu}} \mathrm{N}, \mathrm{I}^{*}\right) \mathrm{TiR}_{2}\left(\mathrm{R}=\mathrm{Me}, \mathrm{CH}_{2} \mathrm{Ph}\right.$ and $\left.\mathrm{CH}_{2} \mathrm{SiMe}_{3}\right)$. Polymerisation conditions (left): $10 \mathrm{mg}$ catalyst, 2 bar ethylene, $50 \mathrm{~mL}$ hexane, $150 \mathrm{mg}$ TiBA and 30 minutes. Polymerisation conditions (right): $10 \mathrm{mg}$ catalyst, 2 bar ethylene, $50 \mathrm{~mL}$ hexane, $150 \mathrm{mg}$ TiBA and $70{ }^{\circ} \mathrm{C}$.

Figure 2.3 shows the ethylene homopolymerisation activities between 50 and $90{ }^{\circ} \mathrm{C}$, and at $70{ }^{\circ} \mathrm{C}$ between 5 minutes and 1 hour, when compared with the activities of sMAO- ${ }^{\mathrm{Me}_{2}} \mathrm{SB}\left({ }^{t \mathrm{Bu}} \mathrm{N}, \mathrm{I}^{*}\right) \mathrm{TiCl}_{2} .{ }^{67}$ At $60{ }^{\circ} \mathrm{C}$, the dialkyl complexes exhibit significantly higher polymerisation activities (6865, 5792 and $5375 \mathrm{~kg} \mathrm{PE}_{\mathrm{PE}} / \mathrm{mol}_{\mathrm{Ti}} / \mathrm{h} / \mathrm{bar}$ for the sMAO- ${ }^{\mathrm{Me}_{2}} \mathrm{SB}\left({ }^{t \mathrm{Bu}} \mathrm{N}, \mathrm{I}^{*}\right) \mathrm{Ti}\left(\mathrm{CH}_{2} \mathrm{SiMe}_{3}\right)_{2}, \quad$ sMAO- ${ }^{\mathrm{Me}}{ }_{2} \mathrm{SB}\left({ }^{t \mathrm{Bu}} \mathrm{N}, \mathrm{I}^{*}\right) \mathrm{Ti}\left(\mathrm{CH}_{2} \mathrm{Ph}\right)_{2} \quad$ and sMAO- ${ }^{\mathrm{Me}_{2} \mathrm{SB}}\left({ }^{t \mathrm{Bu}} \mathrm{N}, \mathrm{I}^{*}\right) \mathrm{TiMe}_{2}$ complexes respectively) than that of $\mathrm{SMAO}-{ }^{\mathrm{Me}} 2 \mathrm{SB}\left({ }^{t \mathrm{Bu}} \mathrm{N}, \mathrm{I}^{*}\right) \mathrm{TiCl}_{2}$ (3602 kg $\left.\mathrm{Pg}_{\mathrm{PE}} / \mathrm{mol}_{\mathrm{Ti}} / \mathrm{h} / \mathrm{bar}\right)$ and $\left.\mathrm{sMAO}-{ }^{\mathrm{Me}_{2}} \mathrm{SB}{ }^{(\mathrm{Bu}} \mathrm{N}, \mathrm{I}^{*}\right) \mathrm{Ti}(\mathrm{Cl}) \mathrm{CH}_{2} \mathrm{SiMe}_{3}\left(2942 \mathrm{~kg}{ }_{\mathrm{PE}} / \mathrm{mol}_{\mathrm{Ti}} / \mathrm{h} / \mathrm{bar}\right)$ complexes. The effect of alkylation of metallocene type permethylindenyl complexes on polymerisation activity has been studied previously, ${ }^{35}$ with alkylation of the complexes leading to significantly enhanced polymerisation activities. The increase in polymerisation activities 
has been proposed to be due to a number of reasons: firstly, the alkyl initiator groups are electron donating, whilst the chloride group is electron withdrawing. Since it has previously been shown that addition of electron donating groups to an indenyl ring enhances polymerisation activity, and conversely electron withdrawing groups lead to decreased activities,${ }^{84}$ it has been proposed that a similar effect would be observed with variation of the initiator group. Secondly, it is thought that formation of the active species occurs by alkylation followed by abstraction to form a cationic species that is bound to the solid support. This is seen by reaction of ${ }^{\mathrm{Me}_{2}} \mathrm{SB}\left({ }^{(\mathrm{Bu}} \mathrm{N}, \mathrm{I}^{*}\right) \mathrm{TiCl}_{2}$ with methylaluminoxane (Figure S2.26) and so activation will be easier with an alkylated complex compared with a dichloride complex. Finally, the initiatior group likely remains bound to the surface of the solid support, and it is believed that this group exerts a secondary coordination influence on the active site of the catalyst. The initiator group also significantly effects the molecular weights $\left(M_{\mathrm{w}}\right)$ of the polymer that is formed (Figure 2.4), which is further evidence of the secondary coordination effect. Waymouth et al. have demonstrated how the oxidation state of the titanium metal centre can affect the rate of polymerisation as selectivities in copolymerisations ${ }^{85}$ it is possible that variation of the leaving group could lead to differing levels of $\mathrm{Ti}(\mathrm{III})$ and $\mathrm{Ti}(\mathrm{IV})$ species through ease of reduction by the sMAO support, and as such lead to differing levels of polymerisation activity.

In all cases, polymerisation activities decrease at higher temperatures, and this can be attributed to both decreased solubility of ethylene in hexanes and thermal decomposition of the catalyst. ${ }^{86}$ The alkylated complexes however show a decrease in polymerisation activities at $90{ }^{\circ} \mathrm{C}$ compared with $60^{\circ} \mathrm{C}$ when compared with sMAO- ${ }_{2}{ }_{2} \mathrm{SB}\left({ }^{t B u} \mathrm{~N}, \mathrm{I}^{*}\right) \mathrm{TiCl}_{2}$. Polymerisation activities decrease by 46 and $32 \%$ for $\mathrm{sMAO}_{-}{ }^{\mathrm{Me}}{ }_{2} \mathrm{SB}\left({ }^{t \mathrm{Bu}} \mathrm{N}, \mathrm{I}^{*}\right) \mathrm{TiMe}_{2} \quad(5375$ to $\left.2926 \mathrm{~kg} \mathrm{PE}_{\mathrm{PE}} / \mathrm{mol}_{\mathrm{Ti}} / \mathrm{h} / \mathrm{bar}\right)$ and sMAO- $\left.{ }^{\mathrm{Me}_{2}} \mathrm{SB}{ }^{t \mathrm{Bu}} \mathrm{N}, \mathrm{I}^{*}\right) \mathrm{Ti}\left(\mathrm{CH}_{2} \mathrm{Ph}\right)_{2}\left(5793\right.$ to $\left.3935 \mathrm{~kg}_{\mathrm{PE}} / \mathrm{mol}_{\mathrm{Ti}} / \mathrm{h} / \mathrm{bar}\right)$ 
respectively, whilst activities of $\mathrm{sMAO}-{ }^{\mathrm{Me}}{ }_{2} \mathrm{SB}\left({ }^{t \mathrm{Bu}} \mathrm{N}, \mathrm{I}^{*}\right) \mathrm{Ti}\left(\mathrm{CH}_{2} \mathrm{SiMe}_{3}\right)_{2} \quad(6866$ to $\left.1977 \mathrm{~kg} \mathrm{PE}_{\mathrm{PE}} / \mathrm{mol}_{\mathrm{Ti}} / \mathrm{h} / \mathrm{bar}\right) \quad$ and $\quad \mathrm{sMAO}-{ }^{\mathrm{Me}_{2}}{ }_{2 B}\left({ }^{t \mathrm{Bu}} \mathrm{N}, \mathrm{I}^{*}\right) \mathrm{Ti}(\mathrm{Cl}) \mathrm{CH}_{2} \mathrm{SiMe}_{3} \quad(2943 \quad$ to $\left.862 \mathrm{~kg} \mathrm{PE}_{\mathrm{PE}} / \mathrm{mol}_{\mathrm{Ti}} / \mathrm{h} / \mathrm{bar}\right)$ decrease by $71 \%$, the activity of $\mathrm{SMAO}^{\mathrm{Me}_{2}} \mathrm{SB}\left({ }^{t \mathrm{Bu}} \mathrm{N}, \mathrm{I}^{*}\right) \mathrm{TiCl}_{2}$ only decreases by $29 \%$ (3602 to $2565 \mathrm{~kg} \mathrm{PE}_{\mathrm{mol}} / \mathrm{mol}_{\mathrm{Ti}} / \mathrm{h} / \mathrm{bar}$ ).

Polymerisation studies were also conducted to investigate how polymerisation activities decreased with time at $70{ }^{\circ} \mathrm{C}$. When comparing the activities after 5 and 60 minutes, the polymerisation activity of sMAO- ${ }^{\mathrm{Me}_{2}} \mathrm{SB}\left({ }^{t \mathrm{Bu}} \mathrm{N}, \mathrm{I}^{*}\right) \mathrm{TiCl}_{2}$ decreases $(47 \%)$ by less than that of the SMAO- ${ }^{\mathrm{Me}_{2}} \mathrm{SB}\left({ }^{t \mathrm{Bu}} \mathrm{N}, \mathrm{I}^{*}\right) \mathrm{TiMe}_{2} \quad(56 \%), \quad$ SMAO- ${ }^{\mathrm{Me}}{ }_{2} \mathrm{SB}\left({ }^{t \mathrm{Bu}} \mathrm{N}, \mathrm{I}^{*}\right) \mathrm{Ti}\left(\mathrm{CH}_{2} \mathrm{Ph}\right)_{2} \quad$ (59\%), sMAO- ${ }^{\mathrm{Me}_{2}}{ }_{2} \mathrm{SB}\left({ }^{t \mathrm{Bu}} \mathrm{N}, \mathrm{I}^{*}\right) \mathrm{Ti}(\mathrm{Cl}) \mathrm{CH}_{2} \mathrm{SiMe}_{3} \quad(66 \%)$ and $\quad \mathrm{sMAO}-{ }^{\mathrm{Me}_{2}} \mathrm{SB}\left({ }^{(\mathrm{Bu}} \mathrm{N}, \mathrm{I}^{*}\right) \mathrm{Ti}\left(\mathrm{CH}_{2} \mathrm{SiMe}_{3}\right)_{2}$ (61\%) catalysts. These decreases in activity are caused both by catalyst decomposition but also the polymer templating effect ${ }^{44}$ which results in blocked active sites that results in decreased activities, and also the polymer taking on the form of discrete 'popcorn-shaped' particles, mimicking that of the solid support. ${ }^{35,59}$

Gel permeation chromatography (GPC) studies also demonstrate the effect of the leaving group on the polymer properties (Figure 2.4, Figure S3.14). Polymer molecular weight distributions $\left(M_{\mathrm{w}} / M_{\mathrm{n}}\right)$ are in the range 3.5-6.0. $\mathrm{sMAO}^{\mathrm{Me}}{ }_{2} \mathrm{SB}\left({ }^{\mathrm{B} u} \mathrm{~N}, \mathrm{I}^{*}\right) \mathrm{Ti}(\mathrm{Cl}) \mathrm{CH}_{2} \mathrm{SiMe}_{3}$ and sMAO- ${ }^{\mathrm{Me}_{2} \mathrm{SB}}\left({ }^{t \mathrm{Bu}} \mathrm{N}, \mathrm{I}^{*}\right) \mathrm{Ti}\left(\mathrm{CH}_{2} \mathrm{SiMe}_{3}\right)_{2}$ produce polymer with much higher molecular weights (1509 and $1860 \mathrm{kDa}$ at $50{ }^{\circ} \mathrm{C}$ respectively) compared with 654,877 and $979 \mathrm{kDa}$ for

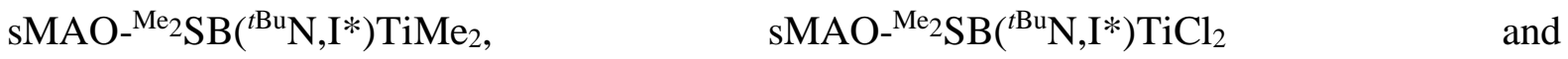
sMAO- ${ }^{{ }^{\mathrm{Ne}}} 2 \mathrm{SB}\left({ }^{t \mathrm{Bu}} \mathrm{N}, \mathrm{I}^{*}\right) \mathrm{Ti}\left(\mathrm{CH}_{2} \mathrm{Ph}\right)_{2}$ complexes. This highlights that the leaving group still has an effect on the polymerisation mechanism, further suggesting that the initiator group remains bound to the solid support surface and exerts a secondary coordination influence. The decrease in polymer molecular weight with increased temperature is expected, and has previously been observed for a variety of solid supported catalysts. ${ }^{35,46}$ At higher polymerisation temperatures, 
the system has more energy to overcome the greater activation barrier of chain termination relative to the barrier of propagation, hence resulting in lower polymer molecular weights. $M_{\mathrm{w}} / M_{\mathrm{n}}$ values have also been shown to decrease at higher ethylene pressures, presumably as the higher ethylene pressure leads to improved control of the polymerisation reaction.

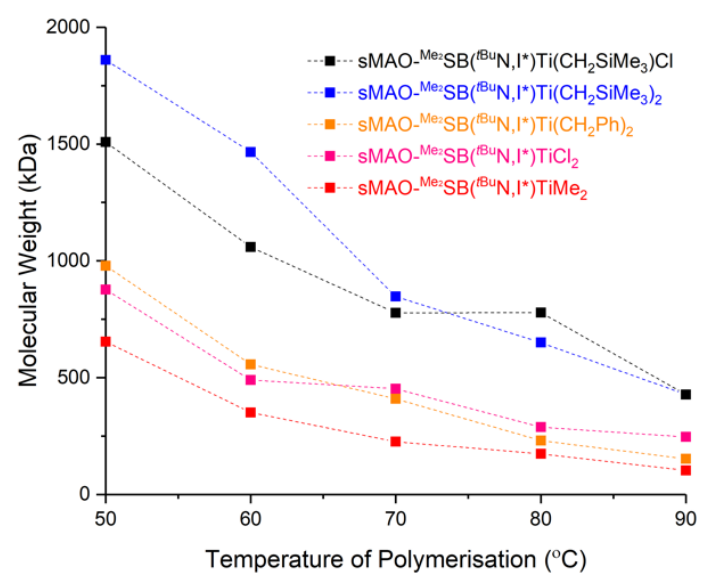

Figure 2.4. Molecular weights of the polyethylenes produced for the complexes sMAO- ${ }^{\mathrm{Me}_{2}}{ }_{\mathrm{SB}}\left({ }^{t \mathrm{Bu}} \mathrm{N}, \mathrm{I}^{*}\right) \mathrm{Ti}(\mathrm{Cl}) \mathrm{CH}_{2} \mathrm{SiMe}_{3}$ and sMAO- ${ }^{\mathrm{Me}_{2}} \mathrm{SB}\left({ }^{t \mathrm{Bu}} \mathrm{N}, \mathrm{I}^{*}\right) \mathrm{TiR}_{2}\left(\mathrm{R}=\mathrm{Me}, \mathrm{CH}_{2} \mathrm{Ph}\right.$ and $\mathrm{CH}_{2} \mathrm{SiMe}_{3}$ ). Polymerisation conditions: $10 \mathrm{mg}$ catalyst, 2 bar ethylene, $50 \mathrm{~mL}$ hexane, $150 \mathrm{mg}$ TiBA and 30 minutes.

Scanning electron miscroscopy images show that the polyethylenes obtained using sMAO- ${ }^{\mathrm{Me}_{2}} \mathrm{SB}\left({ }^{t \mathrm{Bu}} \mathrm{N}, \mathrm{I}^{*}\right) \mathrm{TiR}_{2}\left(\mathrm{R}=\mathrm{Me}, \mathrm{CH}_{2} \mathrm{Ph}\right.$ and $\left.\mathrm{CH}_{2} \mathrm{SiMe}_{3}\right)$ possesss a "popcorn" morphology (mimicking the support), Figure 2.5.
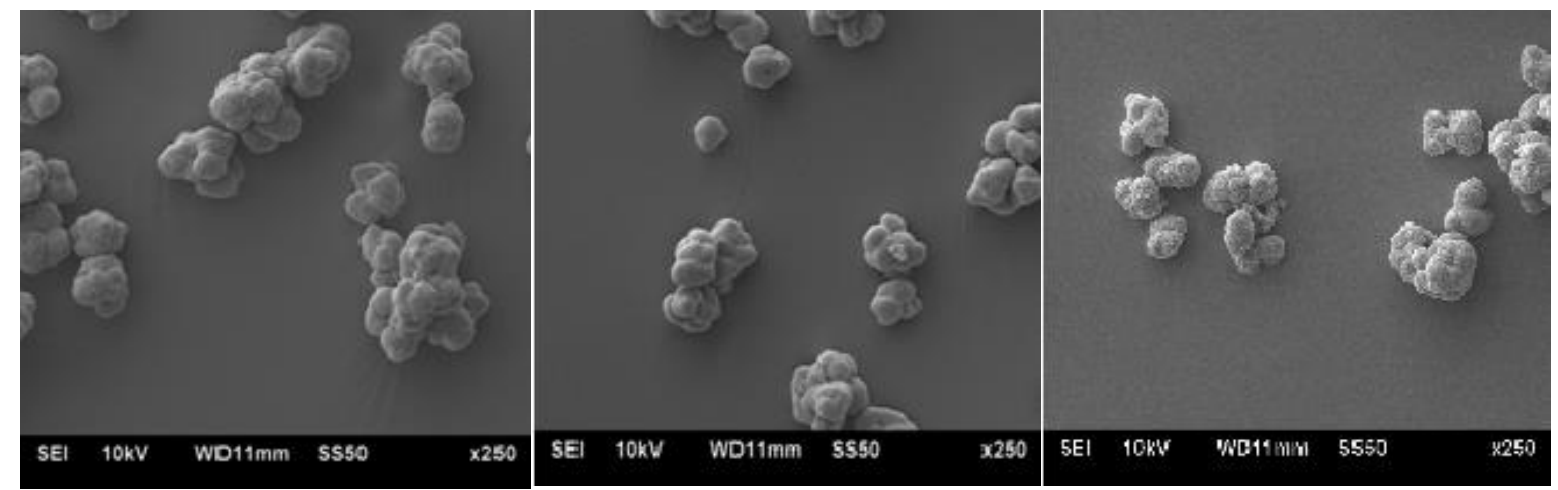

Figure 2.5. SEM images of polyethylene produced by a) $s M A O-{ }^{\mathrm{Me}_{2}} \mathrm{SB}\left({ }^{(\mathrm{Bu}} \mathrm{N}, \mathrm{I}^{*}\right) \mathrm{TiMe}_{2}$, b) sMAO- ${ }^{\mathrm{Me}_{2}} \mathrm{SB}\left({ }^{t \mathrm{Bu}} \mathrm{N}, \mathrm{I}^{*}\right) \mathrm{Ti}\left(\mathrm{CH}_{2} \mathrm{SiMe}_{3}\right)_{2}$ and c) $\mathrm{SMAO}-{ }^{\mathrm{Me}_{2}} \mathrm{SB}\left({ }^{t \mathrm{Bu}} \mathrm{N}, \mathrm{I}^{*}\right) \mathrm{Ti}\left(\mathrm{CH}_{2} \mathrm{Ph}\right)_{2}$. Polymerisation conditions: $10 \mathrm{mg}$ catalyst, 2 bar ethylene, $50 \mathrm{~mL}$ hexane, $150 \mathrm{mg}$ TiBA and 30 minutes. 


\subsubsection{Effect of the amido group on slurry phase ethylene polymerisation.}

We have previously reported the synthesis of a family of complexes ${ }^{\mathrm{Me}_{2}}{ }_{2} \mathrm{SB}\left({ }^{\mathrm{R}} \mathrm{N}, \mathrm{I}^{*}\right) \mathrm{TiCl}_{2}$, and their use as slurry phase ethylene polymerisation catalysts. ${ }^{67}$ These complexes demonstrated a clear trend of increased ethylene polymerisation activity with increased electron donating ability of the amido fragment which is compared with ${ }^{{ }^{\mathrm{Me}}}{ }_{2} \mathrm{SB}\left({ }^{\mathrm{Cy}} \mathrm{N}, \mathrm{I}^{*}\right) \mathrm{TiCl}_{2}$ (Figure 2.6).
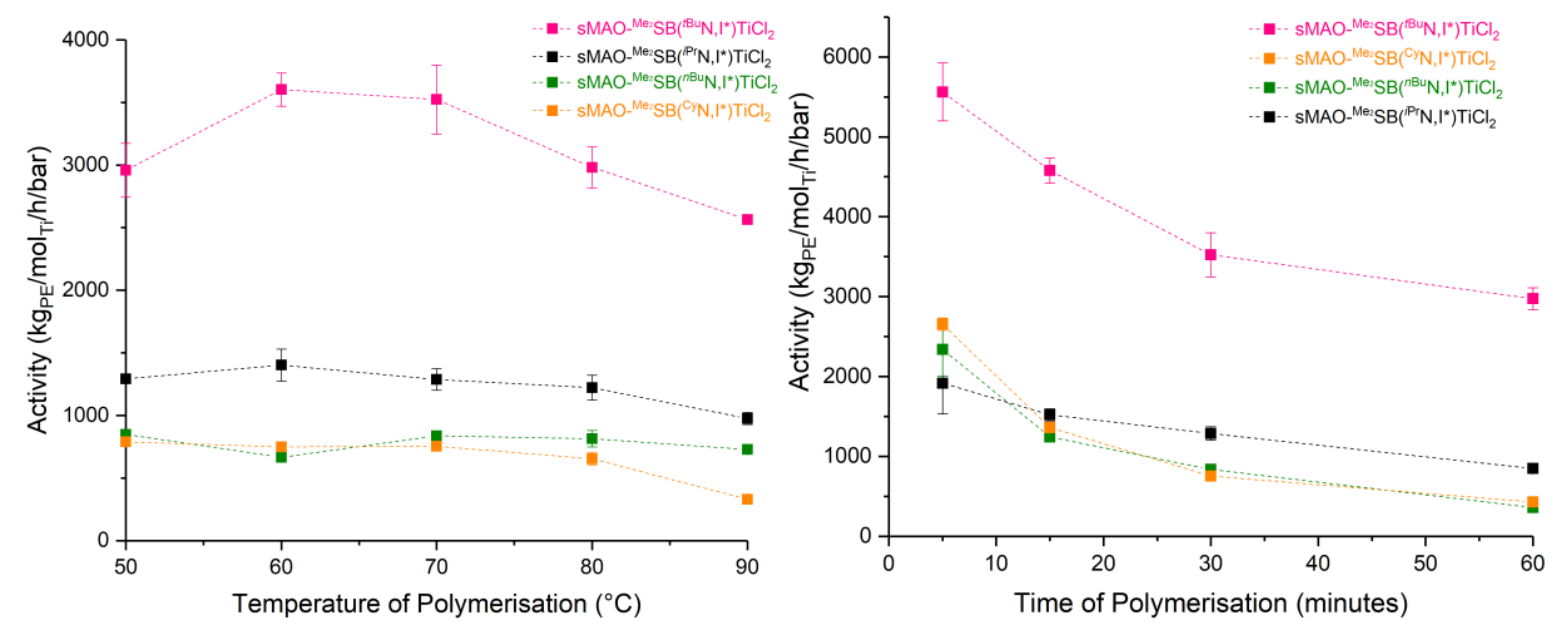

Figure 2.6. Slurry-phase ethylene polymerisation activities for $\mathrm{SMAO}-{ }^{\mathrm{Me}} 2 \mathrm{SB}\left({ }^{\mathrm{R}} \mathrm{N}, \mathrm{I} *\right) \mathrm{TiCl}_{2}$ $\left(\mathrm{R}={ }^{t} \mathrm{Bu},{ }^{i} \mathrm{Pr},{ }^{n} \mathrm{Bu}\right.$ and $\mathrm{Cy}$ ). Polymerisation conditions (left): $10 \mathrm{mg}$ catalyst, 2 bar ethylene, $50 \mathrm{~mL}$ hexane, $150 \mathrm{mg}$ TiBA and 30 minutes. Polymerisation conditions (right): $10 \mathrm{mg}$ catalyst, 2 bar ethylene, $50 \mathrm{~mL}$ hexane, $150 \mathrm{mg}$ TiBA and $70{ }^{\circ} \mathrm{C}$.

When compared with the previously synthesised complexes ${ }^{67}$ polymerisation activities of sMAO- ${ }^{\mathrm{Me}_{2}} \mathrm{SB}\left({ }^{\mathrm{Cy}} \mathrm{N}, \mathrm{I}^{*}\right) \mathrm{TiCl}_{2}$ are more comparable to those of $\mathrm{sMAO}-{ }^{\mathrm{Me}_{2}} \mathrm{SB}\left({ }^{n \mathrm{Bu}} \mathrm{N}, \mathrm{I}^{*}\right) \mathrm{TiCl}_{2}$ $\left(848 \mathrm{~kg}_{\mathrm{PE}} / \mathrm{mol}_{\mathrm{Ti}} / \mathrm{h} / \mathrm{bar}\right.$ after 30 minutes at $\left.50{ }^{\circ} \mathrm{C}\right)$ than that of $\mathrm{sMAO}-{ }^{\mathrm{Me}_{2}}{ }_{\mathrm{SB}}\left({ }^{i \mathrm{Pr}} \mathrm{N}, \mathrm{I}^{*}\right) \mathrm{TiCl}_{2}$ $\left(1402 \mathrm{~kg} \mathrm{PE}_{\mathrm{mol}} / \mathrm{hi} / \mathrm{bar}\right.$ after 30 minutes at $\left.60^{\circ} \mathrm{C}\right)$, with a maximum activity of $788 \mathrm{~kg} g_{\mathrm{PE}} / \mathrm{mol}_{\mathrm{Ti}} / \mathrm{h} / \mathrm{bar}$ after 30 minutes at $50{ }^{\circ} \mathrm{C}$. The molecular weights $\left(M_{\mathrm{w}}\right)$ of the polymers produced were determined by GPC (Figure 2.7). Polymer molecular weights decrease with increased polymerisation temperature ( 868 to $247 \mathrm{kDa}$ ), due to the relative rates of chain propagation and termination changing with temperature, ${ }^{87}$ and chain transfer reactions increasing at higher temperatures. ${ }^{88}$ In addition, there are greater values of polydispersities $\left(M_{\mathrm{w}} / M_{\mathrm{n}}\right)$ for the less active catalysts, at $70{ }^{\circ} \mathrm{C}, M_{\mathrm{w}} / M_{\mathrm{n}}$ values for $\mathrm{SMAO}-{ }^{\mathrm{Me}}{ }_{2} \mathrm{SB}\left({ }^{t \mathrm{Bu}} \mathrm{N}, \mathrm{I}^{*}\right) \mathrm{TiCl}_{2}$ is 
3.9 compared with 8.4, 7.6 and 5.7 for sMAO- ${ }^{\mathrm{Me}} 2 \mathrm{SB}\left({ }^{\mathrm{Cy}} \mathrm{N}, \mathrm{I}^{*}\right) \mathrm{TiCl}_{2}, \mathrm{sMAO}{ }^{\mathrm{Me}_{2}}{ }_{\mathrm{SB}}\left({ }^{i \mathrm{Pr}} \mathrm{N}, \mathrm{I}^{*}\right) \mathrm{TiCl}_{2}$ and $\mathrm{sMAO}-{ }^{\mathrm{Me}_{2}} \mathrm{SB}\left({ }^{n \mathrm{Bu}} \mathrm{N}, \mathrm{I} *\right) \mathrm{TiCl}_{2}$ respectively.

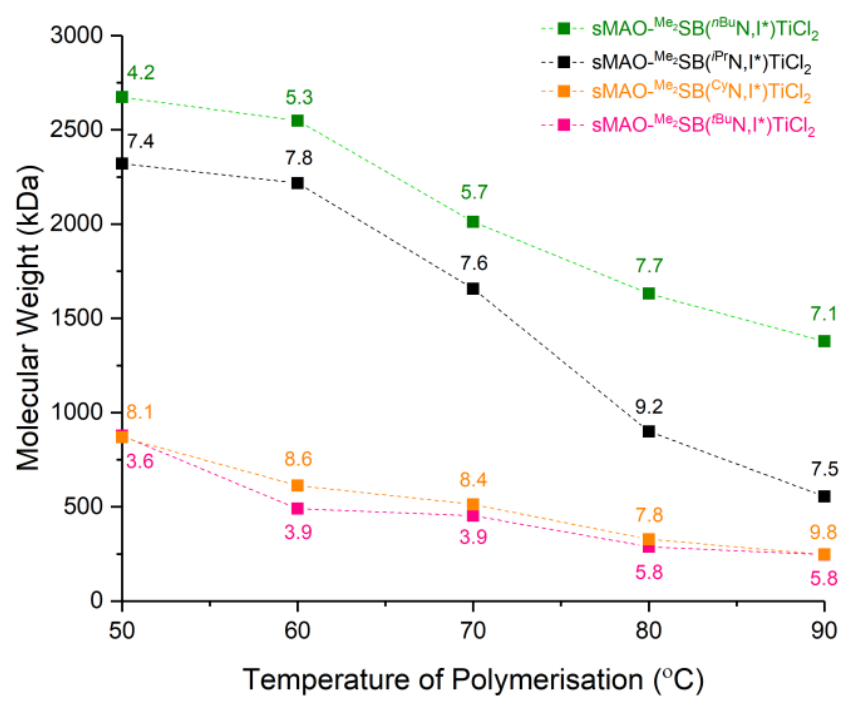

Figure 2.7. Molecular weights and polydispersities of the polyethylenes produced for the complexes sMAO- ${ }^{\mathrm{Me}_{2}} \mathrm{SB}\left({ }^{\mathrm{R}} \mathrm{N}, \mathrm{I}^{*}\right) \mathrm{TiCl}_{2}\left(\mathrm{R}={ }^{t} \mathrm{Bu},{ }^{i} \mathrm{Pr},{ }^{n} \mathrm{Bu}\right.$ and $\left.\mathrm{Cy}\right)$. Polymerisation conditions: $10 \mathrm{mg}$ catalyst, 2 bar ethylene, $50 \mathrm{~mL}$ hexane, $150 \mathrm{mg}$ TiBA and 30 minutes. $M_{\mathrm{w}} / M_{\mathrm{n}}$ values given.

\subsubsection{Effect of variation of the permethylindenyl ligand, ansa bridge and metal centre}

on slurry-phase ethylene polymerisation.

sMAO- $\left.{ }^{\mathrm{Me}_{2}} \mathrm{SB}^{t \mathrm{Bu}} \mathrm{N},{ }^{3-\mathrm{R}} \mathrm{I}^{*}\right) \mathrm{TiCl}_{2} \quad(\mathrm{R}=\mathrm{Me} \quad$ and $\quad \mathrm{Et}), \quad$ sMAO- ${ }^{\mathrm{Me}, \mathrm{Pr}} \mathrm{SB}\left({ }^{t \mathrm{Bu}} \mathrm{N}, \mathrm{I}^{*}\right) \mathrm{TiCl}_{2}, \quad$ and sMAO- ${ }^{{ }^{e}}{ }_{2} \mathrm{SB}\left({ }^{t B u} \mathrm{~N}, I^{*}\right) \mathrm{ZrCl}_{2}$ were tested for slurry phase ethylene homopolymerisation (Figure
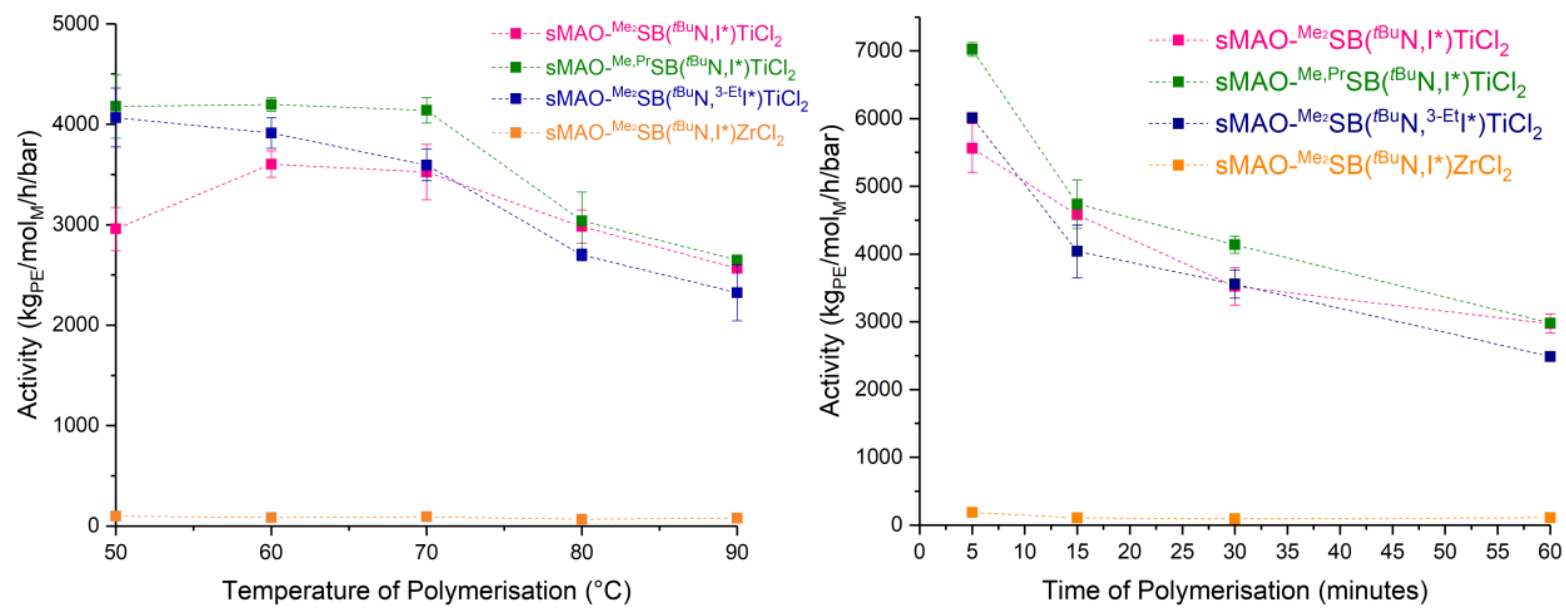
Figure 2.8. Slurry-phase ethylene polymerisation activities for $\mathrm{SMAO}-{ }^{\mathrm{Me}} 2 \mathrm{SB}\left({ }^{(\mathrm{Bu}} \mathrm{N},{ }^{3-\mathrm{Et}} \mathrm{I}^{*}\right) \mathrm{TiCl}_{2}$, sMAO- ${ }^{\mathrm{Me}, \mathrm{R}} \mathrm{SB}\left({ }^{\mathrm{tBu}} \mathrm{N}, \mathrm{I}^{*}\right) \mathrm{TiCl}_{2}(\mathrm{R}=\mathrm{Me}$ and $\mathrm{Pr})$ and $\mathrm{sMAO}-{ }^{\mathrm{Me}} 2 \mathrm{SB}\left({ }^{\mathrm{tBu}} \mathrm{N}, \mathrm{I}^{*}\right) \mathrm{ZrCl}_{2}$. Polymerisation conditions (left): $10 \mathrm{mg}$ catalyst, 2 bar ethylene, $50 \mathrm{~mL}$ hexane, $150 \mathrm{mg}$ TiBA and 30 minutes. Polymerisation conditions (right): $10 \mathrm{mg}$ catalyst, 2 bar ethylene, $50 \mathrm{~mL}$ hexane, $150 \mathrm{mg}$ TiBA and $70{ }^{\circ} \mathrm{C}$.

At temperatures below $70{ }^{\circ} \mathrm{C}$, sMAO- ${ }^{\mathrm{Me}} 2 \mathrm{SB}\left({ }^{t \mathrm{Bu}} \mathrm{N},{ }^{3-\mathrm{Et}} \mathrm{I}^{*}\right) \mathrm{TiCl}_{2}$ exhibits higher activities than sMAO- ${ }^{\mathrm{Me}_{2}} \mathrm{SB}\left({ }^{t \mathrm{Bu}} \mathrm{N}, \mathrm{I}^{*}\right) \mathrm{TiCl}_{2}$, with a maximum activity of $4067 \mathrm{~kg} \mathrm{PE} / \mathrm{mol}_{\mathrm{Ti}} / \mathrm{h} / \mathrm{bar}$ after 30 minutes at $50{ }^{\circ} \mathrm{C}$. This increase in activity initially appears unexpected, since the analogous family of catalysts sMAO- ${ }^{\mathrm{Me}_{2}} \mathrm{SB}\left({ }^{t \mathrm{Bu}_{2}} \mathrm{Flu},{ }^{3-\mathrm{R}} \mathrm{I}^{*}\right) \mathrm{ZrCl}_{2}$ shows decreases in activity for the 3 -ethyl complex relative to the permethylindenyl complex (4963 and $\left.6755 \mathrm{~kg} \mathrm{PE}_{\mathrm{Pol}} / \mathrm{mol}_{\mathrm{Zr}} / \mathrm{h} / \mathrm{bar}\right){ }^{59}$ However, considering that the CGC complexes have two fewer valence electron than these complexes, ${ }^{2,89}$ the additional inductive effect of the ethyl group relative the methyl is likely to enhance polymerisation activity, similarly to what has been observed for amido group variation. Similarly to sMAO- ${ }^{\mathrm{Me}_{2}}{ }_{\mathrm{SBB}}\left({ }^{\mathrm{tBu}} 2 \mathrm{Flu},{ }^{3-\mathrm{R}} \mathrm{I}^{*}\right) \mathrm{ZrCl}_{2}$ catalysts, there are much greater decreases in polymerisation activities at higher temperatures for $\mathrm{SMAO}-{ }^{\mathrm{Me}} 2 \mathrm{SB}\left({ }^{t \mathrm{Bu}} \mathrm{N},{ }^{3-\mathrm{Et}} \mathrm{I}^{*}\right) \mathrm{TiCl}_{2}$ (3913 and $2323 \mathrm{~kg}$ PE $/ \mathrm{mol}_{\mathrm{Ti}} / \mathrm{h} / \mathrm{bar}$ for 60 and $90{ }^{\circ} \mathrm{C}$ ) compared with sMAO- ${ }^{\mathrm{Me}}{ }_{2} \mathrm{SB}\left({ }^{t \mathrm{Bu}} \mathrm{N}, \mathrm{I}^{*}\right) \mathrm{TiCl}_{2}$ (3602 and $2565 \mathrm{~kg} \mathrm{PE}_{\mathrm{PE}} / \mathrm{mol}_{\mathrm{Ti}} / \mathrm{h} / \mathrm{bar}$ for 60 and $90{ }^{\circ} \mathrm{C}$ ), indicating a decrease in thermal stability of these 3-ethylpentamethyindenyl complexes relative to the permethylindenyl analogues.

sMAO- ${ }^{\mathrm{Me}, \mathrm{Pr}_{\mathrm{PB}}} \mathrm{SB}\left({ }^{t \mathrm{Bu}} \mathrm{N}, \mathrm{I}^{*}\right) \mathrm{TiCl}_{2}$ also show higher activities than $\left.\mathrm{sMAO}-{ }^{\mathrm{Me}_{2}} \mathrm{SB}{ }^{t \mathrm{Bu}} \mathrm{N}, \mathrm{I}^{*}\right) \mathrm{TiCl}_{2}$ at all temperatures with a maximum value of $4197 \mathrm{~kg} \mathrm{PE}_{\mathrm{PE}} / \mathrm{mol}_{\mathrm{Ti}} / \mathrm{h} / \mathrm{bar}$ after 30 minutes at $60{ }^{\circ} \mathrm{C}$. This is in contrast to the related complexes sMAO- ${ }^{\mathrm{R}_{1}, \mathrm{R}_{2}} \mathrm{SB}\left({ }^{\mathrm{tBu}}{ }_{2} \mathrm{Flu}, \mathrm{I}^{*}\right) \mathrm{ZrCl}_{2}\left(\mathrm{R}_{1}=\mathrm{R}_{2}=\mathrm{Me}\right.$, Et, and $\mathrm{R}_{1}=\mathrm{Me}, \mathrm{R}_{2}=\operatorname{Pr}$ ) where the dimethylsilyl bridged complex shows higher activities (6755 kg $\left.\mathrm{PE}_{\mathrm{P}} / \mathrm{mol}_{\mathrm{Zr}} / \mathrm{h} / \mathrm{bar}\right)$ compared to the diethylsilyl bridged complex $\left(5550 \mathrm{~kg} \mathrm{PE}_{\mathrm{P}} / \mathrm{mol} \mathrm{zr} / \mathrm{h} / \mathrm{bar}\right)$ and the methylpropylsilyl bridged complex $(5059 \mathrm{~kg} \mathrm{PE} / \mathrm{mol} \mathrm{Zr} / \mathrm{h} / \mathrm{bar}){ }^{59}$ Alt and co-workers have previously reported the synthesis of constrained geometry complexes of the form ${ }^{\mathrm{Me}, \mathrm{R}} \mathrm{SB}\left({ }^{t \mathrm{Bu}} \mathrm{N},{ }^{3-\mathrm{R}} \mathrm{Cp}\right) \mathrm{TiCl}_{2}$ and ${ }^{\mathrm{Me}, \mathrm{R}} \mathrm{SB}\left({ }^{t \mathrm{Bu}} \mathrm{N},{ }^{3-\mathrm{R}} \mathrm{I}\right) \mathrm{TiCl}_{2}$, and shown that variation of $\mathrm{R}$ group lead 
to enhancements in polymerisation activity for $\mathrm{R}=$ vinyl compared with $\mathrm{R}=$ phenyl, likely due to the relative electron donating ability of the groups. ${ }^{11}$ Similarly for metallocene type complexes, work has been undertaken to investigate how the ansa bridge effects both polymerisation activity, but also stereospecificity in propylene polymerisation..$^{90-92}$

Pombeiro and co-workers have shown through variation of the 2- position of complexes ${ }^{{ }^{\mathrm{Me}}}{ }_{2} \mathrm{SB}\left({ }^{t \mathrm{Bu}} \mathrm{N},{ }^{2-\mathrm{R}} \mathrm{Cp}{ }^{*}\right) \mathrm{TiCl}_{2}$ that addition of alkyl groups, $\left(\mathrm{R}=\mathrm{Me},{ }^{n} \mathrm{Bu}\right)$ resulted in decreases in polymerisation activity relative to the ${ }^{\mathrm{Me}_{2}} \mathrm{SB}\left({ }^{t B u} \mathrm{~N},{ }^{2-\mathrm{H}} \mathrm{Cp} *\right) \mathrm{TiCl}_{2}$, when activated with an excess of MAO, whereas addition of a phenyl group in the 2- position $\left({ }^{\mathrm{Me}}{ }_{2} \mathrm{SB}\left({ }^{t \mathrm{Bu}} \mathrm{N},{ }^{2-\mathrm{Ph}} \mathrm{Cp} *\right) \mathrm{TiCl}_{2}\right.$ has been shown to increase polymerisation activity. ${ }^{93}$ Alt et al. proposed that this activity enhancement could be due to a spacer effect, whereby the phenyl group separates the bulky MAO anion from the catalytic species, $^{12}$ this effect has also been seen in ansa-bis(fluorenylidene)zirconium dichloride systems. $^{94}$ Conversely, with (3-R)-pentamethylindenyl complexes ${ }^{\mathrm{Me}_{2}} \mathrm{SB}\left({ }^{t \mathrm{Bu}} \mathrm{N}, \mathrm{I}^{*}\right) \mathrm{TiCl}_{2}$ and ${ }^{\mathrm{Me}_{2}} \mathrm{SB}\left({ }^{t \mathrm{Bu}} \mathrm{N},{ }^{3-\mathrm{Et}} \mathrm{I}^{*}\right) \mathrm{TiCl}_{2}$, this additional steric bulk has been contributed by the I* ring itself, we propose the addition of the 3-ethyl group, a methylpropylsilyl or diethylsilyl ansa-bridge will, through a balance of steric and electronic factors, enhance polymerisation activity through a directional and inductive effect of these groups.

Variation of the metal centre down group 4 from titanium to zirconium results in significant decreases in polymerisation activity, which is contrast to what has been observed for many metallocene type ethylene polymerisation catalysts, ${ }^{5}$ but is commonly observed for CGCs. ${ }^{13,95}$ DFT studies have shown that this decrease in polymerisation activity is attributable to the ethylene insertion step in the polymerisation mechanism, where the activation barrier for zirconium constrained geometry complexes is much greater than is observed for titanium analogues, resulting in slower polymerisation rates. ${ }^{96}$ The maximum activity after 30 minutes 
for $\mathrm{sMAO}-{ }^{\mathrm{Me}_{2}} \mathrm{SB}\left({ }^{\mathrm{tBu}} \mathrm{N}, \mathrm{I}^{*}\right) \mathrm{ZrCl}_{2}$ is $99 \mathrm{~kg} \mathrm{PE} / \mathrm{mol}_{\mathrm{Zr}} / \mathrm{h} / \mathrm{bar}$, and this 30 fold decrease in activity with respect to the titanium analogue is not uncommon for these complexes, with large decreases in activity observed for the $\mathrm{Cp}^{*}$ analogues when supported on silica and activated with MAO. ${ }^{95}$ Molecular weights $\left(M_{\mathrm{w}}\right)$ and polydispersities $\left(M_{\mathrm{w}} / M_{\mathrm{n}}\right)$ are given in Table 2.2 (Figure S3.13), whilst $\mathrm{SMAO}_{-}{ }^{\mathrm{Me}_{2}} \mathrm{SB}\left({ }^{t \mathrm{Bu}} \mathrm{N},{ }^{3-\mathrm{Et}}{ }^{*}\right) \mathrm{TiCl}_{2}$ gives lower molecular weight polyethylenes than the permethylindenyl complex. The narrow molecular weight distributions indicate controlled polymerisation with a single site catalytic species in both cases, this can also be observed in the ssNMR ${ }^{29} \mathrm{Si} \mathrm{CP}-\mathrm{MAS}$ spectrum of both catalysts where a single ${ }^{29} \mathrm{Si}$ resonance is observed in both cases (Figures S2.44). The complexes also produce higher molecular weight polyethylenes than comparable permethylindenyl complexes, such as sMAO- ${ }^{\mathrm{Me}_{2}} \mathrm{SB}\left(\mathrm{Cp}, \mathrm{I}^{*}\right) \mathrm{ZrCl}_{2} \quad(130 \mathrm{kDa})$, and sMAO-rac-SBI* $\mathrm{ZrCl}_{2} \quad(183 \mathrm{kDa})$ at $60{ }^{\circ} \mathrm{C},{ }^{35}$ presumably due to the more open coordination sphere of the metal centre for CGCs. ${ }^{1}$

The polyethylenes produced by $\mathrm{sMAO}-{ }^{\mathrm{Me}, \mathrm{Pr}} \mathrm{SB}\left({ }^{t \mathrm{Bu}} \mathrm{N}, \mathrm{I}^{*}\right) \mathrm{TiCl}_{2}$ exhibit much higher molecular weights than sMAO- ${ }^{\mathrm{Me}_{2}}{ }_{\mathrm{SB}}\left({ }^{\mathrm{tBu}} \mathrm{N}, \mathrm{I}^{*}\right) \mathrm{TiCl}_{2}$ with relatively low molecular weight distributions (3.7-4.3) being maintained throughout once again indicating a controlled single site nature of the ethylene polymerisation. At low temperatures, molecular weights are almost double, with a value of $1501 \mathrm{kDa}$ at $50{ }^{\circ} \mathrm{C}$.

Table 2.2 Molecular weights $\left(M_{\mathrm{w}}\right)$ and polydispersities $\left(M_{\mathrm{w}} / M_{\mathrm{n}}\right)$ of the polyethylenes produced for the complexes sMAO- ${ }^{\mathrm{Me}, \mathrm{R}} \mathrm{SB}\left({ }^{t \mathrm{Bu}} \mathrm{N},{ }^{3-\mathrm{R}} \mathrm{I}^{*}\right) \mathrm{TiCl}_{2}(\mathrm{R}=\mathrm{Me}$, Et and $\mathrm{Pr})$. Polymerisation conditions: $10 \mathrm{mg}$ catalyst, 2 bar ethylene, $50 \mathrm{~mL}$ hexane, $150 \mathrm{mg}$ TiBA and 30 minutes.

\begin{tabular}{|c|c|c|c|c|c|c|}
\hline Complex & \multicolumn{2}{|c|}{${ }^{\mathrm{Me}_{2}} \mathrm{SB}\left({ }^{t \mathrm{Bu}} \mathrm{N}, \mathrm{I}^{*}\right) \mathrm{TiCl}_{2}$} & \multicolumn{2}{|c|}{${ }^{\mathrm{Me}_{2}} \mathrm{SB}\left({ }^{t \mathrm{Bu}} \mathrm{N},{ }^{3-\mathrm{Et}} \mathrm{I}^{*}\right) \mathrm{TiCl}_{2}$} & \multicolumn{2}{|c|}{${ }^{\mathrm{Me}, \mathrm{Pr}} \mathrm{SB}\left({ }^{\mathrm{tBu}} \mathrm{N}, \mathrm{I}^{*}\right) \mathrm{TiCl}_{2}$} \\
\hline $\begin{array}{c}T \\
\left({ }^{\circ} \mathrm{C}\right)\end{array}$ & $\begin{array}{c}M_{\mathrm{w}} \\
(\mathrm{kDa})\end{array}$ & $M_{\mathrm{w}} / M_{\mathrm{n}}$ & $\begin{array}{c}M_{\mathrm{w}} \\
(\mathrm{kDa})\end{array}$ & $M_{\mathrm{w}} / M_{\mathrm{n}}$ & $\begin{array}{c}M_{\mathrm{w}} \\
(\mathrm{kDa})\end{array}$ & $M_{\mathrm{w}} / M_{\mathrm{n}}$ \\
\hline 50 & 881 & 3.6 & 598 & 3.7 & 1501 & 3.7 \\
\hline 60 & 490 & 3.9 & 505 & 3.3 & 1059 & 3.9 \\
\hline 70 & 474 & 3.9 & 276 & 4.9 & 777 & 3.9 \\
\hline 80 & 289 & 5.8 & 205 & 4.7 & 769 & 4.3 \\
\hline 90 & 246 & 5.8 & 168 & 4.5 & 428 & 4.0 \\
\hline
\end{tabular}




\subsection{Slurry-phase ethylene/1-hexene copolymerisation}

The effect of temperature on ethylene/1-hexene copolymerisation has been studied using sMAO- ${ }^{\mathrm{Me}_{2}} \mathrm{SB}\left({ }^{t B u} \mathrm{~N}, \mathrm{I}^{*}\right) \mathrm{TiCl}_{2}$. Copolymerisations were carried out for 30 minutes in a $150 \mathrm{~mL}$ ampoule with a sidearm with $0.156,0.312$ or $0.625 \mathrm{~mL}$ of 1 -hexene in $5 \mathrm{~mL}$ of hexanes that was added at the start of the polymerisation, a total volume of $50 \mathrm{~mL}$ hexanes, $10 \mathrm{mg}$ of

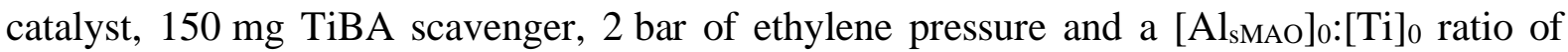
1:200. The temperature of polymerisation was varied from 30 to $90{ }^{\circ} \mathrm{C}$ and the results of these studies are shown in Figure 2.9.

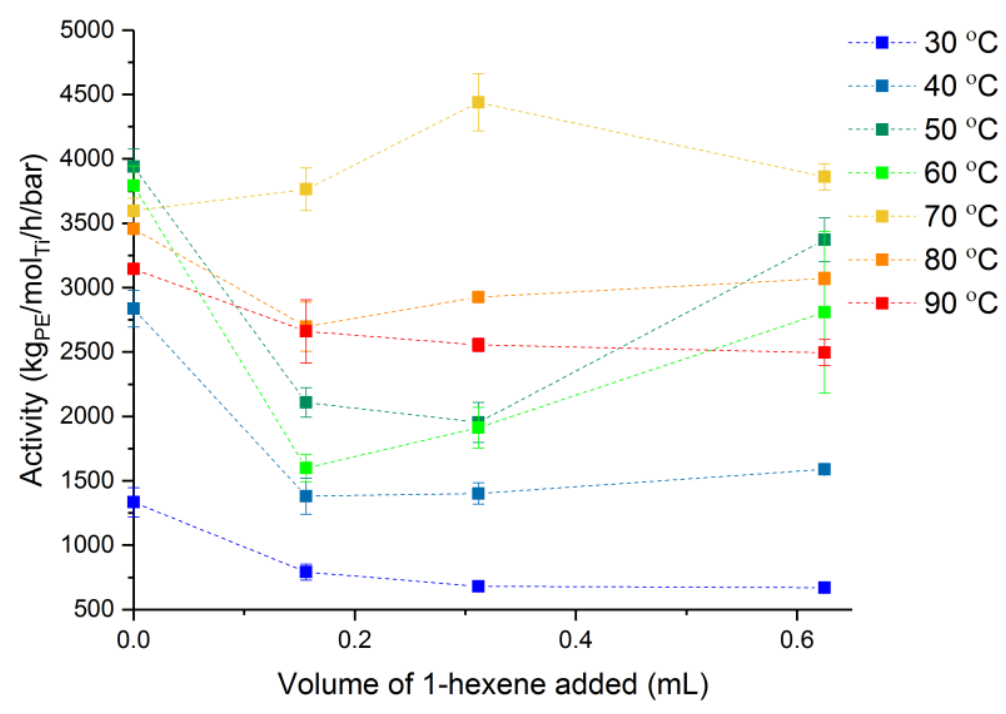

Figure 2.9. Slurry-phase ethylene copolymerisation activities for $\mathrm{SMAO}-{ }^{\mathrm{Me}} 2 \mathrm{SB}\left({ }^{t \mathrm{Bu}} \mathrm{N}, \mathrm{I}^{*}\right) \mathrm{TiCl}_{2}$. (Co)polymerisation conditions: $10 \mathrm{mg}$ catalyst, 2 bar ethylene, $0,0.156,0.312$ or $0.625 \mathrm{~mL}$ 1-hexene, $50 \mathrm{~mL}$ hexane, $150 \mathrm{mg}$ TiBA and 30 minutes.

At temperatures below $70{ }^{\circ} \mathrm{C}$, there are decreases in activity with addition of 1-hexene compared with homopolymerisation. This is likely to be due to a higher activation energy for chain propagation of an $\alpha$-olefin compared with ethylene, ${ }^{97}$ causing activities to be lower for copolymerisation than homopolymerisation. At 80 and $90{ }^{\circ} \mathrm{C}$, activities also decrease with addition of 1-hexene (from 3308 and $3010 \mathrm{~kg}_{\mathrm{PE}} / \mathrm{mol}_{\mathrm{Ti}} / \mathrm{h} / \mathrm{bar}$ for homopolymerisation to 2939 and $2388 \mathrm{~kg}_{\mathrm{PE}} / \mathrm{mol}_{\mathrm{Ti}} / \mathrm{h} / \mathrm{bar}$ with addition of $0.625 \mathrm{~mL}$ of 1 -hexene respectively), due to the 
exothermic spike leading to catalyst deactivation. At $70{ }^{\circ} \mathrm{C}$, activities increase with addition of 1-hexene from 3443 to $4248 \mathrm{~kg} \mathrm{PE}_{1} / \mathrm{mol}_{\mathrm{Ti}} / \mathrm{h} / \mathrm{bar}$ for increasing addition of 1-hexene, possibly due to the enthalpic barrier of 1-hexene insertion at low temperatures being overcome, ${ }^{97} 1$-hexene increasing ethylene solubility, ${ }^{98}$ and increased ability for monomer close approach to the catalyst site. $^{99}$ The uptake rate graphs show the relative ethylene uptake rates for (co)polymerisations at 70, 80 and $90{ }^{\circ} \mathrm{C}$ (Figure S3.4-S3.6).

The uptake rate plots indicate that there is not significantly greater catalyst deactivation in the copolymerisation reactions compared with the homopolymerisations, with uptake rates remaining constant through the polymerisations. At $70{ }^{\circ} \mathrm{C}$, with addition of $0.625 \mathrm{~mL}$ 1-hexene, an increase in uptake rate is observed after 750 seconds.

The polymers produced have been studied by differential scanning calorimetry (DSC) to determine polymer melt and crystallisation temperatures and enthalpies (Tables S3.4 and S3.5, and Figure 2.10). DSC is a common method of studying polymers of this type, as it gives an indication of the incorporation of comonomer into a polymer chain. ${ }^{100}$

With addition of 1-hexene, there are large decreases in all values measured across the temperature range. The increase in chain branching that occurs from 1-hexene incorporation into the polymer chain weakens the Van der Waals forces within the polymer. The broadening of the peaks with increased 1-hexene addition is caused by a decrease in polymer crystallinity and defective crystal formation. ${ }^{101}$

The levels of 1-hexene incorporation have been determined using high temperature ${ }^{13} \mathrm{C}\left\{{ }^{1} \mathrm{H}\right\}$ NMR spectroscopy, with the side chain resonances and carbon resonances in close proximity being assigned by comparison to literature values. ${ }^{102,103}$ It has previously been shown that for ethylene/1-octene copolymerisations, incorporation levels decrease with increased temperature 
of reaction. ${ }^{97}$ However, as is seen in Table 2.3, the levels of 1-hexene incorporation increase from $1.9 \%$ at $30{ }^{\circ} \mathrm{C}$ to $2.6 \%$ at $90{ }^{\circ} \mathrm{C}$.

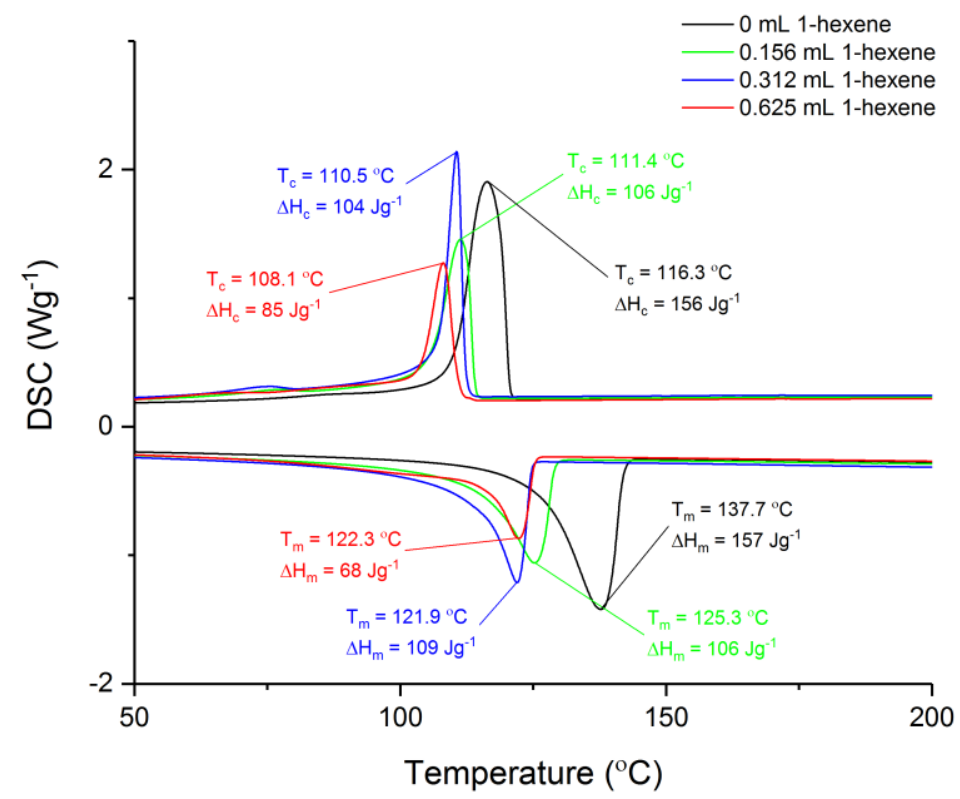

Figure 2.10. DSC plot for polymers produced by $\mathrm{sMAO}-{ }^{\mathrm{Me}}{ }_{2} \mathrm{SB}\left({ }^{t \mathrm{Bu}} \mathrm{N}, \mathrm{I}^{*}\right) \mathrm{TiCl}_{2}$ at $70{ }^{\circ} \mathrm{C}$ for $0 \mathrm{~mL}$ 1-hexene (black), $0.156 \mathrm{~mL} 1$-hexene (green), $0.312 \mathrm{~mL} \mathrm{1-hexene} \mathrm{(blue),} \mathrm{and} 0.625 \mathrm{~mL}$ 1-hexene (red).

Table 2.3. 1-hexene incorporation levels and melt temperatures $\left(T_{\mathrm{m}}\right)$ of the copolymers produced. (Co)polymerisation conditions: $10 \mathrm{mg}$ sMAO- ${ }^{\mathrm{Me}}{ }_{2} \mathrm{SB}\left({ }^{t \mathrm{Bu}} \mathrm{N}, \mathrm{I}^{*}\right) \mathrm{TiCl}_{2}, 2$ bar ethylene, $0,0.156,0.312$ or $0.625 \mathrm{~mL}$ 1-hexene, $50 \mathrm{~mL}$ hexane, $150 \mathrm{mg}$ TiBA and 30 minutes.

\begin{tabular}{c|c|cc|cc|cc}
$\begin{array}{c}\text { Vol. 1-hexene } \\
\text { added (mL) }\end{array}$ & 0 & \multicolumn{2}{|c|}{0.156} & \multicolumn{2}{|c|}{0.312} & \multicolumn{2}{c}{0.625} \\
\hline $\begin{array}{c}\text { Temperature } \\
\text { of } \\
\begin{array}{c}\text { polymerisation } \\
\left({ }^{\circ} \mathrm{C}\right)\end{array}\end{array}$ & $\begin{array}{c}T_{\mathrm{m}} \\
\left({ }^{\circ} \mathrm{C}\right)\end{array}$ & $\begin{array}{c}T_{\mathrm{m}} \\
\left({ }^{\circ} \mathrm{C}\right)\end{array}$ & $\begin{array}{c}\text { Incorporation } \\
(\%)\end{array}$ & $\begin{array}{c}T_{\mathrm{m}} \\
\left({ }^{\circ} \mathrm{C}\right)\end{array}$ & $\begin{array}{c}\text { Incorporation } \\
(\%)\end{array}$ & $\begin{array}{c}T_{\mathrm{m}} \\
\left({ }^{\circ} \mathrm{C}\right)\end{array}$ & $\begin{array}{c}\text { Incorporation } \\
(\%)\end{array}$ \\
\hline 30 & 135 & 126 & - & 123 & - & 114 & \\
40 & 135 & 124 & - & 119 & - & 112 & 2.0 \\
50 & 136 & 125 & - & 120 & - & 114 & 2.2 \\
60 & 136 & 123 & - & 116 & - & 115 & 2.1 \\
70 & 138 & 125 & 0.6 & 122 & 1.0 & 122 & 2.1 \\
80 & 136 & 123 & - & 119 & - & 122 & 2.3 \\
90 & 134 & 126 & - & 122 & - & 118 & 2.6
\end{tabular}


Table 2.4. Polymer molecular weights $\left(M_{\mathrm{w}}\right)$ and molecular weight distributions $\left(M_{\mathrm{w}} / M_{\mathrm{n}}\right)$ of the polymers produced. (Co)polymerisation conditions: $10 \mathrm{mg}$ sMAO- ${ }^{\mathrm{Me}_{2}} \mathrm{SB}\left({ }^{t \mathrm{Bu}} \mathrm{N}, \mathrm{I}^{*}\right) \mathrm{TiCl}_{2}, 2$ bar ethylene, $0,0.156,0.312$ or $0.625 \mathrm{~mL}$ 1-hexene, $50 \mathrm{~mL}$ hexane, $150 \mathrm{mg}$ TiBA and 30 minutes.

\begin{tabular}{c|cc|cc|cc|cc}
$\begin{array}{c}\text { Vol. 1-hexene } \\
\text { added (mL) }\end{array}$ & \multicolumn{2}{|c|}{0} & \multicolumn{2}{|c|}{0.156} & \multicolumn{2}{c|}{0.312} & \multicolumn{2}{c}{0.625} \\
\hline $\begin{array}{c}\text { Temperature } \\
\text { of } \\
\begin{array}{c}\text { polymerisation } \\
\left({ }^{\circ} \mathrm{C}\right)\end{array}\end{array}$ & $\begin{array}{c}M_{\mathrm{w}} \\
(\mathrm{kDa})\end{array}$ & $M_{\mathrm{w}} / M_{\mathrm{n}}$ & $\begin{array}{c}M_{\mathrm{w}} \\
(\mathrm{kDa})\end{array}$ & $M_{\mathrm{w}} / M_{\mathrm{n}}$ & $\begin{array}{c}M_{\mathrm{w}} \\
(\mathrm{kDa})\end{array}$ & $M_{\mathrm{w}} / M_{\mathrm{n}}$ & $\begin{array}{c}M_{\mathrm{w}} \\
(\mathrm{kDa})\end{array}$ & $M_{\mathrm{w}} / M_{\mathrm{n}}$ \\
\hline 30 & 2313 & 4.2 & 1291 & 2.8 & 1133 & 3.1 & 894 & 3.0 \\
40 & 2197 & 3.9 & 856 & 2.8 & 781 & 2.8 & 695 & 2.7 \\
50 & 1175 & 4.1 & 740 & 2.8 & 700 & 2.8 & 393 & 2.8 \\
60 & 1063 & 4.4 & 637 & 3.0 & 499 & 3.1 & 203 & 2.7 \\
70 & 414 & 6.6 & 313 & 3.0 & 213 & 3.2 & 95 & 3.0 \\
80 & 282 & 6.8 & 294 & 3.6 & 243 & 3.1 & 95 & 4.1 \\
90 & 172 & 6.7 & 87 & 3.7 & 49 & 3.5 & 51 & 3.4
\end{tabular}

Large decreases in polymer molecular weights were observed with addition of 1-hexene. At $70{ }^{\circ} \mathrm{C}$, molecular weights decrease from $414 \mathrm{kDa}$ for homopolymerisation to $95 \mathrm{kDa}$ addition of $0.625 \mathrm{~mL}$ of 1-hexene (Table 2.4). This effect has been observed in the literature, with the molecular weight decrease resulting from frequent chain termination following addition of 1-hexene and chain transfer to 1-hexene monomers. Klosin and co-workers have undertaken work to negate this molecular weight decrease by addition of heteroatom substituents to the indenyl ligand..$^{9,72,104}$

Three other catalysts, sMAO- ${ }^{\mathrm{Me}, \operatorname{Pr}} \mathrm{SB}\left({ }^{t \mathrm{Bu}} \mathrm{N}, \mathrm{I}^{*}\right) \mathrm{TiCl}_{2}, \quad$ sMAO- ${ }^{\mathrm{Me}_{2}} \mathrm{SB}\left({ }^{t-\mathrm{Bu}} \mathrm{N},{ }^{3-\mathrm{Et}} \mathrm{I}^{*}\right) \mathrm{TiCl}_{2}$, and sMAO- ${ }^{\mathrm{Me}_{2}} \mathrm{SB}\left({ }^{t \mathrm{Bu}} \mathrm{N}, \mathrm{I}^{*}\right) \mathrm{Ti}\left(\mathrm{CH}_{2} \mathrm{Ph}\right){ }_{2}$, and an industrial standard $\mathrm{sMAO}-{ }^{\mathrm{Me}} 2 \mathrm{SB}\left({ }^{t \mathrm{Bu}} \mathrm{N}, \mathrm{Cp} *\right) \mathrm{TiCl}_{2}$ were also tested for ethylene/1-hexene copolymerisation at $70{ }^{\circ} \mathrm{C}$ under the previously described conditions. As can be seen in Figure 2.11, with the exception of sMAO- ${ }^{\mathrm{Me}_{2}} \mathrm{SB}\left({ }^{t \mathrm{Bu}} \mathrm{N}, \mathrm{I}^{*}\right) \mathrm{TiCl}_{2}$, copolymerisation activities decrease relative to homopolymerisation, and typically the maximum activities for copolymerisations are seen for addition of the largest amount of 1 -hexene $(0.625 \mathrm{~mL})$. Copolymerisation activities similarly 
decrease for sMAO- ${ }^{\mathrm{Me},{ }^{\mathrm{Pr}}} \mathrm{SB}\left({ }^{t \mathrm{Bu}} \mathrm{N}, \mathrm{I}^{*}\right) \mathrm{TiCl}_{2}$ and $\mathrm{sMAO}-{ }^{\mathrm{Me}}{ }_{2} \mathrm{SB}\left({ }^{t \mathrm{Bu}} \mathrm{N},{ }^{3-\mathrm{Et}}{ }^{*}\right) \mathrm{TiCl}_{2}$ relative to homopolymerisation. Temperature variation of ethylene homopolymerisation has shown that both complexes exhibit much greater decreases in polymerisation activity sMAO- $\left.{ }^{\mathrm{Me}_{2}} \mathrm{SB}^{t \mathrm{Bu}}{ }^{\mathrm{N}}, \mathrm{I}^{*}\right) \mathrm{TiCl}_{2} \quad\left(4138\right.$ to $3038 \mathrm{~kg} \mathrm{PE} / \mathrm{mol}_{\mathrm{Ti}} / \mathrm{h} / \mathrm{bar} \quad(27 \%)$ and 3593 to $2698 \mathrm{~kg}_{\mathrm{PE}} / \mathrm{mol}_{\mathrm{Ti}} / \mathrm{h} / \mathrm{bar}(25 \%)$ respectively compared with 3524 to $2981 \mathrm{~kg}_{\mathrm{PE}} / \mathrm{mol}_{\mathrm{Ti}} / \mathrm{h} / \mathrm{bar}(15 \%)$ from 70 to $\left.80{ }^{\circ} \mathrm{C}\right)$.

sMAO- ${ }^{\mathrm{Me}_{2}} \mathrm{SB}\left({ }^{t \mathrm{Bu}} \mathrm{N}, \mathrm{I}^{*}\right) \mathrm{Ti}\left(\mathrm{CH}_{2} \mathrm{Ph}\right)_{2}$ complex is less thermally stable than sMAO- ${ }^{\mathrm{Me}_{2}}{ }_{2} \mathrm{SB}\left({ }^{t \mathrm{Bu}} \mathrm{N}, \mathrm{I}^{*}\right) \mathrm{TiCl}_{2}$. A $44 \%$ decrease is seen in the copolymerisation for

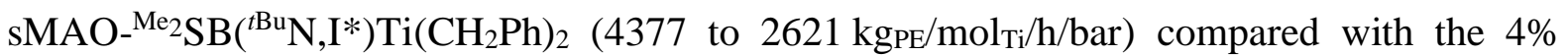
increase in activity for sMAO- $\left.{ }^{\mathrm{Me}_{2}} \mathrm{SB}{ }^{\mathrm{tBu}} \mathrm{N}, \mathrm{I} *\right) \mathrm{TiCl}_{2}\left(3443\right.$ to $3602 \mathrm{~kg} \mathrm{PE}_{\mathrm{PE}} / \mathrm{mol}_{\mathrm{Ti}} / \mathrm{h} / \mathrm{bar}$ ) on addition of 0.156 mL 1-hexene (Figure 2.11).

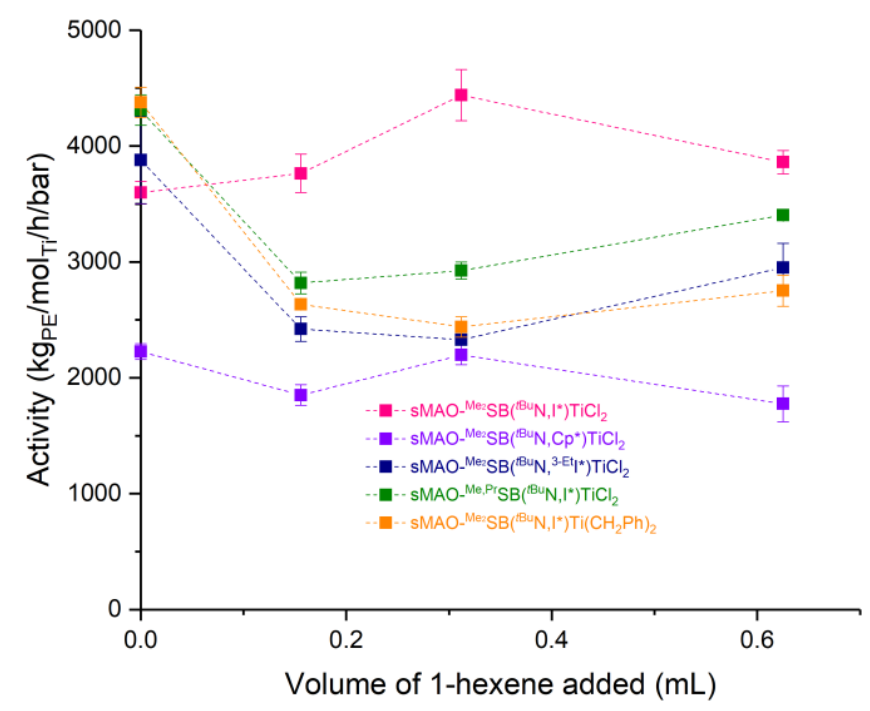

Figure 2.11. Ethylene/1-hexene copolymerisation activities. (Co)polymerisation conditions: $10 \mathrm{mg}$ catalyst, 2 bar ethylene, $0,0.156,0.312$ or $0.625 \mathrm{~mL}$ 1-hexene, $50 \mathrm{~mL}$ hexane, $150 \mathrm{mg}$ TiBA and 30 minutes.

This effect can also be seen in the two uptake rate plots (Figures S3.1 and S3.6), with the uptake rate plots remaining approximately constant for the duration of the polymerisations in the case of the dichloride complex, whilst the dibenzyl complex sees large decreases in uptake rates for 
the copolymerisations, while the homopolymerisation uptake remains approximately constant through the reaction. 1-hexene incorporation levels have been calculated for all of the catalysts for the copolymerisation with $0.625 \mathrm{~mL}$ of 1 -hexene, and the melting points determined by DSC (Table 2.5).

Table 2.5. Polymer melt temperatures $\left(T_{\mathrm{m}}\right)$, and 1-hexene incorporation levels for the catalysts:

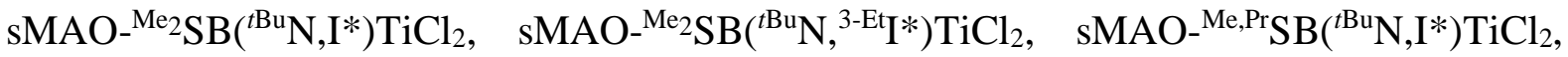
sMAO- ${ }_{2}{ }_{2} \mathrm{SB}\left({ }^{t \mathrm{Bu}} \mathrm{N}, \mathrm{I}^{*}\right) \mathrm{Ti}\left(\mathrm{CH}_{2} \mathrm{Ph}\right)_{2}$, and $\mathrm{sMAO}^{-{ }^{\mathrm{Me}}} 2 \mathrm{SB}\left({ }^{t \mathrm{Bu}} \mathrm{N}, \mathrm{Cp}^{*}\right) \mathrm{TiCl}_{2}$. (Co)polymerisation conditions: $10 \mathrm{mg}$ catalyst, 2 bar ethylene, $0,0.156,0.312$ or $0.625 \mathrm{~mL} 1$-hexene, $50 \mathrm{~mL}$ hexane, $150 \mathrm{mg}$ TiBA and 30 minutes.

\begin{tabular}{|c|c|c|c|c|c|c|}
\hline Volume of 1-hexene added (mL) & 0 & 0.156 & & 0.312 & & 0.625 \\
\hline Supported Complex & $\begin{array}{l}T_{\mathrm{m}} \\
\left({ }^{\circ} \mathrm{C}\right)\end{array}$ & $\begin{array}{c}T_{\mathrm{m}} \\
\left({ }^{\circ} \mathrm{C}\right)\end{array}$ & $\begin{array}{c}T_{\mathrm{m}} \\
\left({ }^{\circ} \mathrm{C}\right)\end{array}$ & $\begin{array}{c}\text { Incorporation } \\
(\%)\end{array}$ & $\begin{array}{c}T_{\mathrm{m}} \\
\left({ }^{\circ} \mathrm{C}\right)\end{array}$ & $\begin{array}{c}\text { Incorporation } \\
(\%)\end{array}$ \\
\hline sMAO- ${ }^{\mathrm{Me}_{2}} \mathrm{SB}\left({ }^{t \mathrm{Bu}} \mathrm{N}, \mathrm{I}^{*}\right) \mathrm{TiCl}_{2}$ & 138 & 125 & 122 & 1.0 & 122 & 2.1 \\
\hline sMAO- ${ }^{{ }^{M e}}{ }_{2} S B\left({ }^{t B u} \mathrm{~N},{ }^{3-E t} I^{*}\right) \mathrm{TiCl}_{2}$ & 133 & 122 & 117 & - & 114 & 2.4 \\
\hline sMAO- ${ }^{\mathrm{Me}, \mathrm{Pr}} \mathrm{SB}\left({ }^{t \mathrm{Bu}} \mathrm{N}, \mathrm{I}^{*}\right) \mathrm{TiCl}_{2}$ & 133 & 123 & 117 & - & 114 & 1.9 \\
\hline sMAO- ${ }^{{ }^{\mathrm{Me}}}{ }_{2} \mathrm{SB}\left({ }^{t \mathrm{Bu}} \mathrm{N}, \mathrm{I}^{*}\right) \mathrm{Ti}\left(\mathrm{CH}_{2} \mathrm{Ph}\right)_{2}$ & 133 & 122 & 117 & - & 114 & 2.2 \\
\hline sMAO- ${ }^{{ }^{\mathrm{Me}}}{ }_{2} \mathrm{SB}\left({ }^{t \mathrm{Bu}} \mathrm{N}, \mathrm{Cp}{ }^{*}\right) \mathrm{TiCl}_{2}$ & 134 & 120 & 117 & - & 107 & 3.5 \\
\hline
\end{tabular}

In the case of all catalysts, all polymer melt temperatures decrease, with increasing addition of 1-hexene comonomer. Incorporation levels for the permethylindenyl complexes (1.9-2.4\%) are lower than that of the permethylcyclopentadienyl ones (3.5\%). The incorporation levels are lower than typically observed for solution phase copolymerisation. ${ }^{72}$ Marks and Williams previously synthesised a range of constrained geometry complexes supported on MAOactivated sulfated alumina which showed lower levels of 1-hexene incorporation compared with solution phase reactions. ${ }^{73}$ These were attributed to mass transfer effects, where both the support and the propagating polymer chain cause diffusional resistance of the comonomer. ${ }^{74}$ 


\subsection{Slurry phase ethylene/styrene copolymerisation}

Five solid catalysts have been tested for the slurry phase ethylene/styrene copolymerisation. Copolymerisation activities decrease to a greater extent than was seen for ethylene/1-hexene copolymerisations (Figure 2.12). Mülhaupt et al. have previously reported similar results in solution phase using ${ }^{\mathrm{Me}_{2}} \mathrm{SB}\left({ }^{t \mathrm{Bu}} \mathrm{N}, \mathrm{Cp} *\right) \mathrm{TiCl}_{2} \cdot{ }^{105}$

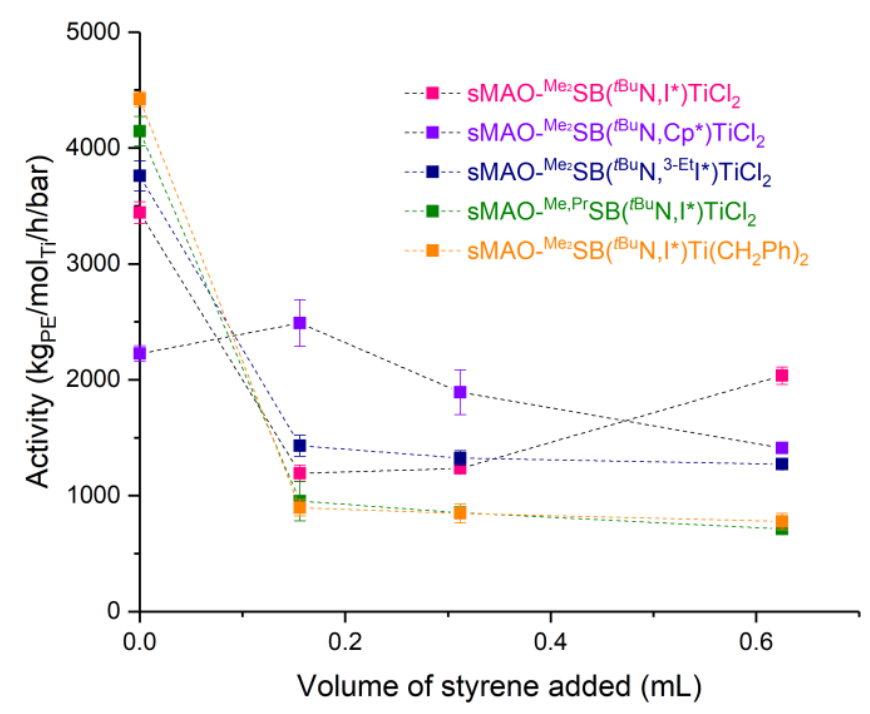

Figure 2.12. Ethylene/styrene copolymerisation activities. (Co)polymerisation conditions: $10 \mathrm{mg}$ catalyst, 2 bar ethylene, $0,0.156,0.312$ or $0.625 \mathrm{~mL}$ styrene, $50 \mathrm{~mL}$ hexane, $150 \mathrm{mg}$ TiBA and 30 minutes.

The decrease in copolymerisation activities are greater for the $\mathrm{I}^{*}$ complexes than the $\mathrm{Cp}^{*}$ complex, where the activity increases from 2227 to $2346 \mathrm{~kg} \mathrm{PE}_{\mathrm{mol}} / \mathrm{h} / \mathrm{bar}$ on addition of $0.156 \mathrm{~mL}$ of styrene followed by a decline in activities on addition of higher amounts of styrene. Klosin et al. reported that variation of the 3- and 4- positions of the Cp ring to phenyl groups resulted in higher copolymerisation activities than the $\mathrm{Cp}^{*}$ complex, $30500 \mathrm{~kg}_{\mathrm{PE}} / \mathrm{mmol}_{\mathrm{cat}}$ compared with $11870 \mathrm{~kg}_{\mathrm{PE}} / \mathrm{mmol}_{\mathrm{cat}}$, indicating the electronics of the ring substituents can greatly effect copolymerisation activities. ${ }^{9}$

For sMAO- ${ }^{\mathrm{Me}_{2}} \mathrm{SB}\left({ }^{t \mathrm{Bu}} \mathrm{N}, \mathrm{I}^{*}\right) \mathrm{TiCl}_{2}$, activities decrease from 3442 to $\sim 1200 \mathrm{~kg} \mathrm{PE} / \mathrm{mol}_{\mathrm{Ti}} / \mathrm{h} / \mathrm{bar}$ for additions of 0.156 and $0.312 \mathrm{~mL}$ of styrene, which then increases to $2036 \mathrm{~kg}_{\mathrm{PE}} / \mathrm{mol}_{\mathrm{Ti}} / \mathrm{h} / \mathrm{bar}$ with 
addition of $0.625 \mathrm{~mL}$. This is in contrast to the other $\mathrm{I}^{*}$ complexes where no increase in activities are seen for higher levels of styrene addition, but significant decreases in activity are seen in all cases. $\mathrm{SMAO}_{-}{ }^{\mathrm{Me}}{ }_{2} \mathrm{SB}\left({ }^{t \mathrm{Bu}} \mathrm{N},{ }^{3-\mathrm{Et}} \mathrm{I}^{*}\right) \mathrm{TiCl}_{2}$ decreases from 3759 to

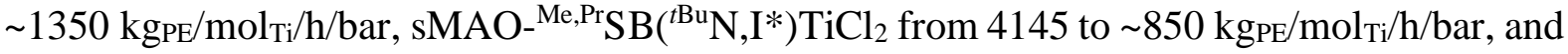
SMAO- ${ }^{\mathrm{Me}_{2}}{ }_{2 \mathrm{SB}}\left({ }^{t \mathrm{Bu}} \mathrm{N}, \mathrm{I}^{*}\right) \mathrm{Ti}\left(\mathrm{CH}_{2} \mathrm{Ph}\right)_{2}$ from 4380 to $\sim 850 \mathrm{~kg} \mathrm{PE}_{\mathrm{PE}} / \mathrm{mol}_{\mathrm{Ti}} / \mathrm{h} / \mathrm{bar}$. The polymer melt temperatures have been determined for the copolymers produced, and styrene incorporation levels determined by ${ }^{13} \mathrm{C}\left\{{ }^{1} \mathrm{H}\right\}$ NMR spectroscopy for the highest level of styrene addition (Table 2.6). The $\mathrm{Cp}^{*}$ complex shows higher levels of styrene incorporation relative to the I* complex (3.8\% compared with 1.6-2.5\%). Okuda and co-workers reported ${ }^{\mathrm{Me}}{ }_{2} \mathrm{SB}\left({ }^{t \mathrm{Bu}} \mathrm{N}, \mathrm{Cp} *\right) \mathrm{TiCl}_{2}$ incorporated $15.8 \mathrm{~mol} \%$ of styrene into the copolymer with a MAO cocatalyst, the fluorenyl analogue, ${ }^{\mathrm{Me}_{2}} \mathrm{SB}\left({ }^{t \mathrm{Bu}} \mathrm{N}, \mathrm{Flu}\right) \mathrm{TiCl}_{2}$, resulted in only $1.1 \mathrm{~mol} \%$ styrene incorporation and ${ }^{\mathrm{Me}_{2}} \mathrm{SB}\left({ }^{\mathrm{t} \mathrm{Bu}} \mathrm{N},{ }^{3-\mathrm{SiMe}_{3}} \mathrm{I}\right) \mathrm{TiCl}_{2}$ resulting in $5.7 \mathrm{~mol} \%$ incorporation under the same conditions. ${ }^{79}$ Klosin et al. showed greater levels of styrene incorporation, up to $30 \mathrm{~mol} \%$ incorporation from $11 \mathrm{~mol} \%$ using modified $\mathrm{Cp}^{*}$ complexes. $^{9}$

Table 2.6. Polymer melt temperatures $\left(T_{\mathrm{m}}\right)$, and styrene incorporation levels for the catalysts:

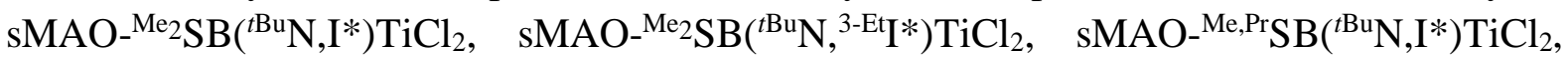

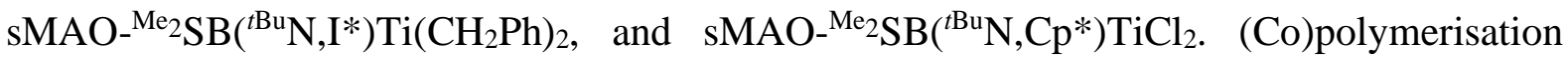
conditions: $10 \mathrm{mg}$ catalyst, 2 bar ethylene, $0,0.156,0.312$ or $0.625 \mathrm{~mL}$ styrene, $50 \mathrm{~mL}$ hexane, $150 \mathrm{mg}$ TiBA and 30 minutes.

\begin{tabular}{|c|c|c|c|c|c|}
\hline Volume of styrene added (mL) & 0 & 0.156 & 0.312 & & 0.625 \\
\hline Supported Complex & $\begin{array}{c}T_{\mathrm{m}} \\
\left({ }^{\circ} \mathrm{C}\right)\end{array}$ & $\begin{array}{c}T_{\mathrm{m}} \\
\left({ }^{\circ} \mathrm{C}\right)\end{array}$ & $\begin{array}{c}T_{\mathrm{m}} \\
\left({ }^{\circ} \mathrm{C}\right)\end{array}$ & $\begin{array}{c}T_{\mathrm{m}} \\
\left({ }^{\circ} \mathrm{C}\right)\end{array}$ & $\begin{array}{c}\text { Incorporation } \\
(\%)\end{array}$ \\
\hline sMAO- ${ }^{\mathrm{Me}_{2}} \mathrm{SB}\left({ }^{t \mathrm{Bu}} \mathrm{N}, \mathrm{I} *\right) \mathrm{TiCl}_{2}$ & 138 & 119 & 105 & 98 & 2.3 \\
\hline sMAO- ${ }^{{ }^{M e}}{ }_{2} \mathrm{SB}\left({ }^{t \mathrm{Bu}} \mathrm{N},{ }^{3-\mathrm{Et}}{ }^{*}\right) \mathrm{TiCl}_{2}$ & 133 & 120 & 114 & 107 & 2.5 \\
\hline sMAO- ${ }^{\mathrm{Me}, \mathrm{Pr}} \mathrm{SB}\left({ }^{\mathrm{tBu}} \mathrm{N}, \mathrm{I}^{*}\right) \mathrm{TiCl}_{2}$ & 133 & 122 & 119 & 113 & 1.6 \\
\hline sMAO- ${ }^{{ }^{M e}} 2 \operatorname{SB}\left({ }^{t \mathrm{Bu}} \mathrm{N}, \mathrm{I}^{*}\right) \mathrm{Ti}\left(\mathrm{CH}_{2} \mathrm{Ph}\right)_{2}$ & 133 & 120 & 116 & 110 & 1.8 \\
\hline sMAO- ${ }^{{ }^{M}}{ }_{2} \mathrm{SB}\left({ }^{t \mathrm{Bu}} \mathrm{N}, \mathrm{Cp} *\right) \mathrm{TiCl}_{2}$ & 134 & 115 & 109 & 98 & 3.8 \\
\hline
\end{tabular}


sMAO- ${ }^{\mathrm{Me}_{2}} \mathrm{SB}\left({ }^{t \mathrm{Bu}} \mathrm{N},{ }^{3-\mathrm{Et}} \mathrm{I}^{*}\right) \mathrm{TiCl}_{2}(2.5 \mathrm{~mol} \%)$ shows similar levels of comonomer incorporation than sMAO- ${ }^{{ }^{e}} 2 \mathrm{SB}\left({ }^{t \mathrm{Bu}} \mathrm{N}, \mathrm{I}^{*}\right) \mathrm{TiCl}_{2}(2.3 \mathrm{~mol} \%)$. Lower levels of styrene incorporation were observed for the sMAO- ${ }^{\mathrm{Me}, \mathrm{Pr}} \mathrm{SB}\left({ }^{t \mathrm{Bu}} \mathrm{N}, \mathrm{I}^{*}\right) \mathrm{TiCl}_{2}$ and $\mathrm{sMAO}-{ }^{\mathrm{Me}_{2}} \mathrm{SB}\left({ }^{t \mathrm{Bu}} \mathrm{N}, \mathrm{I}^{*}\right) \mathrm{Ti}\left(\mathrm{CH} \mathrm{C}_{2} \mathrm{Ph}\right)_{2}$ compared with the other complexes, which is also coupled with lower copolymerisation activities.

\section{Conclusions}

Eight new constrained geometry complexes were reported, with variation of the permethylindenyl fragment, ansa-bridge, amido group, metal centre and initiator groups. When supported on sMAO, these complexes, with the exception of ${ }^{\mathrm{Me}_{2}} \mathrm{SB}\left({ }^{t \mathrm{Bu}} \mathrm{N}, \mathrm{I}^{*}\right) \mathrm{ZrCl}_{2}$, have been shown to be efficient ethylene polymerisation catalysts. Variation of the initiator groups resulted in the highest enhancement in activities, with sMAO- ${ }^{{ }^{2}}{ }_{2} \mathrm{SB}\left({ }^{\mathrm{tBu}} \mathrm{N}, \mathrm{I}{ }^{*}\right) \mathrm{Ti}_{(}\left(\mathrm{CH}_{2} \mathrm{SiMe}_{3}\right)_{2}$ having a maximum activity of $7048 \mathrm{~kg} g_{P E} / \mathrm{mol}_{\mathrm{Ti}} / \mathrm{h} / \mathrm{bar}$.

The four complexes tested for copolymerisation showed good levels of 1-hexene incorporation, from 1.9 to $2.4 \mathrm{~mol} \%$, as is commonly expected for constrained geometry complexes. Variation of copolymerisation temperature with sMAO- ${ }^{\mathrm{Me}}{ }_{2} \mathrm{SB}\left({ }^{t \mathrm{Bu}} \mathrm{N}, \mathrm{I}^{*}\right) \mathrm{TiCl}_{2}$ showed that 1-hexene incorporation levels increase with higher copolymerisation temperature, and at $70{ }^{\circ} \mathrm{C}$ copolymerisation activities increased relative to homopolymerisation, the only time this was observed. Ethylene/styrene copolymerisations showed similar levels of incorporation, 1.6$2.5 \mathrm{~mol} \%$, with activities being hindered by addition of styrene relative to homopolymerisation. 


\section{Materials and Methods}

\subsection{Synthesis and characterisation of complexes}

\subsubsection{Synthesis of ${ }^{\mathrm{Me}_{2}} \mathrm{SB}\left({ }^{t \mathrm{Bu}} \mathrm{N}, \mathrm{I}^{*}\right) \mathrm{TiMe}_{2}$}

${ }^{\mathrm{Me}_{2}} \mathrm{SB}\left({ }^{\mathrm{tBu}} \mathrm{N}, \mathrm{I}^{*}\right) \mathrm{TiCl}_{2}(100 \mathrm{mg}, 0.22 \mathrm{mmol})$ was dissolved in toluene and cooled to $-78{ }^{\circ} \mathrm{C}$. A pre-cooled $\left(0^{\circ} \mathrm{C}\right) \mathrm{MeLi}$ solution $(0.31 \mathrm{~mL}, 1.6 \mathrm{M}, 0.49 \mathrm{mmol})$ was added dropwise over 5 minutes. The reaction was left to stir at $-78^{\circ} \mathrm{C}$ for 4 hours, during which a colour change from red to dark green was observed. The resultant mixture was left to warm to room temperature and the solvent removed in vacuo. The product was then extracted in pentane $(3 \mathrm{x}$ $10 \mathrm{~mL}$ ), and left at $-23{ }^{\circ} \mathrm{C}$ (18 hours) affording a green-yellow precipitate. The pentane solution was decanted and the solid dried in vacuo. The solid was then recrystallised in pentane to afford ${ }^{\mathrm{Me}}{ }_{2} \mathrm{SB}\left({ }^{t B u} \mathrm{~N}, \mathrm{I}^{*}\right) \mathrm{TiMe}_{2}$ as a green-yellow solid in $69 \%$ yield $(61 \mathrm{mg}, 0.15 \mathrm{mmol})$.

${ }^{1} \mathbf{H}$ NMR (C $\mathbf{C D}_{6}, 298$ K, 400 MHz): $\delta(\mathrm{ppm}) 2.47$ (3H, s, I*-Me), 2.45 (3H, s, I*-Me), 2.34 (3H, s, I*-Me), 2.11 (3H, s, I*-Me), 2.06 (3H, s, I*-Me), 2.03 (3H, s, I*-Me), 1.51 (9H, s, N- $\left.{ }^{t} \mathbf{B u}\right), 0.64$ (3H, s, Si-Me), 0.63 (3H, s, Si-Me), 0.59 (3H, s, Ti-Me) and -0.14 (3H, s, TiMe). ${ }^{13} \mathbf{C}\left\{{ }^{1} \mathbf{H}\right\}$ NMR $\left(\mathbf{C}_{6} \mathbf{D}_{6}, 298 \mathbf{~ K}, 125\right.$ MHz): $\delta(p p m) 142.18\left(\mathbf{I}^{*}\right), 135.76\left(\mathbf{I}^{*}\right), 133.72\left(\mathbf{I}^{*}\right)$, $132.82\left(\mathbf{I}^{*}\right), 131.62\left(\mathbf{I}^{*}\right), 130.04\left(\mathbf{I}^{*}\right), 129.91\left(\mathbf{I}^{*}\right), 122.82\left(\mathbf{I}^{*}\right), 88.91\left(\mathbf{I}^{*}\right), 57.79(\mathrm{~N}-\mathbf{C M e})$, 53.43 (Ti-Me), 52.20 (Ti-Me), 34.71 (C-Me) $), 21.45$ (I*-Me), 17.03 (I*-Me), 17.03 (I*-Me), 16.33 (I*-Me), 16.15 (I*-Me), 15.36 (I*-Me), 9.33 (Si-Me) and 8.44 (Si-Me). CHN Analysis (\%): Expected: C 68.12, H 9.69, N 3.45. Found: C 68.54, H 10.07, N 3.33. CCDC: 1966405.

\subsubsection{Synthesis of ${ }^{\mathrm{Me}}{ }_{2} \mathrm{SB}\left({ }^{t B u} \mathrm{~N}, I^{*}\right) \mathrm{Ti}\left(\mathrm{CH}_{2} \mathrm{SiMe}_{3}\right)_{2}$}

${ }^{{ }^{\mathrm{Ne}}} 2 \mathrm{SB}\left({ }^{t \mathrm{Bu}} \mathrm{N}, \mathrm{I}^{*}\right) \mathrm{TiCl}_{2} \quad(100 \mathrm{mg}, 0.22 \mathrm{mmol})$ and $\mathrm{LiCH}_{2} \mathrm{SiMe}_{3}(42.2 \mathrm{mg}, 0.45 \mathrm{mmol})$ were cooled to $5{ }^{\circ} \mathrm{C}$, and benzene was added. The orange-brown reaction mixture was allowed to warm to room temperature and stirred for 20 hours. The resultant mixture was filtered, dried in 
vacuo, and the product extracted in pentane $(3 \times 5 \mathrm{~mL})$. The solution was left at $-20^{\circ} \mathrm{C}$ (18 hours) affording a bright orange precipitate. The pentane solution was decanted and the solid dried in vacuo to afford ${ }^{\mathrm{Me}_{2}} \mathrm{SB}\left({ }^{\mathrm{tBu}} \mathrm{N}, \mathrm{I}^{*}\right) \mathrm{Ti}\left(\mathrm{CH}_{2} \mathrm{SiMe}_{3}\right)_{2}$ in $57 \%$ yield $(141 \mathrm{mg}, 0.26 \mathrm{mmol})$. A second crop of orange crystals suitable for a single crystal X-ray diffraction study were grown from the pentane filtrate at $-23^{\circ} \mathrm{C}$.

${ }^{1}$ H NMR (C ${ }_{6} D_{6}, 298$ K, 400 MHz): $\delta(\mathrm{ppm}) 2.56\left(3 \mathrm{H}, \mathrm{s}, \mathrm{I}^{*}-\mathrm{Me}\right), 2.55\left(3 \mathrm{H}, \mathrm{s}, \mathrm{I}^{*}-\mathrm{Me}\right)$, $2.36\left(3 \mathrm{H}, \mathrm{s}, \mathrm{I}^{*}-\mathrm{Me}\right), 2.17$ (3H, s, I*-Me), 2.12 (3H, s, I*-Me), 2.08 (3H, s, I*-Me), 1.51 (9H, s, N- $\left.{ }^{t} \mathbf{B u}\right), 1.21\left(1 \mathrm{H} \mathrm{d},{ }^{2} J_{\mathrm{HH}}=11.0 \mathrm{~Hz}, \mathrm{Ti}-\mathrm{CH}_{2}-\mathrm{Si}\right), 0.98\left(1 \mathrm{H}, \mathrm{d},{ }^{2} J_{\mathrm{HH}}=11.0 \mathrm{~Hz} \mathrm{Ti}-\mathrm{CH}_{2}-\mathrm{Si}\right)$, $0.65\left(1 \mathrm{H}, \mathrm{d},{ }^{2} J_{\mathrm{HH}}=11.0 \mathrm{~Hz}, \mathrm{Ti}-\mathrm{CH}_{2}-\mathrm{Si}\right), 0.66\left(3 \mathrm{H}, \mathrm{s}, \mathrm{I}^{*} \mathrm{Si}-\mathrm{Me}\right), 0.63$ (3H, s, I*Si-Me), $0.25\left(9 \mathrm{H}, \mathrm{s}, \mathrm{CH}_{2} \mathrm{Si}-\mathrm{Me}_{3}\right), 0.02\left(9 \mathrm{H}, \mathrm{s}, \mathrm{CH}_{2} \mathrm{Si}-\mathrm{Me}_{3}\right)$ and $-0.87\left(1 \mathrm{H}, \mathrm{d},{ }^{2} J_{\mathrm{HH}}=11.0 \mathrm{~Hz}\right.$,

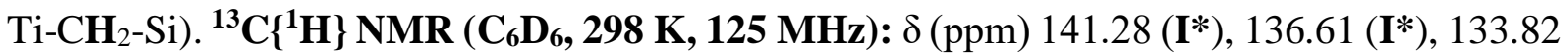
$\left(\mathbf{I}^{*}\right), \quad 133.27\left(\mathbf{I}^{*}\right), \quad 131.74 \quad\left(\mathbf{I}^{*}\right), \quad 130.25 \quad\left(\mathbf{I}^{*}\right), \quad 129.79 \quad\left(\mathbf{I}^{*}\right), \quad 123.29$ (I*), 88.34 (I*), $76.93\left(\mathrm{Ti}-\mathrm{CH}_{2}\right), \quad 68.67 \quad\left(\mathrm{Ti}-\mathrm{CH}_{2}\right), \quad 59.05 \quad\left(\mathrm{~N}-\mathrm{CMe}_{3}\right), \quad 34.33 \quad\left(\mathrm{C}-\mathrm{Me}_{3}\right), \quad 21.74\left(\mathrm{I}^{*}-\mathrm{Me}\right)$, 17.67 (I*-Me), 17.24 (I*-Me), 17.05 (I*-Me), 16.67 (I*-Me), 16.58 (I*-Me), 9.80 ( $\mathrm{Si}$-Me), 8.93 (Si-Me), 3.92 (Si-Me 3 ) and 2.91 (Si-Me $)$. CHN Analysis (\%): Expected: C 63.34, H 10.08, N 2.55. Found: C 64.78, H 10.35, N 2.48. CCDC: 1966406.

\subsubsection{Synthesis of ${ }^{\mathrm{Me}_{2}} \mathrm{SB}\left({ }^{(\mathrm{Bu}} \mathrm{N}, \mathrm{I}^{*}\right) \mathrm{Ti}\left(\mathrm{CH}_{2} \mathrm{Ph}\right)_{2}$}

${ }^{\mathrm{Me}_{2}} \mathrm{SB}\left({ }^{t \mathrm{Bu}} \mathrm{N}, \mathrm{I}^{*}\right) \mathrm{TiCl}_{2}(150 \mathrm{mg}, 0.34 \mathrm{mmol})$ and $\mathrm{KCH}_{2} \mathrm{Ph}(96.2 \mathrm{mg}, 0.74 \mathrm{mmol})$ were cooled to $5^{\circ} \mathrm{C}$, and benzene was added. The dark red reaction mixture was allowed to warm to room temperature and stirred for 20 hours. The resultant mixture was filtered then freeze-dried from benzene under vacuum. The dark red solid was washed with pre-cooled pentane at $-78{ }^{\circ} \mathrm{C}$ to afford ${ }^{\mathrm{Me} 2} \mathrm{SB}\left({ }^{\mathrm{B} u} \mathrm{~N}, \mathrm{I}^{*}\right) \mathrm{Ti}\left(\mathrm{CH}_{2} \mathrm{Ph}\right)_{2}$ as an orange solid in $58 \%$ yield $(105 \mathrm{mg}, 0.19 \mathrm{mmol})$.

${ }^{1} \mathbf{H}$ NMR (C6. $\left.\mathbf{D}_{\mathbf{6}}, 298 \mathrm{~K}, 400 \mathrm{MHz}\right): \delta(\mathrm{ppm}) 7.16\left(2 \mathrm{H}, \mathrm{t},{ }^{3} J_{\mathrm{HH}}=7.8 \mathrm{~Hz}, \mathrm{Ph}-\mathbf{H}_{\text {meta }}\right), 7.06(2 \mathrm{H}$, t, $\left.{ }^{3} J_{\mathrm{HH}}=7.5 \mathrm{~Hz}, \mathrm{Ph}-\mathbf{H}_{\text {meta }}\right), 6.94\left(2 \mathrm{H}, \mathrm{d}, \mathrm{Ph}-\mathbf{H}_{\text {ortho }},{ }^{3} J_{\mathrm{HH}}=7.5 \mathrm{~Hz}\right), 6.92\left(2 \mathrm{H}, \mathrm{t}, \mathrm{Ph}-\mathbf{H}_{\text {para }}\right.$, 
$\left.{ }^{3} J_{\mathrm{HH}}=7.0 \mathrm{~Hz}\right), 6.83\left(2 \mathrm{H}, \mathrm{t}, \mathrm{Ph}-\mathbf{H}_{\text {para }},{ }^{3} J_{\mathrm{HH}}=7.0 \mathrm{~Hz}\right), 6.71\left(2 \mathrm{H}, \mathrm{d}, \mathrm{Ph}-\mathbf{H}_{\text {ortho }},{ }^{3} J_{\mathrm{HH}}=7.0 \mathrm{~Hz}\right)$, $2.70\left(1 \mathrm{H}, \mathrm{d}, \mathrm{Ti}-\mathrm{CH}_{2}-\mathrm{Ph},{ }^{2} J_{\mathrm{HH}}=10.5 \mathrm{~Hz}\right), 2.45\left(3 \mathrm{H}, \mathrm{s}, \mathrm{I}^{*}-\mathrm{Me}\right), 2.40\left(1 \mathrm{H}, \mathrm{d}, \mathrm{Ti}-\mathrm{CH}_{2}-\mathrm{Ph}\right.$, $\left.{ }^{2} J_{\mathrm{HH}}=10.5 \mathrm{~Hz}\right), 2.24\left(3 \mathrm{H}, \mathrm{s}, \mathrm{I}^{*}-\mathrm{Me}\right), 2.20\left(3 \mathrm{H}, \mathrm{s}, \mathrm{I}^{*}-\mathrm{Me}\right), 2.10\left(3 \mathrm{H}, \mathrm{s}, \mathrm{I}^{*}-\mathrm{Me}\right), 1.97\left(3 \mathrm{H}, \mathrm{s}, \mathrm{I}^{*}-\right.$ Me), $1.90\left(3 \mathrm{H}, \mathrm{s}, \mathrm{I}^{*}-\mathrm{Me}\right), 1.59\left(1 \mathrm{H}, \mathrm{d}, \mathrm{Ti}-\mathrm{CH}_{2}-\mathrm{Ph},{ }^{2} \mathrm{~J}_{\mathrm{HH}}=10.5 \mathrm{~Hz}\right), 1.52\left(1 \mathrm{H}, \mathrm{d}, \mathrm{Ti}-\mathrm{CH} \mathbf{H}_{2}-\mathrm{Ph}\right.$, $\left.{ }^{2} J_{\mathrm{HH}}=10.5 \mathrm{~Hz}\right), 1.42\left(9 \mathrm{H}, \mathrm{s}, \mathrm{N}-{ }^{t} \mathbf{B u}\right)$ and $0.62(6 \mathrm{H}, \mathrm{Si}-\mathbf{M e}) .{ }^{13} \mathbf{C}\left\{{ }^{1} \mathbf{H}\right\}$ NMR $\left(\mathbf{C}_{6} \mathbf{D}_{6}, 298 \mathbf{~ K}\right.$, 125 MHz): $\delta$ (ppm) 150.75 (Ph), 150.20 (Ph), 141.98 (I*), $136.42\left(\mathbf{I}^{*}\right), 134.11\left(\mathbf{I}^{*}\right), 133.90$ (I*), $131.82\left(\mathbf{I}^{*}\right), 130.44\left(\mathbf{I}^{*}\right), 129.96\left(\mathbf{I}^{*}\right), 128.20(\mathbf{P h}), 128.10(\mathbf{P h}), 127.43(\mathbf{P h}), 127.35(\mathbf{P h})$, $125.56\left(\mathbf{I}^{*}\right), 122.43(\mathbf{P h}), 121.95(\mathbf{P h}), 91.09\left(\mathbf{I}^{*}\right), 85.01\left(\mathrm{Ti}-\mathbf{C H}_{2}\right), 81.75\left(\mathrm{Ti}_{-} \mathbf{C H}_{2}\right)$, $60.42\left(\mathrm{~N}-\mathrm{CMe}_{3}\right), 34.26$ (C-Me$), 21.14$ (I*-Me), 17.40 (I*-Me), 17.26 (I*-Me), 16.52 (I*-Me), 16.05 (I*-Me), 15.17 (I*-Me), 9.37 (Si-Me) and 8.53 (Si-Me). CHN Analysis (\%): Expected: C 75.38, H 8.49, N 2.51. Found: C 75.49, H 8.80, N 2.45.

\subsubsection{Synthesis of ${ }^{\mathrm{Me}_{2}} \mathrm{SB}\left({ }^{t \mathrm{Bu}} \mathrm{N}, \mathrm{I}^{*}\right) \mathrm{Ti}(\mathrm{Cl}) \mathrm{CH}_{2} \mathrm{SiMe}_{3}$}

${ }^{\mathrm{Me}_{2}} \mathrm{SB}\left({ }^{t \mathrm{Bu}} \mathrm{N}, \mathrm{I}^{*}\right) \mathrm{TiCl}_{2}(200 \mathrm{mg}, 0.45 \mathrm{mmol})$ was dissolved in $5 \mathrm{~mL}$ of benzene and cooled to $5{ }^{\circ} \mathrm{C}$. A solution of 1 equivalent of $\mathrm{LiCH}_{2} \mathrm{SiMe}_{3}(42.2 \mathrm{mg}, 0.45 \mathrm{mmol})$ in benzene was added dropwise over 45 minutes. The orange reaction mixture was allowed to warm to room temperature and stirred for 20 hours. The resultant mixture was filtered, dried in vacuo, and the product extracted in pentane $(3 \times 5 \mathrm{~mL})$. The solution was left at $-30^{\circ} \mathrm{C}(18$ hours $)$ affording ${ }^{\mathrm{Me}_{2}} \mathrm{SB}\left({ }^{t \mathrm{Bu}} \mathrm{N}, \mathrm{I}^{*}\right) \mathrm{Ti}(\mathrm{Cl}) \mathrm{CH}_{2} \mathrm{SiMe}_{3}$ as a bright orange precipitate in a $43 \%$ yield $(96 \mathrm{mg})$.

${ }^{1} \mathrm{H}_{\mathrm{NMR}}\left(\mathrm{C}_{\mathbf{6}} \mathrm{D}_{\mathbf{6}}, 298 \mathrm{~K}, 400 \mathrm{MHz}\right): \delta(\mathrm{ppm}) 2.54$ (3H, s, I*-Me), 2.53 (2H, s, I*-Me), 2.26 (3H, s, I*-Me), 2.18 (3H, s, I*-Me), 2.09 (3H, s, I*-Me), 2.07 (3H, s, I*-Me), 1.57 (1H, d, Ti-CH $\left.2-\mathrm{Si},{ }^{2} J_{\mathrm{HH}}=11.9 \mathrm{~Hz}\right), 1.51\left(9 \mathrm{H}, \mathrm{s}, \mathrm{N}^{t}{ }^{\mathrm{B} u}\right), 0.63(3 \mathrm{H}, \mathrm{s}, \mathrm{Si}-\mathrm{Me}), 0.51(3 \mathrm{H}, \mathrm{s}, \mathrm{Si}-\mathrm{Me})$, $0.10\left(9 \mathrm{H}, \mathrm{s}, \mathrm{CH}_{2} \mathrm{Si}-\mathbf{M e}_{3}\right)$ and $-0.97\left(1 \mathrm{H}, \mathrm{d}, \mathrm{Ti}-\mathrm{CH}_{2}-\mathrm{Si},{ }^{2} J_{\mathrm{HH}}=11.9 \mathrm{~Hz}\right) .{ }^{\mathbf{1 3}} \mathbf{C}\left\{{ }^{1} \mathbf{H}\right\} \mathbf{N M R}\left(\mathbf{C}_{6} \mathbf{D}_{6}\right.$, 298 K, 125 MHz): $\delta$ (ppm) $142.46\left(\mathbf{I}^{*}\right), 137.00$ (I*), 135.99 (I*), 134.25 (I*), 131.97 (I*), $130.94\left(\mathbf{I}^{*}\right), 130.55\left(\mathbf{I}^{*}\right), 95.84\left(\mathbf{I}^{*}\right), 73.14\left(\mathrm{Ti}^{*} \mathbf{C H}_{2}\right), 60.31\left(\mathrm{~N}-\mathbf{C M e}_{3}\right), 33.96\left(\mathrm{C}-\mathbf{M e}_{3}\right)$, 
21.47 (I*-Me), 17.83 (I*-Me), 17.11 (I*-Me), 16.59 (I*-Me), 16.56 (I*-Me), 16.56 (I*-Me), 8.51 ( $\mathrm{Si}-\mathrm{Me}), 7.90(\mathrm{Si}-\mathrm{Me})$ and $2.54(\mathrm{Si}-\mathrm{Me} \mathbf{e})$. One I* resonance is not observed, and is likely to be obscured by the solvent signals. CHN Analysis (\%): Expected: C 60.28, H 9.01, N 2.81. Found: C 60.14, H 9.01, N 2.83. CCDC: 1966407.

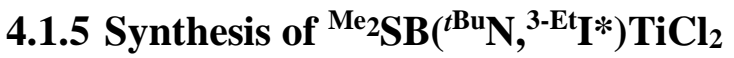

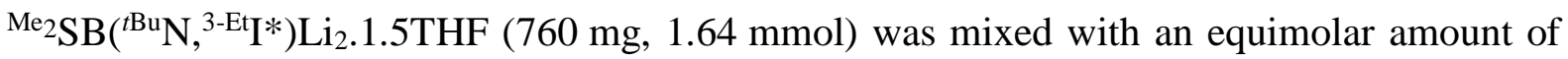
$\mathrm{TiCl}_{4} .2 \mathrm{THF}(630 \mathrm{mg})$ and cooled to $5{ }^{\circ} \mathrm{C}$. The mixture was dissolved in benzene, allowed to warm to $23{ }^{\circ} \mathrm{C}$ and stirred for 18 hours resulting in a dark red solution. The volatiles were removed under vacuum, and the product extracted in pentane as a dark red solution. The solution was concentrated and ${ }^{\mathrm{Me}_{2}} \mathrm{SB}\left({ }^{t B u} \mathrm{~N},{ }^{3-\mathrm{Et}} \mathrm{I}^{*}\right) \mathrm{TiCl}_{2}$ precipitated at $-20{ }^{\circ} \mathrm{C}$ as a dark red solid in a yield of $25 \%(0.19 \mathrm{~g}, 0.41 \mathrm{mmol})$.

${ }^{1} \mathbf{H}$ NMR $\left(\mathbf{C}_{6} \mathbf{D}_{\mathbf{6}}, 298 \mathrm{~K}, \mathbf{4 0 0} \mathbf{M H z}\right): \delta(\mathrm{ppm}) 3.34\left(1 \mathrm{H}, \mathrm{m}, \mathrm{I}^{*}-\mathrm{CH}_{2}-\mathrm{CH}_{3}{ }^{3} \mathrm{~J}_{\mathrm{H}-\mathrm{H}}=7.6 \mathrm{~Hz}\right), 3.03$ $\left(1 \mathrm{H}, \mathrm{m}, \mathrm{I}^{*}-\mathrm{CH}_{2}-\mathrm{CH}_{3}{ }^{3} J_{\mathrm{H}-\mathrm{H}}=7.6 \mathrm{~Hz}\right), 2.45\left(3 \mathrm{H}, \mathrm{s}, \mathrm{I}^{*}-\mathrm{Me}\right), 2.35\left(3 \mathrm{H}, \mathrm{s}, \mathrm{I}^{*}-\mathrm{Me}\right), 2.21(3 \mathrm{H}, \mathrm{s}$, I*-Me), $2.08\left(3 \mathrm{H}\right.$, s, I*-Me), $2.03\left(3 \mathrm{H}, \mathrm{s}, \mathrm{I}^{*}-\mathbf{M e}\right), 1.41\left(9 \mathrm{H}, \mathrm{s}, \mathrm{N}^{t} \mathbf{B u}\right), 0.92(3 \mathrm{H}, \mathrm{dd}$, $\left.\mathrm{I}^{*}-\mathrm{CH}_{2}-\mathbf{C H}_{3},{ }^{3} \mathrm{~J}_{\mathrm{H}-\mathrm{H}}=7.6 \mathrm{~Hz}\right), 0.63(3 \mathrm{H}, \mathrm{s}, \mathrm{Si}-\mathrm{Me})$ and $0.59(3 \mathrm{H}, \mathrm{s}, \mathrm{Si}-\mathrm{Me}) .{ }^{{ }^{13} \mathbf{C}\left\{{ }^{1} \mathbf{H}\right\}} \mathbf{N M R}$ (C $\left.\mathbf{C}_{6} \mathbf{D}_{6}, 298 \mathrm{~K}, 125 \mathrm{MHz}\right): \delta(\mathrm{ppm}) 145.71\left(\mathbf{I}^{*}\right), 139.70$ (I*), 137.69 (I*), 136.38 (I*), 131.59 (I*), $131.37\left(\mathbf{I}^{*}\right), 130.38\left(\mathbf{I}^{*}\right), 129.25\left(\mathbf{I}^{*}\right), 96.64\left(\mathbf{I}^{*}-\mathrm{Si}\right), 62.02\left(\mathrm{~N}-\mathbf{C}-\left(\mathrm{CH}_{3}\right)_{3}\right), 32.80(\mathrm{~N}-\mathrm{C}-$ $\left.\left(\mathbf{C H}_{3}\right)_{3}\right), 23.71\left(\mathrm{I}^{*}-\mathbf{C H}_{2}-\mathrm{CH}_{3}\right), 21.65$ (I*-Me), 17.30 (I*-Me), 16.66 (I*-Me), 16.37 (I*-Me), 16.22 (I*-Me), $15.04\left(\mathrm{I}^{*}-\mathrm{CH}_{2}-\mathbf{C H}_{3}\right), 8.21(\mathrm{Si}-\mathrm{Me})$ and 7.65 ( $\left.\mathrm{Si}-\mathrm{Me}\right)$.

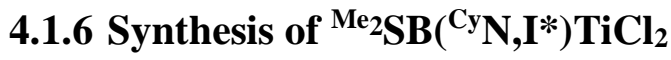

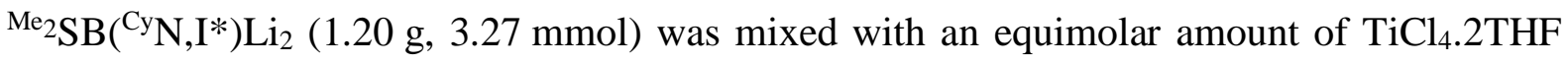
$(1.09 \mathrm{~g}, 3.27 \mathrm{mmol})$. The mixture was cooled in an ice bath and dissolved in benzene resulting in a dark red solution. The reaction mixture was allowed to warm to $23{ }^{\circ} \mathrm{C}$ and stirred for 18 hours. The volatiles were removed under vacuum, followed by extraction with pentane to 
yield a dark red solution. The solution was reduced and a dark red solid was precipitated at $-20{ }^{\circ} \mathrm{C}$ to afford ${ }^{\mathrm{Me}_{2}} \mathrm{SB}\left({ }^{\mathrm{Cy}} \mathrm{N}, \mathrm{I}^{*}\right) \mathrm{TiCl}_{2}$ in a $14 \%$ isolated yield $(0.22 \mathrm{~g})$.

${ }^{1} \mathbf{H}_{\text {NMR }}\left(\mathbf{C}_{6} \mathbf{D}_{6}, 298\right.$ K, 500 MHz): $\delta(\mathrm{ppm}) 4.25\left(1 \mathrm{H}, \mathrm{m}, \mathrm{N}-\mathrm{CyH} \mathbf{H}_{\mathrm{ipso}}\right), 2.55$ (3H, s, I*-Me), 2.42 (3H, s, I*-Me), 2.36 (3H, s, I*-Me), 2.22 (3H, s, I*-Me), 2.13 (1H, m, N-CyHortho), 2.07 (3H, s, I*-Me), 2.02 (3H, s, I*-Me), 1.99 (1H, m, N-CyHortho), 1.64 (1H, m, N-CyH meta $), 1.56$ (1H, m, N-CyH $\left.\mathbf{H}_{\text {meta }}\right), 1.43\left(1 \mathrm{H}, \mathrm{m}, \mathrm{N}-\mathrm{CyH} \mathbf{H a r a}_{\text {pa }}\right), 1.26\left(1 \mathrm{H}, \mathrm{m}, \mathrm{N}-\mathrm{CyH} \mathbf{H}_{\text {meta }}\right), 1.15(1 \mathrm{H}, \mathrm{m}$, N-CyH $\left.\mathbf{H}_{\text {meta }}\right), 0.87$ (1H, m, N-CyH $\left.\mathbf{H}_{\text {para }}\right), 1.02$ (1H, m, N-CyHortho), 0.94 (1H, m, N-CyHortho), $0.87\left(1 \mathrm{H}, \mathrm{m}, \mathrm{N}-\mathrm{Cy} \mathbf{H}_{\text {para }}\right), 0.60(3 \mathrm{H}, \mathrm{s}, \mathrm{Si}-\mathrm{Me})$ and $\left.0.54(3 \mathrm{H}, \mathrm{s}, \mathrm{Si}-\mathbf{M e}) .{ }^{{ }^{13}} \mathbf{C}^{1}{ }^{1} \mathbf{H}\right\}$ NMR $\left(\mathbf{C}_{6} \mathbf{D}_{\mathbf{6}}\right.$, 298 K, 125 MHz): $\delta(p p m) 146.40\left(\mathbf{I}^{*}\right), 140.25\left(\mathbf{I}^{*}\right), 137.19\left(\mathbf{I}^{*}\right), 135.82\left(\mathbf{I}^{*}\right), 131.65$ (I*), $131.56\left(\mathbf{I}^{*}\right), 131.09\left(\mathbf{I}^{*}\right), 131.01\left(\mathbf{I}^{*}\right), 93.78\left(\mathbf{I}^{*}-\mathrm{Si}\right), 64.94$ (N-Cy $\mathbf{\text { ipso }}$ ), 35.37 (N-Cy ortho), 35.00 (N-Cy ortho), 26.62 (N-Cy ${ }_{\text {meta }}$ ), 26.36 (N-Cy meta ), 26.10 (N-Cypara) 21.32 (I*-Me), 17.25 (I*Me), 17.12 (I*-Me), 17.04 (I*-Me), 16.91 (I*-Me), 16.52 (I*-Me), 7.38 (Si-Me) and 7.08 (Si-Me).

\subsubsection{Synthesis of ${ }^{\mathrm{Me}, \mathrm{Pr}} \mathrm{SB}\left({ }^{t \mathrm{Bu}} \mathrm{N}, \mathrm{I}^{*}\right) \mathrm{TiCl}_{2}$}

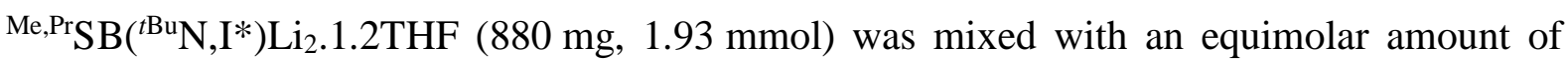
$\mathrm{TiCl}_{4} .2 \mathrm{THF}(640 \mathrm{mg})$. The mixture was cooled in an ice bath and dissolved in benzene resulting in a dark red solution. The reaction mixture was allowed to warm to $23{ }^{\circ} \mathrm{C}$ and stirred for 18 hours. The volatiles were removed under vacuum, followed by extraction into pentane to yield a dark red solution. The volatiles were once more removed under vacuum and the residue was dissolved in trimethylsilylether, concentrated and stored at $-20{ }^{\circ} \mathrm{C}$ to afford ${ }^{\mathrm{Me}, \mathrm{Pr}} \mathrm{SB}\left({ }^{t \mathrm{Bu}} \mathrm{N}, \mathrm{I}^{*}\right) \mathrm{TiCl}_{2}$ as a dark red solid which was isolated in a $20 \%$ yield $(180 \mathrm{mg})$.

${ }^{1}$ H NMR (C $\left.\mathbf{C}_{6} \mathbf{D}_{6}, 298 \mathrm{~K}, 500 \mathrm{MHz}\right)$ : Major Isomer (57\%): $\delta(\mathrm{ppm}) 2.56\left(3 \mathrm{H}, \mathrm{s}, \mathrm{I}^{*}-\mathrm{Me}\right), 2.55$ (3H, s, I*-Me), 2.44 (3H, s, I*-Me), 2.40 (3H, s, I*-Me), 2.39 (3H, s, I*-Me), 2.36 (3H, s, I*-Me), $1.74\left(2 \mathrm{H}, \mathrm{s}, \mathrm{Si}-\mathrm{CH}_{2}-\mathbf{C H}_{2}-\mathrm{CH}_{3}\right), 1.42\left(9 \mathrm{H}, \mathrm{s}, \mathrm{N}-{ }^{\mathrm{t}} \mathbf{B u}\right), 1.04$ (3H, t, Si-CH$\left.-\mathrm{CH}_{2}-\mathrm{CH}_{2}-\mathbf{C H}_{3}\right)$, 
$0.63(3 \mathrm{H}, \mathrm{s}, \mathrm{Si}-\mathrm{Me})$. Minor isomer (43\%): $\delta(\mathrm{ppm}) 2.19\left(3 \mathrm{H}, \mathrm{s}, \mathrm{I}^{*}-\mathrm{Me}\right), 2.17$ (3H, s, I*-Me), $2.08\left(3 \mathrm{H}, \mathrm{s}, \mathrm{I}^{*}-\mathrm{Me}\right), 2.07$ (3H, s, I*-Me), 2.06 (3H, s, I*-Me), 2.02 (3H, s, I*-Me), 1.52 (2H, s, $\left.\mathrm{Si}-\mathrm{CH}_{2}-\mathbf{C H}_{2}-\mathrm{CH}_{3}\right), 1.42\left(9 \mathrm{H}, \mathrm{s}, \mathrm{N}-{ }^{t} \mathbf{B u}\right), 1.10\left(3 \mathrm{H}, \mathrm{t}, \mathrm{Si}-\mathrm{CH}_{2}-\mathrm{CH}_{2}-\mathbf{C H}_{3}\right), 0.58$ (3H, s, Si-Me). ${ }^{13} \mathbf{C}\left\{{ }^{1} \mathbf{H}\right\}$ NMR $\left(\mathbf{C}_{6} \mathbf{D}_{6}, 298 \mathrm{~K}, 125 \mathrm{MHz}\right)$ : Major isomer (57\%): $\delta(\mathrm{ppm}) 146.39\left(\mathbf{I}^{*}\right), 140.68$ (I*), $137.96\left(\mathbf{I}^{*}\right), 136.96\left(\mathbf{I}^{*}\right), 134.68\left(\mathbf{I}^{*}\right), 131.58\left(\mathbf{I}^{*}\right), 131.51\left(\mathbf{I}^{*}\right), 130.52\left(\mathbf{I}^{*}\right), 96.30$ (I*-Si), $24.86\left(\mathrm{Si}_{-}-\mathrm{CH}_{2}-\mathbf{C H}_{2}-\mathrm{CH}_{3}\right), 21.54\left(\mathrm{I}^{*}-\mathrm{Me}\right), 19.88\left(\mathrm{I}^{*}-\mathrm{Me}\right), 18.35\left(\mathrm{Si}-\mathrm{CH}_{2}-\mathrm{CH}_{2}-\mathbf{C H}_{3}\right), 17.95$ (Si-CH $\left.2-\mathrm{CH}_{2}-\mathrm{CH}_{3}\right), 17.37$ (I*-Me), 17.30 (I*-Me), 16.66 (I*-Me), 16.57 (I*-Me), 6.47 (Si-Me). Minor isomer (43\%): $\delta(\mathrm{ppm}) 145.97\left(\mathbf{I}^{*}\right), 136.30\left(\mathbf{I}^{*}\right), 136.16\left(\mathbf{I}^{*}\right), 134.68\left(\mathbf{I}^{*}\right)$, $133.98\left(\mathbf{I}^{*}\right), 131.92\left(\mathbf{I}^{*}\right), 131.45\left(\mathbf{I}^{*}\right), 131.41\left(\mathbf{I}^{*}\right), 97.59\left(\mathbf{I}^{*}-\mathrm{Si}\right), 24.49\left(\mathrm{Si}_{-}-\mathrm{CH}_{2}-\mathbf{C H}_{2}-\mathrm{CH}_{3}\right)$, $18.37\left(\mathrm{Si}_{-}-\mathrm{CH}_{2}-\mathrm{CH}_{2}-\mathbf{C H}_{3}\right), 17.95\left(\mathrm{Si}-\mathbf{C H}_{2}-\mathrm{CH}_{2}-\mathrm{CH}_{3}\right), 17.14(\mathrm{I} *-\mathrm{Me}), 17.00$ (I*-Me), 16.98 (I*-Me), 16.91 (I*-Me), 16.54 (I*-Me), 16.48 (I*-Me) and 5.77 (Si-Me).

\subsubsection{Synthesis of ${ }^{\mathrm{Me}_{2} \mathrm{SB}\left({ }^{(\mathrm{Bu}} \mathrm{N}, \mathrm{I}^{*}\right) \mathrm{ZrCl}_{2}}$}

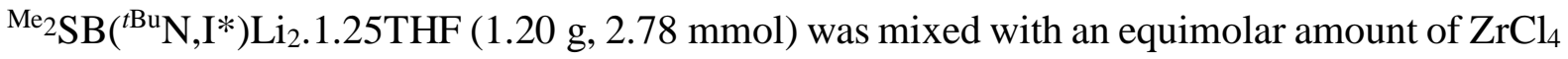
$(0.65 \mathrm{~g}, 2.78 \mathrm{mmol})$. The mixture was cooled in an ice bath and dissolved in benzene resulting in an orange/brown solution. The reaction mixture was allowed to warm to $23{ }^{\circ} \mathrm{C}$ and stirred for 18 hours. The volatiles were removed under vacuum and the product extracted in pentane as a dark orange solution. The solution was concentrated and stored at $-20{ }^{\circ} \mathrm{C}$ to afford

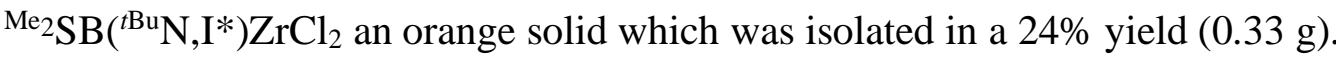

${ }^{1}$ H NMR (d6-benzene, 500 MHz): $\delta$ (ppm) 2.55 (3H, s, I*-Me), 2.42 (6H, s, I*-Me), 2.20 (3H, s, I*-Me), 2.08 (3H, s, I*-Me), 2.04 (3H, s, I*-Me), 1.31 (9H, s, N- ${ }^{*}$ Bu) and 0.69 (3H, s, Si-Me), $0.60(3 \mathrm{H}, \mathrm{s}, \mathrm{Si}-\mathrm{Me}) .{ }^{13} \mathbf{C}\left\{{ }^{1} \mathbf{H}\right\}$ NMR (d $\boldsymbol{d}_{\mathbf{6}}$-benzene, $\left.125 \mathrm{MHz}\right): \delta(\mathrm{ppm}) 143.15\left(\mathbf{I}^{*}\right), 137.04\left(\mathbf{I}^{*}\right)$, $135.65\left(\mathbf{I}^{*}\right), 134.98\left(\mathbf{I}^{*}\right), 130.08\left(\mathbf{I}^{*}\right), 129.05\left(\mathbf{I}^{*}\right), 128.36\left(\mathbf{I}^{*}\right), 124.05\left(\mathbf{I}^{*}\right), 88.67\left(\mathbf{I}^{*}\right.$-Si), 56.74 $\left(\mathrm{N}-\mathrm{C}-\left(\mathrm{CH}_{3}\right)_{3}\right), 33.32\left(\mathrm{~N}-\mathrm{C}-\left(\mathbf{C H}_{3}\right)_{3}\right), 21.44$ (I*-Me), 17.27 (I*-Me), 17.22 (I*-Me), 16.52 
(I*-Me), 16.30 (I*-Me), 15.86 (I*-Me), 9.97 (Si-Me), 8.96 (Si-Me). CHN Analysis (\%): Expected: C 51.29, H 7.17, N 2.85. Found: C 51.70, H 6.82, N 2.89.

\subsection{Synthesis of sMAO supported complexes}

$0.019 \mathrm{mmol}$ of complex and 200 equivalents of sMAO (250 mg, $3.78 \mathrm{mmol})$ were mixed in toluene at $25^{\circ} \mathrm{C}$, warmed to $60{ }^{\circ} \mathrm{C}$ and regularly swirled for 1 hour. The product was allowed to settle and the supernatant was decanted. The brown solid product was then dried under vacuum at room temperature.

SMAO- ${ }^{{ }_{2}}{ }_{2} \mathbf{S B}\left({ }^{t \mathrm{Bu}} \mathbf{N}, \mathbf{I}^{*}\right) \mathbf{T i}\left(\mathbf{C H}_{2} \mathbf{P h}\right)_{2}$. Isolated in a $77 \%$ yield. ${ }^{13} \mathbf{C}$ CP-MAS NMR (100.6 MHz): -7 (sMAO), 17 (I*Me), 21 (I*Me), 35 (I*Me), 53 (Ti-Me), 129 (sMAO), 132 (I*/Ph), $138\left(\right.$ I*/Ph) and 178 (sMAO). ${ }^{29}$ Si CP-MAS NMR (79.4 MHz): $-18 .{ }^{27} \mathrm{Al} \mathrm{DP-MAS}$ hahnecho NMR (104.2 MHz): 349, 211, 79, -85 and -243.

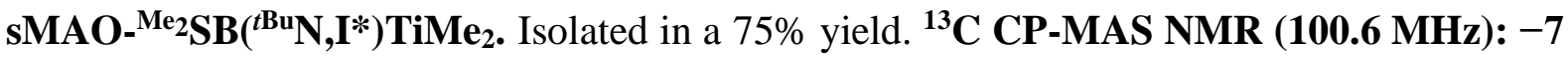
(sMAO), 17 (I*Me), 21 (I*Me), 35 (I*Me), 51 (Ti-Me), 129 (sMAO), 133 (I*), 138 (I*) and 178 (sMAO). ${ }^{29}$ Si CP-MAS NMR (79.4 MHz): -43. ${ }^{27}$ Al DP-MAS hahnecho NMR (104.2 MHz): 346, 208, 81, -84 and -241.

SMAO- $\left.{ }^{{ }_{2}}{ }_{2 B}{ }^{t{ }^{B u}} \mathbf{N}, I^{*}\right) \mathbf{T i}\left(\mathbf{C H}_{2} \mathrm{SiMe}_{3}\right)_{2}$. Isolated in a $71 \%$ yield. ${ }^{13} \mathrm{C}$ CP-MAS NMR (100.6 MHz): -7 (sMAO), 17 (I*Me), 21 (I*Me), 35 (I*Me), 53 (Ti-Me), 129 (sMAO), 133 (I*), 137 (I*) and 178 (sMAO). ${ }^{29}$ Si CP-MAS NMR (79.4 MHz): 0 and $-18 .{ }^{27}$ Al DP-MAS hahnecho NMR (104.2 MHz): 344, 205, 80, -85 and -242.

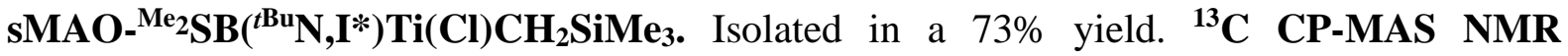
(100.6 MHz): -8 (sMAO), 17 (I*Me), 34 (I*Me), 51 (Ti-Me), 128 (sMAO), 132 (I*), 136 (I*) and 177 (sMAO). ${ }^{29}$ Si CP-MAS NMR (79.4 MHz): 0 and $-19 .{ }^{27}$ Al DP-MAS hahnecho NMR (104.2 MHz): 327, 182, -92 and -249 . 
SMAO- ${ }^{{ }_{2}}{ }_{2 B}\left({ }^{t B u} \mathbf{N}, C^{*}\right)$ TiCl 2 . Isolated in a $68 \%$ yield. ${ }^{13} \mathbf{C ~ C P - M A S ~ N M R ~ ( 1 0 0 . 6 ~ M H z ) : ~}-8$ (sMAO), 18 (Cp*Me), 32 (Cp*Me), 51 (Ti-Me), 128 (sMAO), 132 (Cp*), 135 (Cp*) and 179 (sMAO). ${ }^{29}$ Si CP-MAS NMR (79.4 MHz): $\quad-19 .{ }^{27}$ Al DP-MAS hahnecho NMR (104.2 MHz): 326, 184, -93 and -249.

SMAO- ${ }^{{ }_{2}}{ }_{2 B}\left({ }^{t B u} \mathbf{N},{ }^{3-E t} I^{*}\right)$ TiCl$_{2}$. Isolated in a 77\% yield. ${ }^{13} \mathrm{C}$ CP-MAS NMR (100.6 MHz): -8 (sMAO), 17 (I*Me), 22 (I*Me), 32 (I*Me), 51 (Ti-Me), 128 (sMAO), 131 (I*), 136 (I*) and 177 (SMAO). ${ }^{29}$ Si CP-MAS NMR (79.4 MHz): $-20 .{ }^{27}$ Al DP-MAS hahnecho NMR (104.2 MHz): 327, 183, -92, -249.

SMAO- ${ }^{\mathrm{Me}, \operatorname{Pr}} \mathbf{S B}\left({ }^{t{ }^{\mathbf{B u}}} \mathbf{N}, \mathbf{I}^{*}\right) \mathbf{T i C l}_{2}$. Isolated in a $85 \%$ yield.

SMAO- ${ }^{{ }_{2}}{ }_{\mathbf{S B}}\left({ }^{(\mathbf{B u}} \mathbf{N}, \mathbf{I}^{*}\right) \mathbf{Z r C l}_{2}$. Isolated in a $81 \%$ yield as a pale yellow solid.

\subsection{Slurry phase polymerisation of ethylene}

$150 \mathrm{mg}$ of triisobutylaluminium (TiBA) was mixed with $10 \mathrm{~mL}$ of hexane in a $150 \mathrm{~mL}$ ampoule. $10 \mathrm{mg}$ of supported catalyst was added, followed by $40 \mathrm{~mL}$ of hexane. The ampoule was allowed to warm up in an oil bath to the desired temperature after which it was opened up to 2 bar of ethylene while stirring and then left under a continuous flow for a specified time. The ampoule was then degassed and the mixture filtered. The polyethylene was then washed with pentane, dried and weighed.

\subsection{Slurry phase copolymerisation of ethylene/1-hexene and ethylene/styrene}

$150 \mathrm{mg}$ of triisobutylaluminium (TiBA) was mixed with $10 \mathrm{~mL}$ of hexane in a $150 \mathrm{~mL}$ ampoule. $10 \mathrm{mg}$ of supported catalyst was added, followed by $35 \mathrm{~mL}$ of hexane. In a sidearm, the desired amount of comonomer was added in $5 \mathrm{~mL}$ of hexane. The ampoule was allowed to warm up in an oil bath to the desired temperature after which it was opened up to 2 bar of ethylene while stirring, and the comonomer added in a single addition, and then left under a 
continuous flow for a specified time. The ampoule was then degassed and the mixture filtered.

The polyethylene was then washed with pentane, dried and weighed.

\section{Acknowledgment, Notes and References}

T. J. W., J.-C. B. and Z. R. T. (for a SCG Research Fellowship) would like to thank SCG Chemicals Co., Ltd. (Thailand) for funding and T. J. W. the EPRSC (EP/N509711/1) for financial support; Dr Jessica Lamb (University of Oxford) for Scanning Electron Microscope images; Dr Nicholas H. Rees (University of Oxford) for solid-state NMR spectroscopy experiments; Chemical Crystallography (University of Oxford) for the use of the diffractometers; Research Complex at Harwell for use of the Scanning Electron Microscope; Ms Liv Thobru (Norner AS, Norway) for GPC, and Prof. Charlotte Williams (University of Oxford) for use of the Differential Scanning Calorimeter.

1 J. C. Stevens, F. J. Timmers, D. R. Wilson, G. F. Schmidt, P. N. Nickias, R. K. Rosen, G. W. Knight, S. Y. Lai, 1991, EP0416815A2.

2 P. J. Shapiro, E. Bunel, W. P. Schaefer and J. E. Bercaw, Organometallics, 1990, 9, 867-869.

3 J. Okuda, Chem. Ber., 1990, 123, 1649-1651.

4 J. C. Stevens, 26. Insite ${ }^{T M}$ Catalysts Structure/Activity Relationships for Olefin Polymerization, Studies in Surface Science and Catalysis, Volume 89, 1994, 277-284.

5 H. Braunschweig and F. M. Breitling, Coord. Chem. Rev., 2006, 250, 2691-2720.

6 J. Cano and K. Kunz, J. Organomet. Chem., 2007, 692, 4411-4423.

7 F. Amor and J. Okuda, J. Organomet. Chem., 1996, 520, 245-248.

8 J. Okuda, F. J. Schattenmann, S. Wocadlo and W. Massa, Organometallics, 1995, 14, 789 795.

9 J. Klosin, P. P. Fontaine and R. Figueroa, Acc. Chem. Res., 2015, 48, 2004-2016.

10 B. Rhodes, J. C. W. Chien, J. S. Wood, A. Chandrasekaran and M. D. Rausch, Appl. Organomet. Chem., 2002, 16, 323-330.

11 A. Reb and H. G. Alt, J. Mol. Catal. A Chem., 2001, 174, 35-49.

12 H. G. Alt, A. Reb and K. Kundu, J. Organomet. Chem., 2001, 628, 211-221.

13 H. Braunschweig, F. M. Breitling, C. von Koblinski, A. J. P. White and D. J. Williams, Dalt. Trans., 2004, 938.

14 H. Braunschweig, F. M. Breitling, K. Radacki and F. Seeler, J. Organomet. Chem., 2005, 690, 5000-5005.

15 K. Kunz, G. Erker, S. Döring, R. Fröhlich and G. Kehr, J. Am. Chem. Soc., 2001, 123, 61816182.

16 K. Kunz, G. Erker, S. Döring, S. Bredeau, G. Kehr and R. Fröhlich, Organometallics, 2002, 21, 1031-1041.

17 V. V. Kotov, E. V. Avtomonov, J. Sundermeyer, K. Harms and D. A. Lemenovskii, Eur. J. Inorg. Chem., 2002, 2002, 678-691.

18 H. V. Rasika Dias, Z. Wang and S. G. Bott, J. Organomet. Chem., 1996, 508, 91-99.

19 Y. Mu, W. E. Piers, M.-A. MacDonald and M. J. Zaworotko, Can. J. Chem., 1995, 73, 2233 2238.

20 K. C. Hultzsch, T. P. Spaniol and J. Okuda, Angew. Chem. Int. Ed., 1999, 38, 227-230.

21 E. Kirillov, L. Toupet, C. W. Lehmann, A. Razavi and J.-F. Carpentier, Organometallics, 2003, 22, 4467-4479. 
J. Okuda, Dalt. Trans., 2003, 2367-2378.

P. T. Witte, A. Meetsma and B. Hessen, Organometallics, 1999, 18, 2944-2946.

W. Kaminsky, B. Hinrichs and D. Rehder, Polymer (Guildf)., 2002, 43, 7225-7229.

M. I. Alcalde, M. P. Gómez-Sal and P. Royo, Organometallics, 1999, 18, 546-554. 5284-5286.

W. A. Herrmann, W. Baratta and M. J. A. Morawietz, J. Organomet. Chem., 1995, 497, C4C6.

T.-F. Wang, C.-Y. Lai, C.-C. Hwu and Y.-S. Wen, Organometallics, 1997, 16, 1218-1223.

J. M. Pietryga, J. D. Gorden, C. L. B. Macdonald, A. Voigt, R. J. Wiacek and A. H. Cowley, J. Am. Chem. Soc., 2001, 123, 7713-7714.

J. M. Pietryga, J. N. Jones, L. A. Mullins, R. J. Wiacek and A. H. Cowley, Chem. Commun., 2003, 2072-2073.

R. J. Wiacek, C. L. B. Macdonald, J. N. Jones, J. M. Pietryga and A. H. Cowley, Chem. Commun., 2003, 430-431.

A. K. Hughes, S. M. B. Marsh, J. A. K. Howard and P. S. Ford, J. Organomet. Chem., 1997, 528, 195-198.

A. K. Hughes, A. Meetsma and J. H. Teuben, Organometallics, 1993, 12, 1936-1945.

Y.-X. Chen and T. J. Marks, Organometallics, 1997, 16, 3649-3657.

J. V. Lamb, J.-C. Buffet, Z. R. Turner and D. O'Hare, Polym. Chem., 2019, 10, 1386-1398.

G. Natta, Angew. Chem., 1956, 68, 393-403.

K. Ziegler, E. Holzkamp, H. Breil and H. Martin, Angew. Chem., 1955, 67, 426-426.

W. Kaminsky, A. Funck and H. Hähnsen, Dalt. Trans., 2009, 8803.

39 H. Sinn, W. Kaminsky, H.-J. Vollmer and R. Woldt, Angew. Chemie Int. Ed. English, 1980, 19, 390-392.

40 W. Kaminsky, Macromolecules, 2012, 45, 3289-3297.

41 F. Zaccaria, C. Zuccaccia, R. Cipullo, P. H. M. Budzelaar, A. Macchioni, V. Busico and C. Ehm, ACS Catal., 2019, 9, 2996-3010.

H. S. Zijlstra, A. Joshi, M. Linnolahti, S. Collins and J. S. McIndoe, Dalt. Trans., 2018, 47, 17291-17298.

H. S. Zijlstra, S. Collins and J. S. McIndoe, Chem. - A Eur. J., 2018, 24, 5506-5512. 4147.

E. V. Ramos-Fernández, A. Sepúlveda-Escribano and F. Rodríguez-Reinoso, Catal. Commun., 2008, 9, 1243-1246.

46 J.-C. Buffet, Z. R. Turner, R. T. Cooper and D. O'Hare, Polym. Chem., 2015, 6, 2493-2503.

47 P. A. Zapata, C. Belver, R. Quijada, P. Aranda and E. Ruiz-Hitzky, Appl. Catal. A Gen., 2013, 453, 142-150.

H. Rahiala, I. Beurroies, T. Eklund, K. Hakala, R. Gougeon, P. Trens and J. B. Rosenholm, J. Catal., 1999, 188, 14-23.

49 P. Wongwaiwattanakul and B. Jongsomjit, Catal. Commun., 2008, 10, 118-122.

50 J.-C. Buffet, T. A. Q. Arnold, Z. R. Turner, P. Angpanitcharoen and D. O'Hare, RSC Adv., 2015, 5, 87456-87464.

51 V. N. Panchenko, N. V. Semikolenova, I. G. Danilova, E. A. Paukshtis and V. A. Zakharov, J. Mol. Catal. A Chem., 1999, 142, 27-37.

52 E. Y.-X. Chen and T. J. Marks, Chem. Rev., 2000, 100, 1391-1434.

53 M. E. Z. Velthoen, A. Muñoz-Murillo, A. Bouhmadi, M. Cecius, S. Diefenbach and B. M. Weckhuysen, Macromolecules, 2018, 51, 343-355.

54 M. E. Z. Velthoen, J. M. Boereboom, R. E. Bulo and B. M. Weckhuysen, Catal. Today, 2019, 334, 223-230.

55 M. A. Bashir, V. Monteil, C. Boisson and T. F. L. McKenna, Macromol. Symp., 2016, 360, 61-68.

56 M. A. Bashir, T. Vancompernolle, R. M. Gauvin, L. Delevoye, N. Merle, V. Monteil, M. Taoufik, T. F. L. McKenna and C. Boisson, Catal. Sci. Technol., 2016, 6, 2962-2974.

57 E. Kaji, E. Yoshioka, 2010, WO2010055652. 
A. F. R. Kilpatrick, J.-C. Buffet, P. Nørby, N. H. Rees, N. P. Funnell, S. Sripothongnak and D. O'Hare, Chem. Mater., 2016, 28, 7444-7450.

J.-C. Buffet, Z. R. Turner and D. O'Hare, Chem. Commun., 2018, 54, 10970-10973.

D. O'Hare, J. C. Green, T. Marder, S. Collins, G. Stringer, A. K. Kakkar, N. Kaltsoyannis, A. Kuhn and R. Lewis, Organometallics, 1992, 11, 48-55.

P. Ransom, A. Ashley, A. Thompson and D. O'Hare, J. Organomet. Chem., 2009, 694, 10591068.

P. Ransom, A. E. Ashley, N. D. Brown, A. L. Thompson and D. O'Hare, Organometallics, 2011, 30, 800-814.

P. Ransom, T. A. Q. Arnold, A. L. Thompson, J. Buffet and D. O'Hare, Dalt. Trans., 2012, 41, $11267-11269$.

P. Angpanitcharoen, G. Hay, J.-C. Buffet, Z. R. Turner, T. A. Q. Arnold and D. O'Hare, Polyhedron, 2016, 116, 216-222.

T. A. Q. Arnold, J.-C. Buffet, Z. R. Turner and D. O'Hare, J. Organomet. Chem., 2015, 792, $55-65$.

J. V. Lamb, J.-C. Buffet, J. E. Matley, C. M. R. Wright, Z. R. Turner and D. O'Hare, Dalt. Trans., 2019, 48, 2510-2520. T. J. Williams, J.-C. Buffet, Z. R. Turner and D. O'Hare, Catal. Sci. Technol., 2018, 8, 54545461.

W. Kaminsky, Macromol. Chem. Phys., 1996, 197, 3907-3945.

M. Dankova and R. M. Waymouth, Macromolecules, 2003, 36, 3815-3820.

R. Quijada, J. Dupont, M. S. L. Miranda, R. B. Scipioni and G. B. Galland, Macromol. Chem. Phys., 1995, 196, 3991-4000.

J. Canich, G. Licciardi, 1991, US5057475A. Organometallics, 2001, 20, 2663-2665.

L. A. Williams and T. J. Marks, Organometallics, 2009, 28, 2053-2061. K. Czaja, L. A. Novokshonova and N. J. Kovaleva, Macromol. Chem. Phys., 1999, 200, $983-$ 988.

R. Mani and C. M. Burns, Macromolecules, 1991, 24, 5476-5477.

K. Soga, D. Lee and H. Yanagihara, Polym. Bull., 1988, 20.

K. Nomura, H. Okumura, T. Komatsu and N. Naga, Macromolecules, 2002, 35, 5388-5395.

K. Nomura, T. Komatsu and Y. Imanishi, Macromolecules, 2000, 33, 8122-8124. F. G. Sernetz, R. Mulhaupt, F. Amor, T. Eberle and J. Okuda, J. Polym. Sci. Part A Polym. Chem., 1997, 35, 1571-1578.

80 A.-S. Rodrigues and J.-F. Carpentier, Coord. Chem. Rev., 2008, 252, 2137-2154.

81 H. J. Bernstein and W. G. Schneider, Proc. R. Soc. London, Ser. A Math. Phys. Eng. Sci., 1956, 236, 515-528. Perez-Camacho, Macromolecules, 2017, 50, 8871-8884. I. M. Lee, W. J. Gauthier, J. M. Ball, B. Iyengar and S. Collins, Organometallics, 1992, 11, 2115-2122.

M. K. Mahanthappa and R. M. Waymouth, J. Am. Chem. Soc., 2001, 123, 12093-12094. 8940-8946.

88 M. Rahaman, M. A. Parvez, J. B. P. Soares and I. A. Hussein, Int. J. Polym. Sci., 2014, 2014, $1-10$.

89 W. E. Piers, P. J. Shapiro, E. E. Bunel and J. E. Bercaw, Synlett, 1990, 1990, 74-84.

90 H. G. Alt and A. Köppl, Chem. Rev., 2000, 100, 1205-1222.

91 J. A. Ewen, R. L. Jones, A. Razavi and J. D. Ferrara, J. Am. Chem. Soc., 1988, 110, 62556256.

92 H. G. Alt and R. Zenk, J. Organomet. Chem., 1996, 526, 295-301.

93 M. F. N. . Carvalho, K. Mach, A. . Dias, J. . Mano, M. . Marques, A. . Soares and A. J. . 
Pombeiro, Inorg. Chem. Commun., 2003, 6, 331-334.

94 P. Schertl and H. G. Alt, J. Organomet. Chem., 1999, 582, 328-337.

95 H. Juvaste, T. T. Pakkanen and E. I. Iiskola, Organometallics, 2000, 19, 1729-1733.

96 L. Fan, D. Harrison, T. K. Woo and T. Ziegler, Organometallics, 1995, 14, 2018-2026.

97 J. Suhm, M. J. Schneider and R. Mülhaupt, J. Polym. Sci. Part A Polym. Chem., 1997, 35, 735-740.

98 B. J. Banaszak, D. Lo, T. Widya, W. H. Ray, J. J. de Pablo, A. Novak and J. Kosek, Macromolecules, 2004, 37, 9139-9150.

99 A. Novak, M. Bobak, J. Kosek, B. J. Banaszak, D. Lo, T. Widya, W. Harmon Ray and J. J. de Pablo, J. Appl. Polym. Sci., 2006, 100, 1124-1136.

100 P. Starck, P. Lehmus and J. V. Seppälä, Polym. Eng. Sci., 1999, 39, 1444-1455.

101 M. D. E. F. V Marques, R. B. Tiosso and P. E. Mano, J. Mater. Sci. Eng. with Adv. Technol., 2011, 4, 149-173.

102 T. Wiedemann, G. Voit, A. Tchernook, P. Roesle, I. Göttker-Schnetmann and S. Mecking, $J$. Am. Chem. Soc., 2014, 136, 2078-2085.

103 K. Czaja and M. Bialek, Polimery, 2000, 45, 353-357.

104 Y. He, X. Qiu, J. Klosin, R. Cong, G. R. Roof and D. Redwine, Macromolecules, 2014, 47, 3782-3790.

105 F. G. Sernetz, R. Mülhaupt and R. M. Waymouth, Macromol. Chem. Phys., 1996, 197, 10711083.

The authors declare no conflict of interest. 